


\section{The legal framework and national policies for urban greenery and green values in urban areas}

A study of legislation and policy documents in the five Nordic countries and two European outlooks

By Johannes Lidmo, Ágúst Bogason and Eeva Turunen

NORDREGIO REPORT 2020:3 
The legal framework and national policies for urban greenery and green values in urban areas

A study of legislation and policy documents in the five Nordic countries and two European outlooks

Nordregio Report 2020:3

ISBN 978-91-87295-84-3

ISSN $1403-2503$

DOI: doi.org/10.6027/R2O2O:3.1403-2503

(C) Nordregio 2020

Nordregio

P.O. Box 1658

SE-111 86 Stockholm, Sweden

nordregio@nordregio.org

www.nordregio.org

www.norden.org

Analyses and text: Johannes Lidmo, Ágúst Bogason, and Eeva Turunen Contributors: Carmen Aalbers, Peter Schmitt and Anna Steidle

Coverphoto: Shutterstock

\section{Nordregio}

is a leading Nordic and European research centre for regional development and planning, established by the Nordic Council of Ministers in 1997. We conduct solution-oriented and applied research, addressing current issues from both a research perspective and the viewpoint of policymakers and practitioners. Operating at the international, national, regional and local levels, Nordregio's research covers a wide geographic scope, with an emphasis on the Nordic and Baltic Sea Regions, Europe and the Arctic.

\section{The Nordic co-operation}

Nordic co-operation is one of the world's most extensive forms of regional collaboration, involving Denmark, Finland, Iceland, Norway, Sweden, and the Faroe Islands, Greenland, and Åland. Nordic co-operation has firm traditions in politics, the economy, and culture. It plays an important role in European and international collaboration, and aims at creating a strong Nordic community in a strong Europe. Nordic co-operation seeks to safeguard Nordic and regional interests and principles in the global community. Common Nordic values help the region solidify its position as one of the world's most innovative and competitive.

\section{The Nordic Council of Ministers}

is a forum of co-operation between the Nordic governments. The Nordic Council of Ministers implements Nordic co-operation. The prime ministers have the overall responsibility. Its activities are co-ordinated by the Nordic ministers for co-operation, the Nordic Committee for co-operation and portfolio ministers. Founded in 1971.

\section{The Nordic Council}

is a forum for co-operation between the Nordic parliaments and governments. The Council consists of 87 parliamentarians from the Nordic countries. The Nordic Council takes policy initiative s and monitors Nordic co-operation. Founded in 1952. 


\section{Table of contents}

Summary

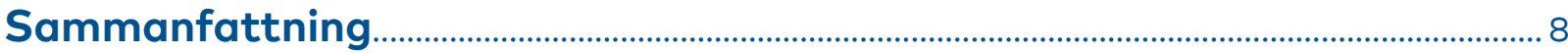

Planning for green qualities in the compact city ........................................................... 10

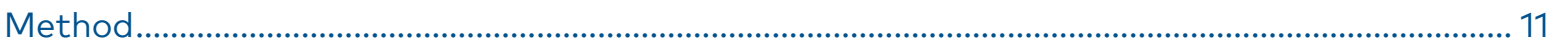

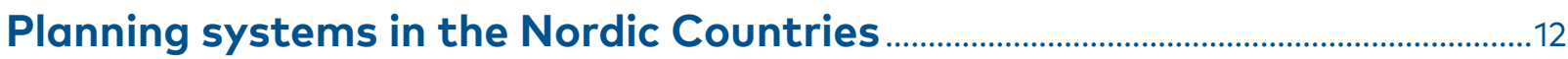

Legal framework and national policies....................................................................................15

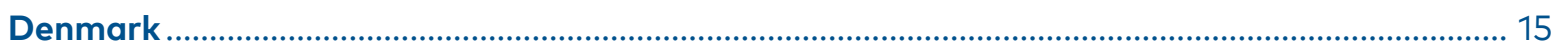

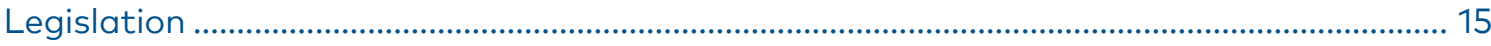

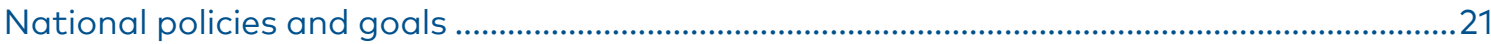

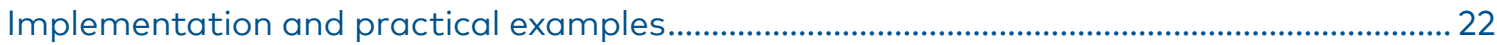

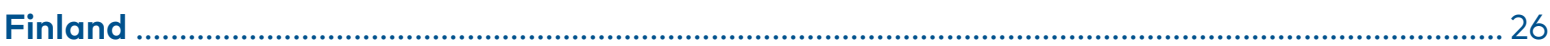

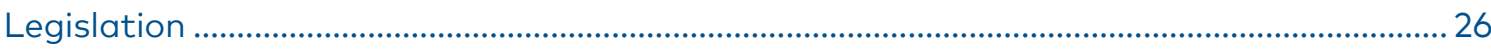

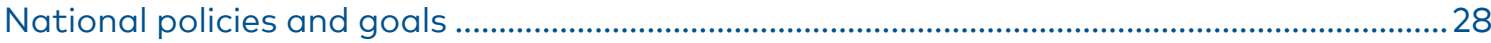

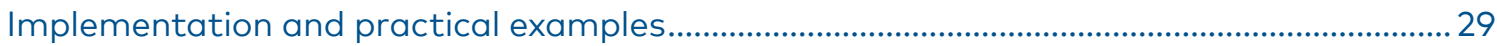

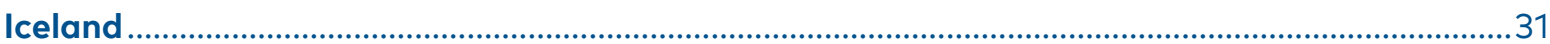

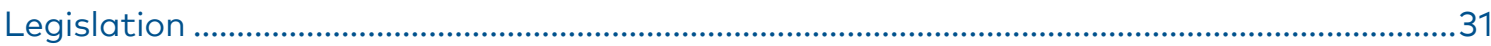

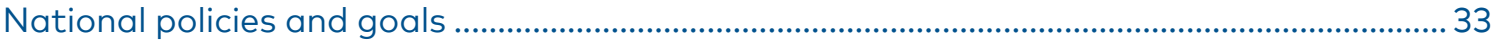

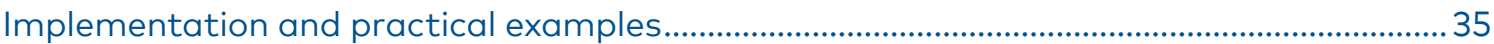

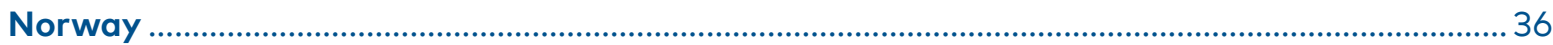

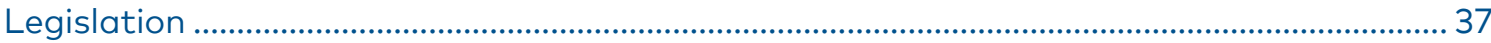

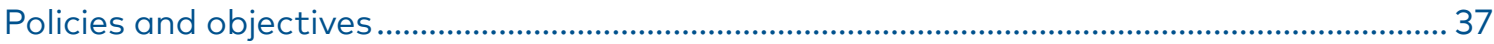

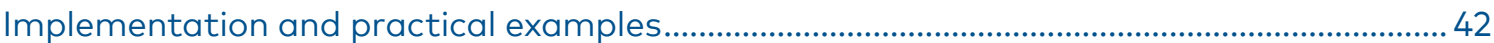

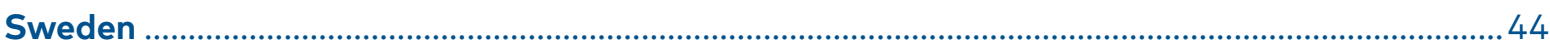

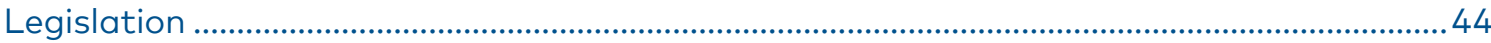

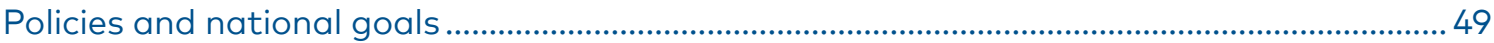

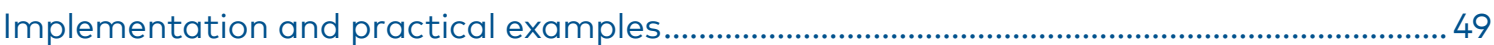

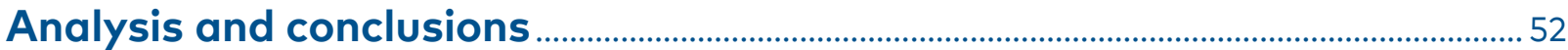

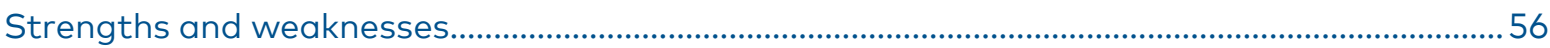

Further efforts and policy recommendations................................................................................. 57

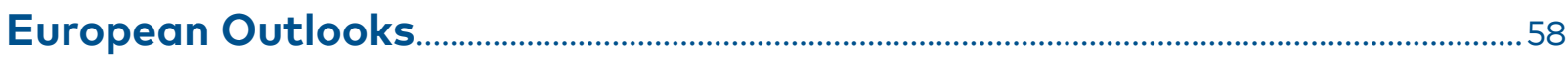

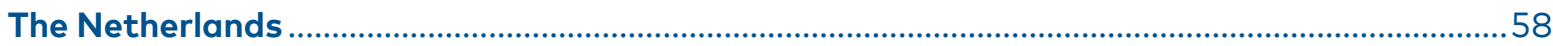

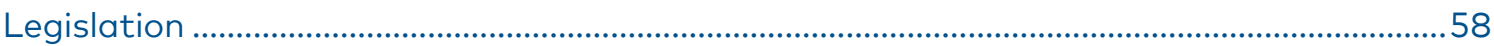

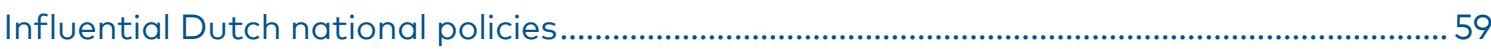

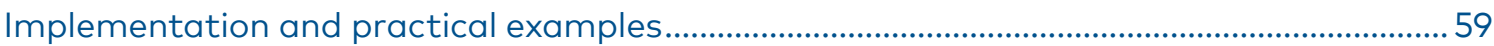

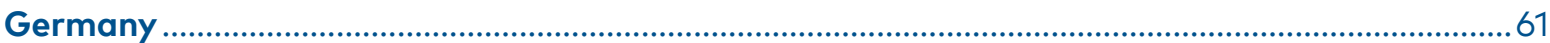

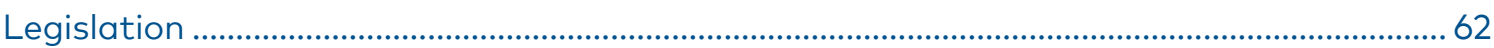

The importance of maintenance for quality urban greenspace ...............................................63

Examples of local and regional strategies, instruments and practices ...................................64

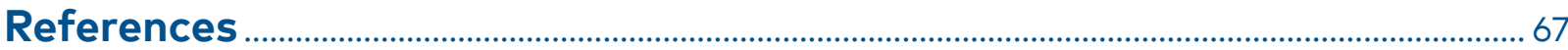

NORDREGIO REPORT 2020:3 


\section{Summary}

In the light of compact city aspirations and commitments in the Nordic Region, it is appropriate that fresh light should also be shed on green valves and their application in urban areas. Spatial planning plays a critical role here, determining the use of land. The legal framework, therefore, needs more attention, particularly when comparing different Nordic planning systems involved in developing, preserving and protecting green values in the urban environment. This study examines and compares the five Nordic countries' planning legislation, and related environmental legislation when it is connected to developing, preserving and protecting green characteristics and qualities in urban areas. It also identifies and briefly describes, the most important national policy/guiding documents and national goals.

What is clear from this study is that all Nordic countries use spatial planning (or at least have the possibility of using spatial planning) to regulate green qualities in urban areas. The available planning instruments differ and have varied implications. The national planning instruments seem to have less actual impact on urban green areas across the Nordic countries compared with the more local planning instruments. Having said that, this does not mean that the national planning instruments are less important, in fact, they can be seen to be steering both discourse and practice in at least one specific direction.

All Nordic countries have similarities in their legislation as regards national and regional goals. All municipal planning frameworks must outline how they have considered such goals in a variety of ways. However, it is often up to each individual planning authority and each planning project to make an assessment of how this will be done in each case. With regard to legal frameworks throughout the Nordic countries, another similarity is that spatial planning, at a general level, needs to consider the natural environment or designated green areas. However, the wording of the legislation may well differ between countries. In certain respects, the language in some legislation could be considered rather vague, as in general it means that each individual planning project should make the assessment as to what is required. It is, therefore, not mandatory to regulate green space through detailed plans, for example.

In all Nordic countries, regulating green values in urban areas is voluntary, with some important qualifications. For instance, local detailed plans in Finland must ensure that there are sufficient parks or comparable areas suitable for local recreation in the zone covered by the plan, or in its vicinity. Though green space is mainly regulated in municipal, and detailed plans across the Nordic countries, Finland's legally binding regional plans are used to pinpoint the general structures of land use, for instance in relation to green infrastructure. At a municipal level, the general structure, or zones of land use, are outlined to varying degrees in all Nordic countries. In most of these countries, urban green areas are in fact regulated as public space, or as unspecified land in "development district" (kvartersmark) or similar. Norway is the country which is most distinguished from other Nordic countries in this regard. There, urban green space is regulated as a particular land-use objective, or as a zone requiring special consideration - in other words, it is acknowledged as being a distinct zone with its own particular legal concept.

Another distinct and successful regulatory framework for urban green space is the National Urban Parks arrangement in Finland, where willingness exists among many cities to establish a national urban park: that is, to preserve green areas as a connected network across the city.

Based on the findings of our study, we conclude with the following requirements for further action:

First, there is a need to gain a better understanding of the implementation of legislation, from a comparative Nordic perspective.

- A study of practical examples in-depth, including interviews and/or workshops with spatial planners, environmental planners, and policy-makers at different levels of government, would be a useful method for further exploring the practical use of this legislation. 
Second, studying local policies in relation to developing, preserving and protecting green values in urban areas could also be useful in identifying new, innovative policy tools and proposals.

- Third, investigating the potential use of the 'green space factor', or similar, being integrated into planning legislation - either as a voluntary or mandatory tool. What could the effects of such an approach be?

- For example, national authorities could continue to take initiatives to discover the most ap- propriate solution, in their specific national contexts, for tools such as these to be integrated into the current legal framework.

- Fourth, creating incentives at national level to encourage municipalities to adopt a certain trajectory when it comes to developing, preserving and protecting green urban areas (for example, through being inspired by the example of National Urban Parks in Finland). 


\section{Sammanfattning}

I ljuset av planeringsidealen om den kompakta och täta staden bör fokus också riktas mot gröna värden i urbana miljöer. Här har samhällsplaneringen en avgörande och viktig roll eftersom den reglerar markanvändningen. Därför behöver mer uppmärksamhet riktas mot det legala ramverket, särskilt för att kunna jämföra de nordiska planeringssystemen när det gäller att utveckla, bevara och skydda gröna värden i urbana miljöer. Denna studie undersöker och jämför de fem nordiska ländernas planlagstiftning och deras relaterade miljölagstiftning med avseende på utveckling, bevarande och skydd av gröna värden i urbana miljöer. Studien identifierar även och beskriver kortfattat viktiga nationella policyer och vägledande dokument samt nationella mål.

Vad som blir tydligt i denna studie är att alla nordiska länder använder sig av samhällsplanering, eller åtminstone har möjligheten att använda sig av samhällsplanering, för att säkerställa gröna kvaliteter i urbana miljöer. De tillgängliga planeringsinstrumenten skiljer sig åt och har olika inverkan. De nationella planeringsinstrumenten verkar ha mindre faktiska effekter på urbana grönområden i alla de nordiska länderna jämfört med de mer lokala planeringsinstrumenten. Med det sagt så betyder det inte att de nationella instrumenten är mindre viktiga, utan faktum är att de styr diskursen och planeringspraktiken $i$ en specifik riktning.

De nordiska länderna har liknande lagstiftning gällande nationella och regionala mål. All kommunal planläggning måste indikera hur dessa mål har beaktats på olika sätt. Dock är det ofta upp till varje individuell planeringsmyndighet att för varje enskilt planeringsobjekt göra en sådan bedömning. Inom de legala ramverken finns det ytterligare likheter mellan de nordiska länderna, såsom att samhällsplaneringen, på en generell nivå, ska beakta natur- och grönområden. Formuleringen $\mathrm{i}$ lagtexterna kan dock skilja sig åt mellan länderna, där språket i lagtexterna i vissa avseenden kan uppfattas som ganska vagt eftersom det generellt sett är upp till varje individuellt planeringsprojekt att göra den bedömningen. Det är således inte obligatoriskt att reglera grönområden i till exempel en detaljplan.
I alla nordiska länder är det alltså frivilligt att reglera gröna värden i urbana miljöer, dock med några viktiga undantag. Till exempel, $i$ en detaljplan i Finland måste det säkerställas att det finns tillräckliga parkområden eller andra områden lämpliga för lokala rekreationsändamål i planområdet eller $\mathrm{i}$ dess omedelbara närhet. Grönområden regleras i de nordiska länderna i huvudsak i kommunplaner/översiktsplaner och detaljplaner, även om de finländska juridiskt bindande landskapsplanerna (regionplaner) också används för att peka ut generella strukturer i markanvändningen däribland grönstrukturen. På kommunal nivå markeras, om än i olika hög grad, generella strukturer i markanvändningen eller zoner för olika slag av markanvändning. I de flesta nordiska länder betecknas urbana grönområden som allmän platsmark (offentlig plats), eller som odefinierat markområde på kvartersmark eller liknande. Norge är det land som skiljer sig mest från övriga nordiska länder. Där regleras (urbana) grönområden som ett eget markanvändningsmål eller zonering som kräver särskild hänsyn - med andra ord är det erkänt som ett eget objekt och legalt koncept.

En annan speciell och framgångsrik reglering av urbana grönområden är nationalstadsparker i Finland där det dessutom existerar en vilja hos många städer att etablera en nationalstadspark och således bevara dess gröna områden.

Utifrån resultatet $\mathrm{i}$ vår studie kan vi dra slutsatsen av behovet för följande vidare insatser:

- För det första, att det finns ett behov att från ett nordiskt perspektiv få en bättre förståelse för praktiken och tillämpningen av planlagstiftningen.

- En studie av fler praktiska exempel som är mer djupgående, vilket inkluderar intervjuer och/ eller workshoppar med samhällsplanerare, miljöplanerare och beslutsfattare på olika förvaltningsnivåer, vilket skulle vara en användbar metod för att ytterligare undersöka tillämpningen av lagstiftningen.

- För det andra, studera lokala policyer i relation till att utveckla, bevara och skydda gröna värden $\mathrm{i}$ urbana miljöer, vilket kan vara en användbar metod för att identifiera nya innovativa policy-verktyg och -rekommendationer. 
- För det tredje, undersöka den potentiella användningen av grönytefaktor eller liknande, i syfte att den ska bli integrerad i planlagstiftningen antingen som ett obligatoriskt eller frivilligt verktyg. Vad skulle effekterna av ett sådant verktyg bli?

- Nationella myndigheter kan fortsätta ta initiativ för att hitta de mest lämpliga lösningarna $i$ deras nationella kontext gällande hur verktyg som dessa bör integreras i det existerande legala ramverket.

- För det fjärde, skapa incitament på nationell nivå som uppmuntrar kommunerna att gå i en specifik riktning när det kommer till att utveckla, bevara och skydda gröna stadsmiljöer (exempelvis genom att låta sig inspireras av nationalstadsparkerna i Finland). 


\section{Planning for green qualities in the compact city}

The current planning practices and discourses in Nordic countries, and in Europe as a whole, revolve to a large extent around an urban norm involving the ideal of developing 'compact cities' (ones characterised by intentional density and short distances for travel). This means that the norm, the compact city, is often perceived as necessary and sustainable in contexts where densification of the built environment is seen as a unique solution to urban challenges (see e.g. Tunström et al, 2018). The opposite, what is known as 'urban sprawl', is often viewed as a deviation from this norm and something to be avoided. There are, of course, both advantages and disadvantages to dense urban structures. When it comes to urban green areas, one risk is that the built environment is rendered dense at the expense of existing green structures in, or in proximity to, urban areas. In the Nordic region, some evidence exists that people in densely populated areas with low or no access to private gardens compensate for this by the increased taking of second homes (Strandell and Hall, 2015). The second home phenomenon is also widespread in the Nordic region (see Slätmo et al, 2019), and could, therefore, easily serve as 'compensation' for a large proportion of the Nordic population. For spatial planning in urban areas, this form of 'compensation' is one of the core challenges for dense or compact city planning. One strategy to avoid the need for second home compensation among urban dwellers is to increase the number of allotment garden cottages and private gardens. This is in order to increase the quality of life in urban areas (Strandell and Hall, 2015; Qviström, Bengtsson and Vicenzotti, 2016). Another strategy would potentially be to increase access to a variety of green structures in urban areas.

In a recent study of the Nordic countries using grid-level statistics, population dynamics were highlighted, showing that even though some municipalities are shrinking, there are often growing cells in the urban settlements (Stjernberg and Penje, 2019). This indicates that densification is also occurring in some shrinking municipalities, or at least there is a movement of people into the urban cores of these areas.

It is in the light of the compact city aspirations and current population dynamics of the Nordic region that our attention must now turn towards 'green values' and green areas within urban areas. Spatial planning plays a critical role here, since it determines the use of land. Nordic countries are quite similar in terms of comparative planning systems in an international context, including their emphasis on strong municipal self-governance and the right to regulate land use through spatial planning. Planning systems in the Nordic countries have often been thought of as comprehensive in character, not least because of their strong welfare state traditions and their focus on bringing together different sectors through the application of a distinct spatial lens; but also on account of their formal, hierarchal and integrated public planning systems (CEC, 1997; Nadin and Stead, 2008; Smas and Lidmo, 2018). Despite this, actual planning systems in the Nordic countries differ when it comes to available planning instruments, but also in terms of whether they are statutory and legally binding, or voluntary.

The legal framework, therefore, needs more attention, especially when comparing Nordic planning systems in relation to developing, preserving and protecting green values in urban areas. This study, therefore, aims to examine and compare the specifics of five Nordic countries' planning legislation and related environmental legislation ${ }^{1}$ in terms of developing, preserving and protecting green qualities in urban areas. The study also aims to identify, and briefly describe, important national policy/guiding documents and national goals. Overall, it aims, therefore, to answer the following questions:

1 And other relevant legislation, if identified. 
1) How do land use and planning legislation in each country consider urban green areas when it comes to developing, preserving and protecting specific green qualities or facilities in urban areas? (Brief description, including quotes/examples from the legislation.)

2) Where relevant, how does the related environmental legislation in each country consider urban green areas when it comes to developing, preserving and protecting green qualities in urban areas? (Brief description, including quotes/examples from the legislation.)

3) Who or which is the responsible actor/ministry at a national level for monitoring the abovementioned sections of the law, in consideration of urban greenery?

4) What are the most relevant and most influential national guidelines/policies towards developing, preserving and protecting green qualities or facilities in urban areas?

\section{Method}

This study was conducted by reviewing each Nordic country's planning and related environmental legislation, as well as looking at important national goals, policies and guidelines. To validate these national reports, at least one national policy-maker from the national ministries or agencies in each Nordic country has reviewed the text concerning the national situation. Moreover, the implementation of legislation and policies has been illustrated through relevant examples from each country. The report also compares two other European outlooks, Dutch and German respectively, in order to include additional perspectives (from both Nordic and international learning) in relation to developing, preserving and protecting green values/practices in urban areas. 


\section{Planning systems in the Nordic Countries}

Planning systems in the Nordic countries have many similarities, not least because municipalities can regulate land use in a variety of ways through municipal and local/detailed plans in each of them. The number of statutory planning instruments varies, as well as the role of national and regional authorities in these processes. The status of planning instruments (in terms of whether they are legally binding or not) is also a crucial difference when it comes to comparing different Nordic planning systems.

The planning system in Denmark has in recent years undergone many changes (see more in the Danish chapter below) and has become increasingly strategic and growth-oriented since 2000. The regional planning authorities were dismantled as a result of regional reforms carried out in 2007. Then, in the new 2017 Planning Act, the chapter on regional development planning was removed altogether (ESPON COMPASS, 2018). The Danish planning system consists, therefore, of national and local planning instruments. National planning reports, overviews of national interests regarding municipal plans, and national planning directives (including specific directives for the capital region of Copenhagen) are important national instruments for guiding planning at the municipal/local level. The national planning reports outline a national vision with regard to functional, physical development. Additionally, an overview of state interests is published every four years by the Danish Ministry for Business. At the local level, there are two main planning instruments: the municipal plan (kommuneplan), and the local development plan (lokalplan), which is legally binding. The municipal plan has been complemented by an obligatory municipal strategy (kommuneplanstrategi), which should be revised during the first part of every mandate period and should include a political strategy - something which is prioritised in the municipal plan.

In Finland, national planning guidance is mainly found in the national land-use guidelines, which are designed to ensure that issues of national im- portance are considered in regional and municipal land-use planning. In accordance with the Land Use and Building Act, the guidelines must be taken into account, and their implementation must be promoted in regional planning, municipal land-use planning and the activities of the state authorities.

At the regional and local levels, there are three key planning instruments: regional land-use plans (maakuntakaava/landskapsplan), local master plans (yleiskaava/generalplan) and local detailed plans (asemakaava/stadsplan). The regional landuse plan is legally binding and guides national and regional land-use goals at the local level. At the regional level, the regional councils (made up of all the municipalities in each region) are responsible for developing regional land-use plans; these guide local-level plans and policies. In accordance with an amendment in the Land Use and Building Act, regional land-use plans do not need to be approved by the Ministry of the Environment since January 2016.

The local master plan is primarily a land-use plan allocating areas for different land-use purposes, such as housing, traffic, services and recreation. The local master plan should comply with the principal land-use guidelines outlined in the regional land-use plan. Local detailed plans, which conform to the local master plan, regulate what can be built and the functions of buildings. It is also possible for two or more municipalities to draft a joint master plan, but this must be approved by a joint municipal organ.

In Iceland, the National Planning Agency, under the aegis of the Ministry of the Environment, is responsible for the main national planning instrument - the national planning strategy, which presents national guidelines for land use at the local level. At the regional and local levels, there are three main planning instruments: regional plans, municipal plans and local plans. In the capital region a regional plan is mandatory, but for all other municipalities it is voluntary and has no corresponding administrative level. Two or more local authorities have the option to join forces voluntarily, to cre- 


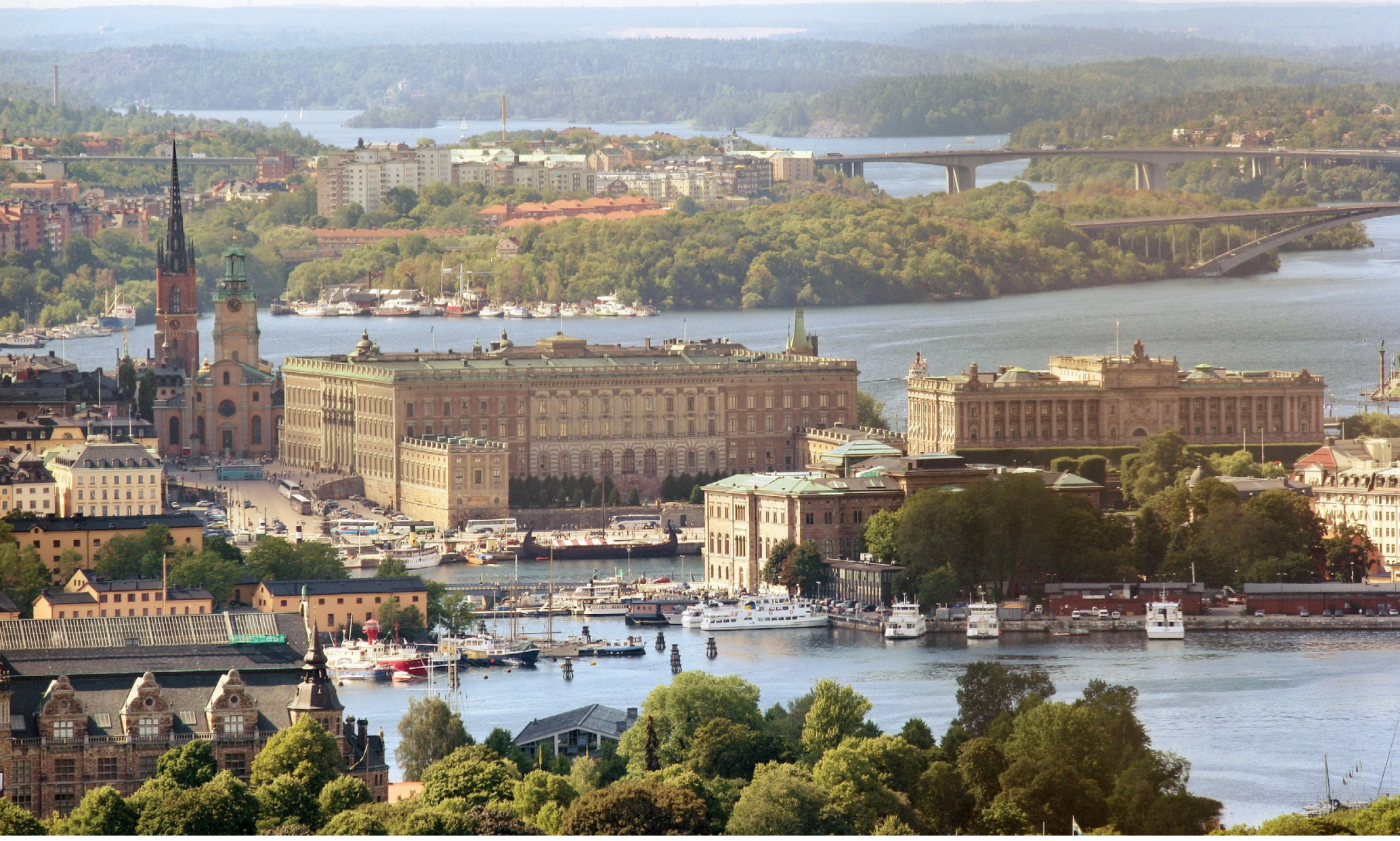

Even though there are no real regional spatial plans in the counties (other than Stockholm and Skåne), the Government requires that there should be a regional development strategy for each county. Photo: Pixabay

ate a common regional plan across municipal boundaries to co-ordinate policies. The key planning instrument in Icelandic spatial planning is the municipal plan, which requires the approval of the municipal council and the Ministry for the Environment. The municipal plan should define policies regarding land use, transportation and service systems, environmental matters and the development of settlements in the municipality. The municipal plan is supported by local plans, which are development plans for specific areas within a municipality. These should be based on the municipal plan and should contain further details about its implementation. The regional plan, the municipal plan and the local plan are all legally binding documents.

In Norway, at the national level, there are four different planning instruments: national expectations regarding regional and municipal planning (nasjonale forventninger til regional og kommunal planlegging), central government planning guidelines (statlige planretningslinjer), central government planning provisions (statlige planbestem- melser) and a Government detailed plan (statlig arealplan). The national expectations are presented every fourth year and include the Government's guidelines on the appropriate focus for counties and municipalities in their local planning (with respect to national policies of importance). Central government planning guidelines also aim to guide regional and local plans and to draw attention to and propose issues of particular national importance. The central government's planning provisions can be used to clarify national expectations for planning and to highlight national policies in key areas of planning. The Government may also draft a national detailed plan, if this becomes necessary, in order to implement a project that is of national interest. The central government's landuse plan can be established either as a detailed zone plan or as part of a municipal plan.

At the regional and local levels, there are five main planning instruments: the regional planning strategy (regional planstrategi), the regional plan (regional plan), the municipal planning strategy (kommunal planstrategi), the municipal plan (kom- 
muneplan) and the detailed plan (reguleringsplan). The regional authorities (fylkeskommuner) are responsible for developing regional plans, which are guided by regional planning strategies but should also be in line with national expectations and guidelines provided by the ministries. The regional plan is not legally binding for municipalities but provides guidance for municipal planning. The regional planning strategy and the municipal planning strategy have to be revised every fourth year. They are synchronised with the election period of the regional and local government. The planning strategy sets priorities for planning activities over the coming four-year period.

The municipal plan includes both a social element (samfunnsdel) and a land-use element (arealdel). The social element features strategic priorities for the development of society as a whole, for public services, and for a spatial development policy. The land-use element has maps and provisions which are legally binding for detailed plans and building permits. There are two forms of detailed plans: area zoning plans and detailed zoning plans. The area zoning plans are mainly used for larger areas and for more extensive urban construction projects, while detailed zoning plans are applicable to smaller areas and limited construction projects.

In Sweden, there are no national planning instruments guiding regional and local planning, and no regional land-use plans, other than in the counties of Stockholm and Skåne. Local planning is steered by the Planning and Building Act and the Environmental Code, which regulate areas of national importance that are protected specifically because of their high environmental value. The areas of national interests could, however, be considered as a planning instrument that to some extent is regulative, because regional and local planning must relate to them (see ESPON COMPASS, 2018). This legislation is enforced by county administrative boards (länsstyrelsen), which are tasked with monitoring the enforcement of national policies at the local and regional levels, thus ensuring that municipality's comprehensive plans (översiktsplan) are kept in line with national regulations. Even though there are no real regional spatial plans in the counties (other than Stockholm and Skåne), the Government requires that there should be a regional development strategy for each county.

The responsibility for spatial planning lies with the municipalities, and there are two key planning instruments applicable at the local level: the municipality's comprehensive plan (översiktsplan) and the detailed plan (detaljplan). The comprehensive plan is not a legally binding plan but should include guidance on future land-use development and should describe long-term strategic developments within the municipality. The comprehensive plan should be co-ordinated with national and regional goals and should take into account national interests, such as national environmental quality goals. In addition, the comprehensive plan guides the legally binding detailed plans that regulate the use of land and water areas. 


\section{Legal framework and national policies}

\section{Denmark}

The Danish spatial planning system is built around general guidelines for planning which are set at the state level, while the municipalities are responsible for applying these guidelines and translating these policies into their municipal plans and into local development plans. This planning system has undergone several changes in recent years. The main reasons for this have been to simplify the process and to decentralise decision-making authority while establishing a clear division of responsibility. These changes have also had the purpose of enabling more creativity and freedom for the municipalities, enabling them to control their own development to a greater degree. While more public participation was one of the intended goals of further decentralising the system, these changes have also provided more room for contractors and development companies to participate directly in urban development.

Allowing local authorities to control their development activities as much as possible and with widespread participation, while still delivering public goods, seems to be what the Danish planning system is trying to achieve. On the other hand, whether the current system is able to deliver all of the above goals remains debatable. Allowing for more freedom and participation among different actors operating within a market system can have a significant impact on delivering public goods, such as green areas and recreational spaces.

This chapter will, therefore, provide a brief overview of the tools available to secure, develop and create green areas in Denmark, within the country's existing planning system, while at the same time stressing public participation and the role of the local authority that keeps the national interest in mind.

\section{Legis/ation}

Danish Planning System - moving decisions closer to the local

The Danish Planning Act provides the main guidance for spatial planning, although other acts, regulations, and policies are relevant as well. The development of spatial planning in Denmark during the twenty-first century has increasingly become more strategic and growth-oriented (Galland, 2012; Olesen and Richardson, 2012). Overall responsibility for spatial planning in Denmark was moved from the Ministry of Environment to the Ministry for Industry, Business and Financial Affairs in 2015. The most recent changes and developments regarding the Planning Act have evolved around further decentralisation of decision-making authority involved in planning, while at the same time promoting strategic planning, reinforcing public participation in planning processes, and improving the opportunities for converting disused industrial sites to other urban uses. Also, there has been an emphasis on promoting development in different districts of the country, protecting urban areas against climate change (and making them resource-effective), preserving attractive and vibrant town centres, and keeping coastal areas open.

One principal and important development within the spatial planning system has been the gradual abolition of regional planning authorities. "In 2014, the Danish Parliament passed an amendment to the Business Promotion Act (Erhvervsfremmeloven), combining the regional development plan and the regional business development strategies in a new regional strategy for growth and development (Vækst- og udviklingsstrategi). The regional strategies had previously been regulated by the Planning Act" (Tepecik Diș et al, 2014: 37). Since then, the current version of the Planning Act has moved further decision-making authority to the local level. The new act delegates responsibility for planning between the five regional councils and the 98 municipal councils ( $\$ 2$, Plan- 


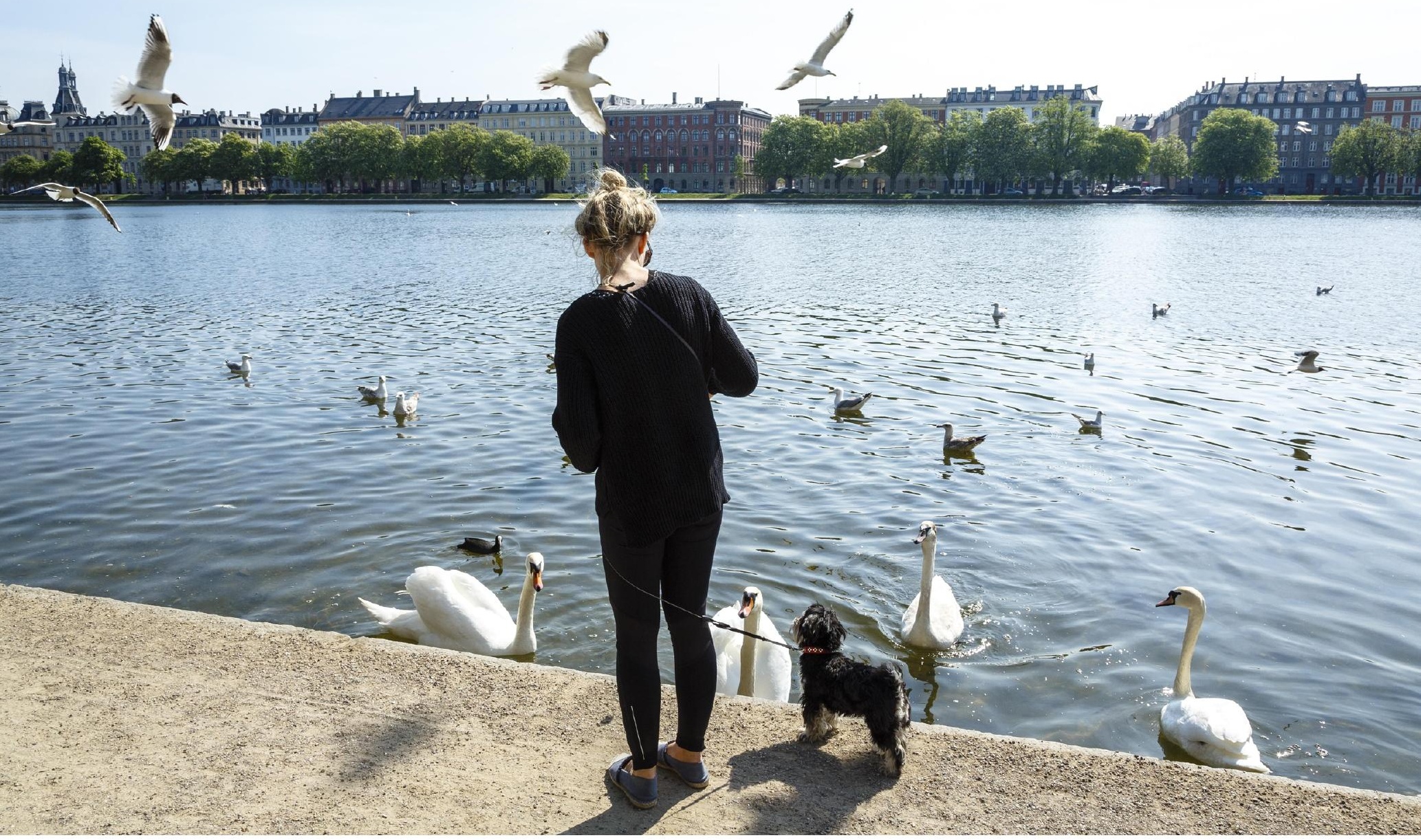

Copenhagen. Photo: Yadid Levy/norden.org

ning Act). Local councils in Denmark are, according to this provision, responsible for planning in both town and country. This means that municipal planning is the main type of planning for development and land use at the local level.

"Land-use planning in the rural areas was moved from the regional to the municipal level. The role of the regional development plans has been transformed from land use to a non-binding strategic and communicative instrument, the role of which is to facilitate dialogue between all regional stakeholders: public and private, local and regional" (Groth and Sehested, 2012: 13). The latest modernisation of the Planning Act, from 2017, was then carried out in order to facilitate "growth and development in all parts of Denmark" (Danish Government, 2015). In short, the new legislation should provide more freedom for the municipalities and more flexible urban planning overall. The role of regional authorities has, therefore, been more or less abolished, while the municipalities have taken over responsibility for planning issues.

This transformation has, therefore, involved less national involvement in local planning, but also new possibilities, for example, in relation to retail developments. At the state level, the government is responsible for ensuring the recognition of national planning interests in a more decentralised planning process, and in other more complex spatial planning cases related to the natural environment. Regional councils then have the role of developing regional spatial development plans, which are general strategic plans for each of the country's five regions.

Moreover, the updated Planning Act has confirmed the division of the country into different zones (rural, coastal, urban) with various conditions and different rules. Municipal plans in Denmark, therefore, assume the role of setting overall targets and guidelines for an individual municipality's development, while the more local development plans remain the foundation of the Danish spatial planning system. They are the place where the political strategy and objectives of the municipal plan are made tangible. All of this is required to build upon the foundation laid down by the National Planning Act and by the Ministry for Industry, Business and Financial Affairs - which is also responsible for protecting national interests through national planning. 


\section{The Planning Act}

The Danish system differs from those in Sweden and Norway, in the sense that the Planning Act is separate from the Building Act. The Planning Act is intended to ensure that overall planning precepts unite the interests of society with respect to land use, and help protect the country's natural environment. The intention is also that the development of society as a whole becomes sustainable in respect to people's living conditions and also to the conservation of wildlife and vegetation ( $\$ 1$, Planning Act). Among provisions listed in the Planning Act are that the creation and conservation of valuable buildings, urban environments and landscapes need to be ensured. A great deal of the Act is additionally devoted to preserving open coastal areas as a continued, important natural and landscape resource. The Act also sets out the importance of the preservation of air, water, and soil quality, and aims to involve the public in the planning process as much as possible. However, the Planning Act also emphasises the importance of creating a good framework for business development and growth.

The Act does not refer specifically to urban green environments in any detail. Rather, as stated earlier, it provides a general national framework that must be considered when more detailed planning proposals are written down at the local level. As set out in the Planning Act, local development plans remain the foundation stones of Denmark's spatial planning system. Local development plans present principal objectives and political strategy while providing a comprehensive overview of the proposed development and presenting specific plans for housing, workplaces, transport, and so on. Local development plans determine how a smaller area can be developed and utilised. In short, local development plans are where policy is put to practice, but within the framework that the Planning Act lays out. A great deal of information must, therefore, be considered, including protection of the natural environment, water preservation, and other obligations specified by the Planning Act. Once a plan has been approved by the local authorities, it also becomes legally binding.

\section{Regional development plans}

Regional development plans also have a part to play in the overall planning system, but they no longer address land use, and they are no longer regulated within the Planning Act. Instead, re- gional development reports have been transformed into a non-binding instrument to facilitate dialogue between all regional stakeholders. They have been turned into a comprehensive evaluation which describes the desired future development of a region's cities and towns, rural districts and peripheral areas, as well as the natural environment. These plans must cohere with other planning provisions, and ensure focus on a business development strategy and an employment strategy. They must further development strategies within the rural development programme, as well as local and regional Agenda 21 strategies, plus other regional strategies and plans - including those concerned with education, training and culture.

\section{Municipal/local authority plans}

The local council is responsible for establishing a policy for the development of both towns and the countryside. The municipal plan links national planning and the provisions of local development plans on the use and development of each local district, as well as forging a connection between national planning and the specific administration of rural zones. The guidelines in the municipal plan concretise the general structural objectives, while the subjects it deals with must be in line with the framework of the Planning Act. These guidelines can, for example, designate the different types of land to be protected. The Planning Act specifies that the planning and policies of a local authority shall then be put forward in local development plans, or so-called detailed plans (Planning Act).

\section{Local development plans/detailed plans}

Local development plans, sometimes called detailed plans (Lokalplan) are, as the name implies, thorough plans that allocate specific areas of land for their intended purposes. This makes local development plans the principal instrument when it comes to planning. But there are many other commitments and responsibilities that come with making local development plans. They must be in accordance with the municipal plan, for example, and they cannot conflict with other specific regulations and directives put forward by the Planning Act, including the European Union (EU) Directive on Natural Habitats (Natura 2000).

The Planning Act says of local development plans that "[a] local development plan may include provisions on the use of the area, including the reservation of specified areas for public purposes". Later 
in the same chapter, there are passages about "the establishment of garden associations for new allotments garden areas" ( $\$ 15$, Planning Act). The Planning Act also makes clear that municipalities are to safeguard areas that have "...cultural-historical conservation values, including the location of valuable cultural environments and other significant cultural-historical conservation values" and has responsibility for "...ensuring landscape conservation values and the location of landscape value areas, including larger, cohesive landscapes ... safeguarding geological conservation values, including the location of areas of special geological value" (§11, Planning Act).

These laws are mainly advisory, but in some instances, they also put clear obligations on municipalities to address certain topics in their plans, in accordance with the Planning Act as well as with other directives the Act addresses, and with other national laws. The Planning Act states that municipal plans must contain guidelines for 27 specific themes which are listed in article \$11a of the Act. It also puts a direct obligation on municipal plans to make proposals on nature preservation issues.

\section{Other environmental protection guidelines and obligations}

"The municipal plan must contain guidelines for safeguarding nature conservation interests, which are made up of natural areas with special nature protection interests, including existing Natura 2000 land and other protected nature areas, co-ecological links, potential natural areas, and potential ecological links" (§11a, Planning Act). This makes planning for nature reserves a requirement for local authorities, and as mentioned earlier, they cannot contradict various other regulations in their plans.

Preparation plans for water resources are also addressed in the Planning Act, and articles within it are devoted specifically to coastal areas. These are meant to protect Denmark's long, open stretches of coastline, which according to the Act should remain free of development which could be located elsewhere (\$4, Planning Act). Local Agenda 21 provisions, part of an international (United Nations) framework for broad efforts to promote sustainable development within different aspects of public administration, are also incorporated into the Planning Act ( $\S \mathrm{Ch}$. 6a). The strategy for Local Agenda 21 includes political objectives which contribute to reducing negative impacts on the environment and promoting sustainable regional and urban development. It must also include targets for promoting biological diversity (§33, Planning Act).

Municipal planning for urban development and the location of technical facilities must additionally take into account valuable areas of the natural environment and its landscapes (\$29, Planning Act). It must ensure preservation of the richness of nature, a good environment and landscape value, so that land use is balanced with regard to nature and the environment. Planning must also take care of the overall natural and environmental considerations which result from EU directives, as well as other international obligations and national legislation. These are in addition to LA21 and Nature 2000, the Habitats Directive (Habitatdirektivet), the Birds Directive (Fuglebeskyttelsesdirektivet), the Water Framework Directive (Vandrammedirektivet), the Nitrates Directive (Nitratdirektivet), the SEVESO III Directive and Risk Order requirements (Risikobekendtgørelsen). Municipal planning for nature, the environment, and the landscape must ensure coherence across the municipal boundaries, - for example in terms of safeguarding drinking water interests, protecting against floods and identifying contiguous landscapes. It must also ensure public access to the natural environment while protecting historical elements and objects or artefacts within the landscape.

In addition, the Planning Act specifies that municipalities must (every four years, during the first half of the municipal election period) prepare a statement setting out their strategy for sustainable development. The Ministry for Business Affairs, succeeding the Ministry for the Environment, must also prepare a report on local Agenda 21 work in regions and municipalities. This should be directed to a committee set up by the Danish Parliament, again every four years. The report should be provided in collaboration with municipal organisations. Most local authorities, therefore, see their local Agenda 21 strategy as existing in close relation to their planning strategies, since both national sector plans and other directives must be complied with in local development plans ( $\S 33$, Planning Act).

Part of the process of updating and improving the Planning Act in recent years has not only been done to simplify and decentralise, but also to meet environmental standards. Many recent alterations were made to include and enhance protection of the environment in the Planning Act and to ad- 
dress the threat of climate change in local planning better. Thus, the Act puts many obligations on local authorities with regard to municipal and local plans, since these are required to consider (and be in line with) a wide range of environmental laws and directives. According to one of the interviews conducted for this study, this has in many ways mainly been a paper exercise for the last four to five years, because the policy focus has mainly been on businesses and on opportunities for municipalities to provide an environment for the growth and development of private actors. However, the needs of the business sector do not always go hand-inhand with policies to provide access to green areas and the environment. In some instances, this has led municipalities to favour economic needs over the environmental (interview).

All the above is relevant to securing, developing and creating green areas in urban environments. In addition, the National Parks Act allows the Minister for the Environment to create national parks. A statutory order stipulates the rules for this, including potentially limiting the planning powers of local authorities in a defined national park area. For this to be possible, a national park plan has to be prepared in order to avoid conflict with the regional development plan, the municipal council, and local development plans.

\section{Building Act}

As mentioned previously, Denmark has a separate Planning Act and Building Act. While the Planning Act puts the aforementioned framework forward as the main instrument for planning and lays the foundation for the whole planning system, the Building Act can also be relevant when trying to secure, develop and create new urban greenery. The Building Act has the principal purpose of securing the quality and safety of buildings, or as it states: "...to ensure that the buildings and the vacant land of the property are of a satisfactory quality, taking into account their intended use, and are properly maintained..." ( $\S 1$. Building Act).

The Act also states that "[a] building may only be put into operation when [it has]: ... wastewater, rainwater, surface water and groundwater discharge that comply with environmental protection legislation; drinking water supply which complies with water supply and environmental protection legislation." The Building Act is also connected to more detailed building regulations. These laws and regulations put forward different requirements that must be met before building permits can be issued by the municipality. Through this instrument, a useful tool exists to ensure that the Act's demands and requirements are met. Depending upon the understanding and definition of the concepts that the Building Act addresses, specific articles could potentially be used to affect the development of green areas.

"The building regulations may lay down rules on the design, layout and use of buildings with regard to: ...calculating building heights and areas and setting quotas for the buildings and terrain" ( $\$ 6$, Building Act). Article 8 then allows for the Minister of Transport and Building to: "lay down rules concerning the minimum distance for buildings, to distinguish between other land or paths" and also to make rules "for the administration of the local council [and] ... for the involvement of neighbouring interests". Exploring the Building Act and the building regulations that are connected to it could, therefore, provide further possibilities for influencing the development of the green portions of urban areas.

\section{Planning at the national level}

So-called national planning directives are also addressed in the Planning Act, and they can be used to identify a specific socially necessary activity which may override local planning provisions. In such cases, these directives are developed by the Danish Business Authority which operates under the aegis of the Minister for Industry, Business and Financial Affairs.

The Plan for the Greater Copenhagen Area, commonly known as the Finger Plan, is a metropolitan area planning process conducted by the Minister of Industry, Business and Financial Affairs through one such national planning directive. In the Planning Act, it is specified that the Minister for Industry, Business and Financial Affairs is required to establish particular rules for planning in the Greater Copenhagen area through a national planning directive, in this case, the Finger Plan. The Planning Act states that: "Municipal planning in Greater Copenhagen shall be carried out on the basis of an assessment of spatial development in Greater Copenhagen as a whole, and shall ensure that the main principles of the overall finger city structure are continued". Later, in the same section, it states further: "...the green wedges are not converted to urban zones" ( $\$ 5$, Planning Act). 
The Copenhagen Finger Plan is, therefore, a national planning directive which is specifically addressed in the Planning Act and has been the foundation of planning for the whole of the Greater Copenhagen region for the past 70 years. The plan, and how it has implemented the directives of the Planning Act and kept designated green wedges undeveloped, is further elucidated by the examples cited at the end of this chapter. Overall, the national planning directives have proved themselves to be an effective and powerful tool which can be further developed at the national level, and which can overrule municipal plans.

\section{Other relevant law, regulations and directives}

While all the aforementioned acts and instruments remain the most influential ones when it comes to planning, there are a few other laws which have importance in regard to greenery, nature and the environment. Denmark's rules on environmental impact assessment are based on an EU directive, and in that way are similar in their functioning to other EU regulations. The laws on environmental impact assessment ensure that development projects which are likely to have significant effects on the environment are assessed before such projects are given permission ( $\$ 1$, Environmental Assessment Act). Under $\$ 20$ of the Environmental Assessment Act, it is also specified that stress shall be put on biological diversity, with particular emphasis on species and habitats protected under Directive 92/43/EEC, wild fauna and flora in Directive 2009/147 of the European Parliament, and the directive on the protection of wild birds ( $\$ 20$, Environmental Assessment Act).

The Act on National Parks may also be relevant here. National parks can, according to the Act, be established by establishing the current and potential importance of the National Park's natural values - including significant habitats and species or landscape and cultural-historical values (\$2, Act on National Parks). It also says that a national park plan "must describe how the quality of nature can be strengthened, including through the expansion of nature areas and by ensuring continuity and free access to nature ... and development of opportunities for outdoor life" ( $\$ 18$, Act on National Parks). It also requires that the National Park Plan must not conflict with Natura 2000 plans, with other proposals for implementation under the Environmental Objectives Act, with programmes arising from the Water Planning Act, with Natura 2000 forest plans covered by the Forest Act, or with municipal and local development plans under the Planning Act (\$19, Act on National Parks).

As this overview shows, many different factors must be taken into consideration under the planning process. Great emphasis is put upon different environmental factors and upon the various directives and laws connected to planning. It is, therefore, worth mentioning that when disputes arise, the Environmental Board of Appeal comes into play as an independent, quasi-judicial body. It is the central board of appeals for all matters related to planning, nature and the environment.

\section{Denmark Green Map}

Since 2017, local nature councils have assisted municipalities with designations as part of the Green Denmark Map, an initiative created through an executive order (with accompanying guidance) establishing local nature councils. The Green Denmark Map (Grønt Danmarkskort) is a coherent nature network aimed at assisting the planning of larger and better-connected natural areas in Denmark. This policy process, led by stakeholders at the Nature Agency, under the aegis of the Ministry of the Environment, is based on the European Bird and Habitat directive, and upon the Mapping and Assessment of Ecosystems and their Services (MAES). The purpose is also to support positive developments in biodiversity and to fulfil the good intentions of Denmark's Nature Plan. Concomitantly, designations must contribute to meeting the UN and EU 2020 biodiversity goals, which are also about preventing the further loss of biodiversity.

For instance, the Green Demark Map includes a Biodiversity Map. This is a further layer of mapping providing detailed knowledge of where Denmark's Red List species - and other endangered animals and plant species - live. It also shows where habitats with the highest quality of natural environmental factors are to be found. This digital collection is published by Denmark's Ministry of Environment and Food (2018). The information it contains is often used in regional and local spatial planning, and it is compliant with national guidance on how these different levels should work together in planning (Miljøstyrelsen, 2017).

In municipal plans, municipalities must designate areas to be included in the Green Denmark Map. The network includes existing and potential natural areas, plus associated ecological connections. In designating areas to be included in the 
Green Denmark Map, municipalities must use the national criteria set out in the relevant section of the Planning Act ( $\$ 11$, Planning Act). It is the Ministry of the Environment (Miljø-og Fødevareministeriet) which is the relevant national authority on the interests involved in nature conservation, and which is correspondingly responsible for the Green Map.

There is a particular emphasis on ensuring that there is a connection between the Natura 2000 sites. However, the Green Denmark Map can also include natural areas which contribute to other purposes - including climate adaptation and climate change prevention, a better aquatic environment, and enhanced outdoor life. These may be low-lying areas, afforestation zones, or outstanding landscapes, for example. When identifying areas for inclusion on the Green Denmark Map, municipalities must ensure coherence across municipal boundaries. In this way, the Green Map does not only represent local interests but also regional, national and international goals and environmental policies.

The digital platform for spatial information, PlansystemDK, is a valuable tool which is also worth mentioning in this regard. It is designed to make initiatives like these simpler to identify and easier to turn into reality. The PlansystemDK platform contains plans pursuant to the Planning Act, and it is widely used in spatial planning across Denmark. In essence, it is a national digital register with open access data from the Danish Business Authority. It ensures the standardisation and public availability of vital plan data (2018). The portal includes, for instance, administrative borders, georeferenced information about geology, data on the risks of flooding, and details about different types of intended and established nature protection areas.

\section{National policies and goals}

Main actors, policies, goals, challenges and opportunities

Public policy in Denmark may be said to consider outdoor life as a welfare issue. Good outdoor and recreational opportunities are seen as a part of the wellbeing of a community. They are considered important to the local population, to business, and to tourists. The policy is, therefore, to increase opportunities for outdoor recreational activities by integrating outdoor life into overall spatial planning. At the same time, nature, the environment and landscapes must all be taken into account, while simultaneously avoiding and preventing pollution.

A quick overview of the Danish spatial planning system reveals that the largest proportion of implementation and policy development is done at a local level, while general rules are made at the national level. The municipalities, therefore, carry the main responsibility for spatial planning, but in doing this, they are obliged to follow national strategies, handbooks and guidance. However, this is not a process carved in stone because there is an ongoing dialogue between different actors regarding spatial planning issues. Also, national and international policies (for example, regarding environmental concerns and public access to recreational spaces) come into play and are incorporated into both laws and municipal plans.

At a state level, the Ministry for Industry, Business and Financial Affairs, and institutions operating under it (like the Danish Business Authority) are mainly responsible for spatial matters. So-called national planning reports are also an obligatory part of the Planning Act as it is carried out at national level. After every general election, a report must be published by the Danish Minister for Industry, Business and Financial Affairs on behalf of the Government ( $\$ 4$, Planning Act). This national report is often discussed and reviewed in Parliament, and it is also sent to the local authorities for review (Smas et al, 2012: 17 and the Planning Act).

The Ministry of Environment also has a role to play in all this, along with the Environmental Agency. While regional authorities do not have as much to say in the planning system as was the case some years ago, more decision-making power has been moved to municipalities, and the active involvement of the public has been promoted significantly in recent years. The Minister for Industry, Business and Financial Affairs is also required to publish a summary of national interests in local planning every four years. This summary is taken to represent a snapshot of the planning situation at the time that it is published.

At the policy level, themes established throughout the planning process are embedded in the concept of sustainability. International directives, like the local Agenda 21, Sustainable Development Goals (SDGs) or EU based environmental regulations, are incorporated both into national law and into municipal plans. These policies are implemented across sectors, so green transition and sustain- 
ability must be considered and included within every policy area: land use and spatial development; water management; agriculture, forestry and fisheries; climate change mitigation/adaptation; environmental protection; energy; cultural heritage, and rural development.

In many ways, the Danes, like other Scandinavian countries, have been leading the way when it comes to sustainable development, and this seems to be a trend that will continue in the coming years. The new government that took over after the elections in the summer of 2019 has put even further emphasis on green transition. The environment was one area on which all four parties forming the parliament majority largely agreed upon. They have, therefore, put it on their agenda to further address the protection of coastal areas and to strengthen coordination of efforts to protect coastal areas, while also emphasising further green transition and, for example, the need for more urban forest as means of protecting drinking water.

The main advantage of, and opportunity within, the spatial planning system in Denmark is the fact that much of the development is commonly carried out at national and municipal levels - while moving more authority to the local level and promoting public participation and access to information so that local acceptance can be gained or these decisions. Securing participation, however, is always a challenge, as is improving practical understanding of spatial planning per se. This crosses over into different policy sectors and projects, such as those concerned with nature, water, climate and recreational projects. These are local matters but must also rest upon national interests and policies.

While the regulation and obligation put upon municipalities in the updated Planning Act is to plan for nature protection, and especially to secure continuous green areas that cross municipal borders, less emphasis has been put on green areas closer to the centres of dense urban areas. The legislation focuses more on the outskirts, on green wedges and on corridors. This is quite often defined by transport needs. However, less stress has been put on public space, parks and the like, which are centrally located.

Also, while the Danish planning system has become more local in practical terms, with more limited national involvement, the freedom for municipalities has increased. This has also left room for other actors to make their voices heard and to have influence - not only the general public but also lobby groups, associations and commercial actors, for example. These actors may have a more market-based approach and priorities which differ from national or municipal interests. So with less national authority, securing national-level interests may become harder. This, in its own way, can make it more difficult to protect and promote more public green spaces and the environment.

\section{Implementation and practical examples Example 1 - Greater Copenhagen - The CPH Finger Plan}

The Greater Copenhagen region comprises one cohesive housing and labour market with common regional open-air and green spaces across local authority borders. Because of this, specific rules apply to the area, as presented in the Planning Act ( $\$ 5$, Planning Act). The Finger Plan contains overall principles for urban development, recreational considerations, and other matters. The Minister for Industry, Business and Financial Affairs has responsibility for preparing a national planning directive on the implementation of these principles for the Copenhagen region, which is produced by the ministry's own institution - the Danish Business Authority.

The plan is based upon the aim of ensuring a clear demarcation between town and country and combining urban development with public transport. The so-called 'fingers' that are created by the railway and road network are the basis for green zones (or 'wedges') between the fingers, which are then left undeveloped. These green wedges between and across the urban fingers must not be added to the urban zones or used for urban recreational facilities (Finger Plan, 2013). Through the Finger Plan, which is a clear example of the utilisation of a national planning directive in accordance with the Planning Act, green wedges are protected and kept undeveloped.

In the rest of Greater Copenhagen, however, urban development is planned locally. The national planning directive provides the principles for implementation and is also there to ensure the overall reservation of land for future transport infrastructure, technical installations, noise impact areas (etcetera) of significance for the development of the area as a whole.

The main aim of the Finger Plan is to promote a contiguous green structure in the dense urban centre and in the greater Copenhagen region, which in 
combination with a network of paths will make it possible to cycle from the inner city to large recreational areas in the wedges through a green strip (Finger Plan, 2013). In the Greater Copenhagen area, local councils can object to proposals from other local councils in the area. The aim of this is to coordinate local, regional and national interests through a process of dialogue and collaboration.

The Finger Plan is, therefore, a special directive aimed at steering the development of Greater Copenhagen, since its governance has been historically complex - given that the region embraces numerous municipalities. The directive regulates land use in all the municipalities in Greater Copenhagen by delimiting areas for urban development, green areas, transport corridors, noise impact areas, technical installations, and so on. Accordingly, the directive and the Planning Act state that Greater Copenhagen should be subdivided into four geographical zones - namely the core urban region, the peripheral urban region, the green wedges and the rest of the urban region (where urban development is only allowed in connection with municipal centres).

While the Finger Plan is executed at a ministerial level, it is, in its way, an example of spatial planning tasks and responsibilities being centralized. The overall purpose has been to secure a well-functioning metropolitan area to enhance international competitiveness, all based on the political purpose of converting Greater Copenhagen into a greener urban region. And in that task, it has proved to be quite successful.

\section{Example 2 - Odense, Aalborg and water interest}

Ensuring clean and plentiful drinking water, plus a clean water supply based on clean groundwater is a high priority in Denmark. In short, municipal planning is there to ensure that the country's drinking water resources are not contaminated. The municipalities must, therefore, free up areas with special drinking water interests, and protected areas of water drilling must be kept free of new features which might increase the risk of groundwater contamination. (See the Environmental Protection Agency's Executive Order No. 1697 of 21/12/2016, and related guidance no. 9320 of 31/3/2017). The focus on ensuring optimum conditions in key water areas is considered important nationally, but also in an EU context (the Water Framework Directive).

Some practical examples show how the aims of water protection can co-exist with green in- frastructures and urban green spaces. This concurrence can also be related to the agreement on climate adaptation in 2013, which obliged all municipalities to carry out risk mapping and to draw up climate adaptation plans. The Planning Act provides an opportunity to incorporate climate adaptation considerations and pollution prevention into local plans. A part of the climate adaptation process is the flood directive adopted by the EU, which Denmark has now implemented (via the directive Statutory Order No. 1618 of 10/12/2015). This requires municipalities covered by the directive to prepare risk management plans to focus on the assessment and management of flood risk, including prevention and preparedness. According to this requirement, municipal plans must not contravene a municipal risk management plan.

All can then be related to two different case examples in Denmark. A so-called 'good yards' area in Aalborg has been developed, using planning instruments and regulations concerning water management, flood risk and climate change, in order to address flood risks while making it a public green space as well. Flood maps were used to calculate where flooding could occur, and how rainwater would flow on the surface of the terrain after heavy rain. The results were then used in developing a former freight area close to the centre of Aalborg and in creating an innovative green neighbourhood. Local drainage of rainwater is planned, using rain gardens, green roofs, and open channels to make a system of pools in which rainwater is collected. The pools function as reservoirs which fill up with water as it rains. Both pools in the urban spaces and permanent lakes in the park areas fill with rainwater, and the park areas then function as storage areas for water.

The load on the public sewer, which is a piped part of a stream and the amount of rainwater reaching the downstream recipient is thereby considerably reduced, while green space is created in the process. This relates to management of the risk of flooding from watercourses and lakes, which is addressed in the Planning Act. In this way, the directive has been used to create a clear public good.

Meanwhile, in Odense, a new residential area of around 500 homes in the suburb of Bellinge has been developed, taking water management into consideration. This project is based on sustainable principles. It involves minimising infrastructure, no surface water running into the sewage system, 
increasing biodiversity, minimising the built area, and retaining the current amount of earth in the area - all with a minimum of level adjustment. The area was planned in this way to keep valuable rainwater from entering the sewage system, but instead to benefit the surrounding environment (as well as contributing to the global Agenda 2030 and the SDGs goals). Such plans are examples of how the environmental, water management and international directives mentioned in the Planning Act, as well as Building Act, can be utilised for urban planning, and to provide public goods, while achieving other benefits as well.

\section{Example 3 - Sydhavn at the Copenhagen waterfront}

Roughly a decade ago the then brownfield urban area of Sydhavn was re-developed, transforming the former industrial harbour area into a modern urban neighbourhood with offices and new housing. This process and outcome can be identified as an example of how the execution of policy and national interests are not always fully met. The local levels of administration were those mainly involved with the project, with regulation from the national level. The vision for the project was to contribute to the development of Copenhagen as an attractive, liveable and growing city, utilising the quaysides and former harbour areas to create an attractive urban environment. However, a development company was created in connection with the project, owned by the municipality and the state. It was "responsible for the development of areas in Copenhagen Harbour and Ørestad, and for the maritime activities in the Port of Copenhagen", with the ambition of creating urban districts of international class - vibrant with life" (2007).

The project was also a part of a larger financial plan involving the Metro system in Copenhagen, which was partly financed through land sale by the development company. In this way, spatial planning involved facilitated coordination between development, finance, and transport policy. This led to necessary interaction between municipal planning authorities, private landowners and property developers. In this particular instance, the municipality was not the landowner, the jointly owned company was. The municipality also depended upon private organisations to develop the land and to provide public goods, which were to be secured through different arrangements under the Planning Law. A comprehensive plan was de- veloped by the major landowners and the municipality, which also formed the basis for later local plans.

The project has turned out to have produced a dense urban area, but some have expressed the view that the area is now lacking in cultural institutions and public recreational spaces. Possibly this can be explained, in part, by the institutional design and market-led approach to the project. The project and its results may also reflect some general issues and challenges in planning regarding public participation, and the use of statutory and non-statutory planning instruments.

In the South Harbour project, the main stakeholders in the process were property developers and landowners. Citizen participation was limited to formal requirements in accordance with planning legislation. This might have had an impact since "local plans in a Danish context can take on the character of a highly strategic and instrumental, non-public planning tool, by limiting the arena of negotiation as including only municipality and developers/landowners" (Hansen, J.R, 2017: 47).

The Sydhavn urban redevelopment project included novel and innovative aspects and ideas, while also testing new forms of collaboration and institutional design. However, this has not resulted in more adaptable planning at the district level, which turned out to be rather pragmatic and exclusionary (Hansen and Engberg, 2017: 110). This example shows that it is difficult to be adaptive in the implementation phase, and also highlights the dilemma of regulation or negotiation. The municipalities have a number of regulative tools at their disposal, especially in the local development plan, and they can decline a project. However, when a municipality is dependent upon funds and new neighbourhoods, while also being dependent on property developers and landowners, the situation can become tricky - particularly in a marketled development project, and especially when the municipality is not the landowner.

This example shows that the Planning Act can be used in different ways and that it does provide opportunities for both regulative measures and adaptability. It also enables the different roles and functions of spatial planning instruments in balancing between ensuring long-term continuity while enabling adaptability, and it illustrates the difficulties of ensuring public goods while being dependent on private developers and landowners. In this case, it can be argued, too much private au- 
thority in planning, combined with a municipality's need for economic gains from the project, led to public goods which are considered important (and are very much defined as priorities in public policy) not being delivered.

\section{Example 4 - Using the Green Denmark Map for green walkways in Vejle's municipal plan} In the Vejle municipal plan, there are some examples of the use of Green Denmark Maps as a new planning tool to give priority to outdoor activities, and therefore to green recreational spaces. The updated Planning Act requires municipalities to develop and contribute to the Green Map database, among other things, in order to define and locate existing green areas, but also to map potential new ones. The focus in urban areas has been on green 'wedges', and by mapping all the green areas and corridors that allow for access and outdoor life in the Green Denmark Map, it is believed that the amount of small local trails to connect the areas will increase.

In the Vejle municipal plan, there are contributions to this, and the view has naturally been expressed that urban development should improve access and opportunities to get out into nature, rather than to cut those opportunities off. The plan, therefore, has a local guideline for outdoor areas and trails which are mapped in the Green Denmark Map. The aim is to develop the surroundings through recreational paths and to ensure that the degradation of plants and the environment on account of motor traffic (or example), does not diminish the value of the routes. "Outdoor life must offer good access conditions, support points and opportunities for organised outdoor recreation, for schools and similar institutions, as well as for the general unorganised outdoor life, with an emphasis on the general outdoor life... areas in Vejle should provide easy and close access to outdoor activities, green areas and high-quality nature" (Vejle, 2017: 338).

The plan also says that it is particularly important to secure the natural silence of these areas against increased noise and unrest. Green areas and trees are seen as a vital part of this issue. The plan then states that all green areas, that is "regional outdoor areas, including vantage points, are shown on maps" (Vejle, 2017: 339). In this way, the Vejle municipal plan fulfils the requirement to contribute to the Green Denmark Map, while at the same time using it as a tool to develop, protect and establish new recreational green paths.

\section{Example 5: Green areas in Roskildes} municipal plan

In Roskilde municipal plan, the directives of the Copenhagen Finger Plan, along with other directives from the Planning Act, are incorporated and used to establish further green areas. Planning guidelines promote the notion that in regional development plans, and within municipal plans, a coherent recreational path can be built - one which allows for long walks through the countryside, and also walks from the cities into the surrounding countryside. All these are to be prioritised. In its plan, Roskilde has allocated the outer green wedges of the Finger Plan, along with Roskilde's Green Ring (also defined in the Finger Plan) as outdoor areas. This land is reserved for general use through the national directive of the Finger Plan. It is not for urban outdoor use, nor for agricultural use, and it is not to be included in the urban zone ( $\$$ 12.1, Roskilde kommune 2016).

"When land is allocated this way, with an open character and public access, it may be used for general outdoor purposes and organised outdoor activities when this is done in accordance with the guidelines under the theme of outdoor recreation", the Roskilde municipal plan adds. It then goes into more detail about creating green paths for bicycles, and for people to walk along the green wedges. The plan states clearly that "[n]o building or construction must be planned, or dispositions preventing the establishment of the specified planned paths" (\$14. Roskilde kommune 2016). It also incorporates laws about equal access and utilises the Nature Conservation Act. It even ties the hands of future decision-makers, further stating: "In connection with the detailed planning of recreational trails, the possibility of establishing disabilityfriendly paths ... should be explored. ... According to the Nature Conservation Act, the closure of thoroughfares and paths, or paths leading to coasts, forests and uncultivated land shall, as a rule, not be permitted. ... paths must, as far as possible, be incorporated into future local plans to ensure the possibility of the paths being realised" (\$14.4-14.7, Roskilde kommune 2016).

All this is in accordance with the directive from the planning laws which specifies that municipalities, across their borders, must ensure that a coherent recreational path can be built: one that allows for long walks through the countryside, and from the cities into the surrounding countryside. 


\section{Finland}

The Finnish Planning system is framed by the Land Use and Building Act (Finlex, 1999:132). But the Environmental Protection Act (Finlex, 2014:527) and Nature Conservation Act (Finlex 1996:1096) are also, to a lesser degree, important for spatial planning (see more on this below). Together with the Finnish Biodiversity Action Plan (2013-2020) and five key national land-use goals, these are the main policies which together create the current Finnish framework for developing, preserving and protecting land and water areas - and in particular, green values in urban areas. As in all other Nordic countries, the municipalities play a key role in regulating and monitoring land and water use, despite legally binding regional plans drafted and approved by the regional councils. On the national level, the key actor is the Ministry of Environment, which is responsible for the legislation mentioned above. The Finnish Environmental Institute provides research and data to support the decisionmaking process.

\section{Legis/ation}

\section{Land Use and Building Act}

The aim of the Finnish Land Use and Building Act is to create a healthy, safe and comfortable living environment; one that functions well socially, and thereby takes into account the needs of different groups. There are eleven main objectives for land use. Five of them also set general aims for developing, preserving and protecting the green qualities desired in urban areas. These are the protection of the beauty of the built environment and of cultural values; biological diversity and other natural values; environmental protection and the prevention of environmental hazards; provident use of natural resources; the functionality of communities, and good quality building (Finlex, 1999:132, §5).

Based on the Act's requirements and the hierarchical Finnish system for land-use planning, consideration of these obligations should also be included in regional and local land-use plans. This means, for instance, special attention in regional plans for the "ecological sustainability of land use; environmentally and economically sustainable arrangement of transport and technical services; protection of landscape, natural values, and cultural heritage; and sufficient availability of areas suitable for recreation" (Finlex, 1999:132, §28). In practice, it means, for instance, the provision of special zones and markings in the regional plan for areas that are important for biodiversity, that support green connectivity, that are identified as recreational or protected areas, or that are identified as areas with special natural, landscape or recreational value.

In the local detailed plans, these objectives are ensured by requiring that "the built and the natural environment must be preserved and their special values must not be destroyed. There must be sufficient parks or other areas suitable for local recreation in the area covered by the plan or in its vicinity" (Finlex, 1999:132, §54; see also examples 3 and 4). In addition, chapter 10 addresses special provisions for shore areas: "Buildings may not be constructed in shore zones in the shore area of the sea, or of a body of water, without a local detailed plan or a legally binding local master plan which contains special provisions concerning use of the local master plan or a part thereof as the basis for granting a building permit" (Finlex, 1999:132, §72).

Of course, legally binding regional and local plans must always be founded on sufficient background studies and reports. This means environmental, socio-economic, social and cultural impact assessments for implementing the plan (Finlex, 1999:132, §9). Land use and building decrees set more specific regulations, common provisions for the interaction process between different actors, and technical details for land use and building. It regulates the content of the regional and local master plans, and it sets guidelines - for instance, for the content of the required impact assessments (Finlex, 1999:895, §1).

Urban green areas and their connectivity are considered more directly in chapter 9, which describes the legislation for Finnish National Urban Parks (NUP) (See example 1). This chapter defines this national policy tool as an instrument to support and develop "the beauty of the cultural or natural landscape, biodiversity (added in 2009), historical characteristics or related values concerning the townscape, social, recreational or other special valves of an area in an urban environment." It also sets the legislative instructions for the establishment of NUPs (Finlex, 1999:132, chapter 9, §68-§̧1).

Finally, chapter 12 sets out regulations on streets and other public areas, like parks in the city. "Public areas must be planned and implemented so that they are suitable for their surroundings, based on the local detailed plan. Implementation of a public area comprises its construction or renovation and maintenance, as required by the land use based 


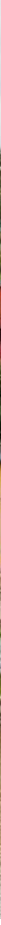

Photo: Pixabay

on the local detailed plan" (Finlex, 1999:132, chapter 12, §90). In addition, the construction of new buildings is regulated in public areas, so that only minor buildings, suitable for the purpose of the area, may be built (Finlex, 1999:895, §46).

Chapter 13 includes special provisions for stormwater management which were added to the Land use and Building Act in August 2014. At that time, amendments were also made to the Water Service Act (Finlex 2001/119). The main purpose of the law section is to establish systematic management for rain and melting waters, especially in urban areas. Management practices should take into consideration the impregnation, detention, conduction, sewerage, and treatment of stormwater. These management practices should also seek to forestall the disadvantages that stormwater can cause to the environment or properties, taking into account the potential increased risk of weather extremes due to climate change. It also supports municipalities in stopping direct stormwater discharges into the sewage system, for example, by integrating new green stormwater solutions into the city landscape. Adapting and implementing these regulations into practice often means a separate municipal storm- and meltwater strategy, or a management plan which can be incorporated into municipal master plans. The Interreg Central Baltic project, iwater, has helped some of the biggest cities in Finland to develop such integrated stormwater management practices (see example 5).

In April 2018, the Ministry of Environment began the process of initiating a comprehensive Land Use and Building Act reform. This work is to be completed on the basis of the effectiveness assessment of the Land Use and Building Act that was carried out in 2014 by the Ministry of Environment. The assessment addresses, for instance, the need for more consistent integration of green infrastructure concepts into the land-use plans (Ministry of Environment, 2014). The reform process will also consider issues related to urban biodiversity (Biodiversity Action Plan Finland, 2019). The ministry is aiming to finalise the process by 2021. The aim of this revision is to simplify the system for land-use planning, with a clear and consistent legal text. It also aims to develop further the effective management of construction and to support the citizens' participation in the planning and decision-making process (Ministry of Environment, 2019). 
Environmental Protection Act and Nature

\section{Conservation Act}

The Land Use and Building Act's relation to other legislation is especially strong in relation to the $\mathrm{Na}$ ture Conservation Act (Finlex, 1996:1096) and its special provisions for the Natura 2000 network, which must be observed when land-use plans are approved and ratified. The aim of the Nature Conservation Act is to "1) maintain biological diversity; 2) conserve beauty and the scenic value of nature; 3) promote the sustainable use of natural resources and the natural environment; 4) promote awareness and general interest in nature; and 5) promote scientific research" (Finlex, 1996:1096, §1). These aims can be applied in both rural and urban areas. The Nature Conservation Act addresses regulations and provisions towards the protection of nature reserves, natural monuments, special biotopes, landscapes and species. All of these can and should be followed similarly in urban areas.

The Environmental Protection Act in Finland applies mainly to $t$ hose industrial and other activities which cause, or may cause, environmental pollution or activities that generate waste. For urban areas, it specifically addresses the regulatory framework for monitoring environmental conditions, particularly regarding air quality, noise pollution and its abatement (Finlex, 2014:527, § 142 and 151).

\section{National policies and goals}

Five key national land-use goals

The national land-use goals are part of the landuse planning system under the Land Use and Building Act. They were set by the Finnish Council of State in 2017. According to the Land Use and Building Act, these goals must be taken into account, and their implementation supported, in both regional and local detailed plans. The goals are 1) Functional communities and sustainable mobility; 2) an efficient transport system; 3) healthy and safe living environment; 4) vital natural and cultural environment and sustainable use of natural resources, and 5) renewable energy supply.

The goal for a 'healthy and safe environment' involves establishing targeted actions, especially for urban contexts. These include sufficient preparations for the increased risk of extreme weather, such as floods or the other effects of climate change. They also involve the mitigation of environmental and health damage caused by noise, tremor, and poor air quality. The goal of 'a vital natural and cultural environment and sustainable use of natural resources' includes preservation of ecological core areas. It also involves green links to enhance biodiversity, the conservation of sufficient recreational areas, and an ecological network with solid natural areas. This particular goal is considered in municipal land-use plans, where 'green connectivity' is often one of the designated topics, and the mapping of green connectivity is frequently done as part of background studies for actual land-use plans. In addition, many regions and larger cities have made separate green and ecological network plans. (See examples 2, 3 and 4).

\section{Finnish Biodiversity Action Plan 2013-2020}

The Action Plan aims to "slow down the loss of biodiversity in urban and built-up areas by increasing knowledge of the subject and developing the related land-use planning, so as to take into account the conservation of biodiversity." The concrete actions it entails are:

A) Encourage municipalities to evaluate unbuilt areas - significant in terms of biodiversity in urban and built-up environments - and the threats they face, and to develop methods of measuring changes in them.

B) Promote the protection and restoration of areas important to conserving biodiversity and the corridors between them in urban environments, and in connection with the surrounding populated and viable rural areas.

C) Develop the principles and methods of planning and managing urban and built-up environments, from the perspective of biodiversity conservation. D) Promote catchment basin-specific stormwater programmes in urban and built-up areas in order to reduce stormwater volumes and enable their natural management (e.g. stormwater wetlands) and to promote biodiversity. Ensure continuity of research related to stormwater (Biodiversity Action Plan Finland, 2019).

The Ministry of Environment has set up a working group to coordinate and monitor the implementation of these actions. In addition to representatives from the ministries, the working group consists of members from national agencies, relevant research institutes, NGOs and other relevant stakeholders. 


\section{Implementation and practical examples}

Example 1 - National Urban Parks in Finland

The Finnish Ministry of Environment coordinates the establishment process of National Urban Parks (NUP). These follow a four-step criterion for evaluating potential NUPs. First, the park must contain natural areas containing valuable biodiversity, cultural elements relevant to the history of the city, and parks and green areas of architectural or aesthetic significance. Second, the park should cover an area large enough to walk from one part of town to another through the park area. Third, it should function as an ecological corridor, allowing species to access and interact with green and blue nature areas outside the city. Finally, the park should be located in the city centre or the immediate surrounding area.

The Finnish approach to National Urban Parks provides an example of how conservation work for urban green areas, and their connectivity, can be integrated into spatial planning policy in a consistent way. NUPs are being established to preserve the beauty of a culturally significant and natural landscape and to maintain ecological corridors and biodiversity, alongside cultural and natural heritage in urban areas. The parks must be solid natural spaces with connections to neighbouring agricultural and forest land where appropriate.

An initiative to establish a new NUP always starts from the local level, moving on to cooperation with the key decision-maker, the Ministry of Environment. The decision-making process follows the usual steps involved in municipal political democracy. The municipality approves the application, and it is prepared in consultation and cooperation with both the city council and local government. A local municipal council submits the application and proposes an NUP management action plan to the Ministry of Environment for the next stage in the decision-making process. In addition to a city's willingness to preserve its green areas and connected networks, another motivation for establishing an NUP is to strengthen its attractiveness as a green, viable city.

Currently, there are nine National Urban Parks established in Finland (Hämeenlinna, Heinola, Hanko, Kuopio, Pori, Forssa, Kotka, Turku, and Porvoo). The first NUP in the country was established in Hämeenlinna, at the beginning of 2001. The area includes the Aulanko nature reserve, the Vanajavesi waterway, and its coastal recreational areas. It is a landscape described and celebrated by poets such as Runeberg and Topelius, and by the composer Sibelius, who had a forest of 97 hectares named after him in the latest expansion of the park. Further, the city restored an industrial site that had previously been a barrier between the urban areas and the cultural landscape and established a green route on former train tracks that connect the city centre with the Aulanko nature reserve. The area covers six kilometres from north to south, five kilometres from east to west, and has approximately 200,000 annual visitors. Many further initiatives to foster ecological links within the NUP were completed after the establishment process. In 2019, 18 years after the NUP was established, the city is preparing for an updated vision and management plan.

\section{Example 2 - Regional assessment of the ecological network in Kanta-Häme}

As mentioned above, the Finnish Land Use and Building Act obliges regions to consider ecological networks that foster biodiversity and other values of nature (Land Use and Building Act, 5 §). This obligation, as well as a region's own interest in understanding what the most crucial ecological links are on a regional level, motivated Kanta-Häme to make an assessment of how things are working for the ecological network (Regional Council of Häme, 2016).

This report was published in 2016 as part of the regional master plan process. It is an important overall assessment, analysing regional green infrastructure jointly with its eleven municipalities and with the involvement of the Finnish Association for Nature Conservation. It identified the core areas for ecological networks and emphasised the most critical green corridors for sustaining regional ecological connectivity. After the ecological network assessment, these corridors were included in the regional master plan, which obliges municipal master plans to include these areas into the final, local detailed plans (Regional Council of Häme, 2016).

The outcomes of this analysis emphasised the importance of regional biodiversity and water management. The report described nature, special biotopes, landscapes and rare species in the region. Core natural areas and ecological corridors were identified, with spatial analysis of land cover in the region and completed through the use of local knowledge. As part of the analysis, the Regional Council assembled planners from the municipalities and representatives from the Finnish Associa- 
tion for Nature Conservation, bringing them to a workshop to comment on the preliminary results of the regional spatial analysis. This part of the report helped regional planners to identify the most crucial bottlenecks. Some ecological links were often found to be visible only on the lower scale of spatial analysis.

\section{Example 3 - Green network and biodiversity plan in Oulu}

A green network and biodiversity plan for Oulu was formed in 2014. It is an example of the kind of separate green and ecological network plan that can be formed in larger cities. Moreover, it is also an example of a background study to the urban master plan, which maps the green connectivity. The study identifies the most important landscapes, natural values and ecological networks which need to be considered in both urban master plans and local detailed plans. The plan considers urban green areas and green networks as 'ecosystem services' that provide a wide range of socio-economic benefits. The ecosystem service approach is intended to facilitate planners' recognition of land-use conflicts and other barriers to implementing sustainable land-use solutions. During the planning process, the concept of ecosystem services was introduced to urban planners, enabling them to develop the ability to integrate this approach into their planning practices (Oulu, 2014).

The process of identifying the core areas and ecological networks in Oulu was carried out alongside spatial analysis and completed through local knowledge. The analysis has been integrated into the urban master plan, and it is also expected to guide detailed master plans as well as the general management of green and recreational areas (Oulu, 2014).

\section{Example 4 - Ecological green network in Jyvåskylä}

In 2012 Jyväskylä made an assessment of its ecological networks as a background study for the local master plan. The decision to conduct this study was motivated by section 9 in the Land Use and Building Act, as well as the national land-use goals. The study identifies core areas for the natural environment and looks at their connectivity. These areas are important for recreational purposes, but they also form crucial forest environments for many species in the area. Basically, the study identifies three types of partly parallel core areas and the links between them. These are core areas for biodiversity, core areas for recreational use and core areas for the forest. In addition, the lack of sufficient ecological links is identified and examined. The core areas, their links, and planned improvements are then considered in the existing land-use plan, involving various land-use zones and special markings. (Jyväskylä, 2012)

Jyväskylä also has a pilot city district for the so-called Green Area Factor in Finland (similar to the city of Malmö in Sweden). One part of the city, Äijälänranta, has a specific regulation in its local detailed plan for constructing and managing outdoor areas. This is a new residential area intended for approximately 800-1000 people, located in the vicinity of Jyväskylä centre. Its green areas are planned using specific green targets. These support the local ecosystem and strengthen stormwater management in the area (Ministry of the Environment, 2015).

\section{Example 5 - Stormwater management plan in Helsinki}

Helsinki formed a strategy for stormwater management in 2008. Implementation of this strategy has been monitored by a cross-administrative working group, which reported the achievements of its measures and its goals to the City Council in 2015. Background work for an updated stormwater management plan was carried out in 2018. It focusses on action towards systematic, sustainable and long-term management practices and priorities in Helsinki. The aim in implementing an updated management plan is to take into account a fast-developing and increasingly compacted city structure, the city's climate change adaptation guidelines, and the need to improve both the urban environment and the quality of stormwater. This can be done, for instance, by connecting stormwater management practices with the maintenance of vegetation, biofiltration and the rain gardens (Helsinki, 2018).

The Iwater project has provided a toolkit that gathers information on good practices for stormwater treatment at different planning levels. So, for example, the toolkit presents a variety of sustainable stormwater management systems and designs that will be tested in newly built-up areas in Helsinki (Interreg EU, 2018). 


\section{Iceland}

When looking at what governs the development, preservation or protection of urban green areas in Iceland, a closer examination is needed of the planning system as a whole. Urban green areas are not mentioned directly in laws and regulations. Rather, urban green spaces fall under different parts of the national laws. These are mainly Acts regarding planning and the environment, but in some instances other laws may apply as well. From a policy perspective, the individual policies and plans of municipalities carry most weight, while recognising that those plans must also consider directives derived from different laws and national policies. An ongoing theme for policies at both national and local levels in Iceland has revolved more and more around promoting sustainable development, equal access, and opportunities, health and recreation possibilities in recent times - while also seeking to create growth. Within local policies, much general emphasis is put on the importance of preserving and developing new green recreational spaces, both because they contribute to environmental goals and also because they promote health. However, policy and practice do not always go hand in hand. It is, therefore, necessary to take a closer look at the tools available to the authorities in Iceland, in their determination to ensure that green areas are protected, and new ones created in urban environments.

\section{Legis/ation}

Iceland's Spatial Planning System

The spatial planning system entails compulsory planning regulation at two governmental levels; national and municipal. It also involves an optional regional level, whereby two or more municipalities conduct a plan collectively. The planning system includes four main instruments: The National Planning Strategy, regional plans, municipal plans, and detailed development plans. In this way, the system is mainly governed at municipal level. The national level is principally responsible for general guidelines regarding land use, and for approving municipal and regional plans. The National Planning Agency (NPA) additionally coordinates national sectoral plans.

At the local level, municipalities are responsible for developing a municipal plan that should include a land-use strategy. They are also expected to take the current national planning strategy into account in the preparation of those plans. Icelandic municipalities also have the option to voluntarily develop what will then become a legally binding regional plan across municipal boundaries. But it should be borne in mind that in Iceland there are only two levels of governance, the state level and the municipal. So this cannot be mandatory.

At national level, the Icelandic National Planning Agency (Skipulagsstofnun) is the state authority, under the aegis of the Ministry for the Environment and Natural Resources. The Agency is responsible for the administration and implementation of the Planning Act, the Environmental Impact Assessment Act (EIA) and the Strategic Environmental Assessment Act (SEA). It is also responsible for assisting and advising local authorities in preparing and reviewing spatial plans, including the approval of municipal plans drafted by local authorities. In addition, the Agency has responsibility for the National Planning Strategy, which mainly includes national guidelines on land use, rather than being a physical plan itself. Various other government agencies are required to offer comments on specific aspects of planning. For example, the Environment Agency provides reviews on nature conservation and pollution, and also on archaeology and housing protection.

Municipal spatial planning is mainly governed by the municipal plan, which is a development plan for specific areas, covering all the land within the boundaries of a local authority. The municipal plan requires the approval of the local authority, and it is then adopted by the National Planning Agency. The so-called local plans are development plans for specific areas within a municipality. These should be based on the municipal plan and should contain further details about its implementation. It is within these plans that policies are put in to practice, and, therefore, they are the backbone of the planning system in Iceland.

As mentioned earlier, two or more local authorities have the option to join forces voluntarily to create a common regional plan across municipal boundaries. Such plans require the approval of the respective local authorities, as well the $\mathrm{Na}$ tional Planning Agency. They will normally form a single geographical, economic and social entity which covers all the land area of the municipalities involved (SEA on Iceland, 2014). This has become more common in recent years. However, the municipalities that together form the Reykjavik Capital Region are since 2010 obligated collectively to make a regional plan, and in recent years they 


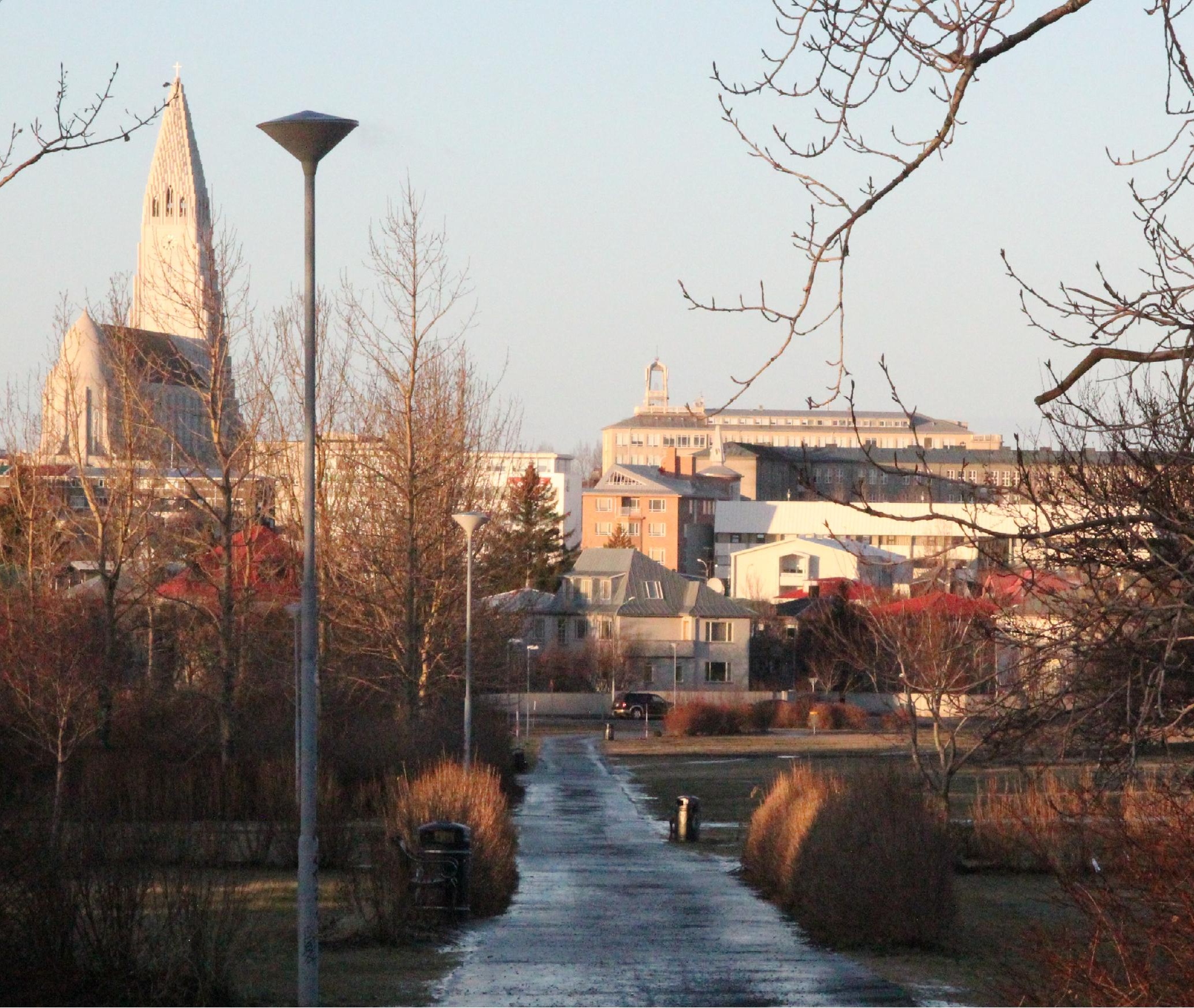

Reykjavik. Photo: Ágúst Bogason

have developed such a plan around the common interests that they have identified. As of 2019, the capital area is the only region in Iceland that has an obligation to make a regional plan. Otherwise, it remains voluntary, as set out above.

Regional plans are legally binding after being approved and adopted by the local and national authorities. The same goes for municipal plans and local/detailed plans, so all planning levels are legally binding at this point. However, the planning laws also state that "the existing plans must be internally consistent. Regional plans overrule municipal plans, and a municipal plan overrules a detailed plan. When making new plans or changes to existing plans, local authorities must take into account the existing national planning policy" ( $\$ 12$, Planning Act).

Allocating land and declaring it a 'green space' within plans developed by the municipalities, (whether collectively in the form of a regional plan or individually) is, therefore, the principal tool for the Icelandic authorities in developing, preserving and protecting what we have been calling 'green qualities' - as well as making the decision legally binding. In many municipal plans 'green space' is used as a wide concept that can apply equally to city and neighbourhood parks, islands within urban limits, coastal areas, organised outdoor areas, recreational and sports-related areas, cycling and 
hiking trails, riding paths, protected areas and water conservation areas. Within more local detailed plans, however, land is allocated more specifically. In urban environments, greenery is most commonly specified as 'public space'.

\section{National policies and goals}

Main frameworks and policies at national level

The National Planning strategy is a relatively new tool for managing all planning in Iceland. Although already presented, and in the phase of implementation, its content, format and processes are still in development. The National Planning Strategy was created on the basis of the Planning Act. It proposes a policy on planning which is intended to ensure common interests in local authority plans. It also aims to support sustainable development and efficient planning. It is also there to support the coordination of policy-making on land use at both state and local authority levels. The strategy is based on the objectives presented in the Planning Act and in official plans. This includes government policy-making on sustainability, as well as analysis regarding all planning and planning developments in Iceland. Where applicable, the National Planning Strategy also takes into consideration local authorities' regional and municipal plans.

"Urban planning contributes to sustainable development of urban areas with dense, continuous urbanization, restructuring of underutilized areas and the promotion of the local community. The development of residential and commercial housing will be in accordance with the needs of the community at any given time and in the future" (National Planning Agency, 2016: 57). Later the National Planning Strategy adds that "it should also promote a healthy environment that provides good living conditions and opportunities for diverse outdoor activities (National Planning Agency, 2016: 59) and also: "...linking to residential areas for the benefit of sustainability in everyday life and increased quality of life" (National Planning Agency, 2016: 57).

As such, the National Planning Strategy is a policy document which is to be implemented primarily through local authority plans (regional plans, municipal plans and detailed plans). It can, however, also influence government programmes on specific issues concerning land use. Additionally, it can entail other planned projects, such as guidelines or development projects to implement certain policy objectives ( $\$ 10$ and $\$ 11$, Planning Act).

As mentioned before, the National Planning
Strategy is a relatively new instrument in planning matters in Iceland. It is now being developed further, taking into account three new policy sectors: climate, landscape and public health. These policy areas will be integrated fully into the existing $\mathrm{Na}$ tional Planning Strategy, for example by providing a more detailed policy framework on landscape considerations in urban and rural planning, in the highlands and in coastal areas - therefore extending and deepening the existing strategy.

As of now, Iceland's National Planning Strategy does not specifically cover a strategy or form a national policy in relation to urban green spaces. Rather, it serves as a general framework of requirements in different fields. The chapter about urban planning does not mention urban greenery in any detail, but as with the rest of the document, it leaves it to the municipalities to develop their own plans. These municipal plans must then take note of the National Planning Strategy as well as other relevant laws and national policies, as noted above. It does, however, present the national goals of promoting sustainable development, supporting the nation's health, securing access to recreational areas and addressing the need for the further development of green infrastructure. In this way, environment and outdoor recreational opportunities are emphasised as important qualities. However, there are no obligations to provide such public goods in urban areas within the existing planning regulations.

Besides the Planning Act and the National Planning Strategy, some other policies and directives must be considered when it comes to spatial planning. Depending on their application in each case, these policies and directives can be quite diverse in their impact. In most instances, for example, the state's Climate Action Plan must be considered (Aðgerðaáætlun í lofslagsmálum, 2018). Urban development and urban planning are also meant to contribute to sustainability, with a focus on quality in the built environment and upon a targeted and integrated urban and transport structure (National Planning Agency, 2016).

Laws on nature reserves can also be used to allocate land for preservation if it is considered to meet certain requirements. "At the initiative of the municipality or municipalities concerned, and after approved recommendations of the Environment Agency, it is permissible to preserve land for outdoor recreation and public use as a public park. The protection of the area shall be aimed at facilitating 
public access to nature and related cultural objects in close proximity to urban areas for outdoor recreation, nature conservation and education." In such instances, the Environmental Agency is responsible for the preparation of such provision, in cooperation with the municipality or municipalities concerned ( $\$ 52$. Nature Preservation Act).

Environmental Impact Assessment and Strategic Environmental Assessment are two forms of scrutiny that play a key part in spatial planning matters in Iceland. According to existing law, environmental assessments should be carried out by teams possessing a range of skills. Iceland's formal guidance on this discusses the relationship between municipal planning and sustainable development. It explains that environmental assessments are meant to have a broad remit in relation to examining environmental concerns. It also stresses the importance of consciously providing a baseline for data that takes into account the full scope and emphasis of the impact assessment, as well as future monitoring of impacts. However, it does not discuss these indicators in depth. The objective of the act is stated as: "...to promote sustainable development and reduce the negative environmental impact, while also contributing to environmental considerations when planning. This should be done with the environmental assessment of certain governmental planning and implementation plans which are likely to have a significant impact on the environment" (Act on strategic environmental assessments, no. 105/2006).

In some instances, planning for a specific area can also fall under the directive on areas that have special cultural or historical values. As stated, these "...must consider that the overall frame is built with respect to the historical and cultural heritage when built, and with, older settlements. Also, to ensure that the visual appearance of the surrounding environment has minimal effect on nature and landscape..." (Mennta- og menningarmálaráðuneyti, 2014). Laws that consider the equality of the disabled can also affect planning, since those laws state that "housing that the public should have access to should be accessible to all, and the same applies to open areas for the public, such as recreational areas and parks" (Action Plan the Disabled, 2017).

Although the aforementioned directives have most relevance for planning in relation to urban green spaces, other laws and regulations may apply in some instances, as the previous examples show. Other laws that may be relevant in some cases include the Act on marine spatial planning and coastal areas. Special clauses may also apply if a zone has been declared as a protection area, for example, because of water protection or natural hazards. In addition, laws on protected areas in urban areas state that: "If it is considered necessary to protect the characteristics of older settlements or other cultural-historical monuments, natural remnants, natural heritage or vegetation for historical, natural or cultural value in the preparation of a zoning plan, without any protection under other laws, the relevant zoning regulations shall be included" (Act on protected areas in urban areas).

\section{Main policies at the local level}

As stated earlier, municipalities must act within the framework of national guidelines presented in the Planning Act and take note of the National Planning Strategy, but how they develop, conduct and implement their local plans is up to them - although the plans must be approved by state authorities. An example of a regional plan, or 'cross municipal border plan' in spatial matter in urban areas is the Capital Area Plan 2040 (Höfuðborgarsvæðið 2040). This was developed and then approved by the seven municipalities in the capital region back in 2015. It is mainly built upon the common interests of the municipalities in question and is concerned with developing an efficient and modern public transport system. It also covers other areas, for example, common beneficial growth in the capital area, international competitiveness, and also creating a healthy common environment in nearby surroundings. So, the municipalities in the Reykjavík region, while securing the growth of the area as a whole, still emphasise that access to public goods (such as recreational areas for outdoor activities and access to the natural environment) must also be guaranteed. The defined 'green spaces' in this plan are, in accordance with the Planning Act, legally binding.

The individual municipal plans also address the importance of preserving and creating green environments and contributing to a more sustainable development. Therefore, the Reykjavík municipal plan that states that "a part of the land owned by Reykjavik will be taken under a special action of 'restoration of wetlands' in accordance to the national policy on climate action" (Reykjavík municipal plan, 2013). The Reykjavik municipal master plan also states that "[a] plan for recreational areas is 
a policy on a continuous web of open green areas that are woven into the city landscape, around the city land, connecting districts, homes, service and commercial areas. A good connection from residential areas to a variety of recreational areas should be ensured, as well as the maintenance of the natural biodiversity of Reykjavik's land and fauna. 92\% of Reykjavik's residents live within 300 metres of a recreational area larger than 2,000 square metres. This ratio should be maintained in concomitance with the densification of urban areas. The quality of nature and landscape within the city and near to residents' homes should not be diminished." (Reykjavík, 2014: 27). Later, the same document defines urban quality as "...the neighbourhoods of the city creat[ing] a setting for lively and attractive places that encourage communication between people and the environment" (Reykjavík, 2014: 30). It is, therefore, clear that existing policies consider access to green spaces important, and in local plans, land for green public spaces is allocated and defined as such. In so doing, this provision also becomes legally binding, according to the Icelandic Planning Act.

\section{Summing up - main actors, laws and policies} While the conduct and implementation of planning matters in Iceland mostly take place at the local municipal level, the guidelines, rules and policies are developed and then approved at national level. The Ministry for Environment and Natural Resources, and the Environment Agency that operates under it, plays a large part in this. The agency's role is to promote environmental protection, as well as to secure the sustainable use of Iceland's natural resources, and to contribute to public welfare by helping to ensure a healthy environment.

In addition to the new National Planning Strategy, which is also created at the national level, it can be argued that the system overall is quite centralised. Nonetheless, and although municipal plans must take note of national policies and interests, these policies are further developed and then carried out at a local level. The state authority then approves plans made by municipalities in order for them to become legally binding - which in its own way also gives some authority back to the national level. In practice, however, this is mainly to ensure that plans are up to standard and that they follow the appropriate regulations. It is an important support mechanism, especially for smaller municipalities, which may in some instances lack the resources needed for regularly implementing detailed plans. In that sense, the NPA provides valuable assistance and guidance in making municipal plans.

In practice, the Icelandic planning system, therefore, comprises a constant dialogue between two governance levels. In terms of policy, we can see that sustainable development, equal access and opportunities, the promotion of health and possibilities for recreation are all highlighted at both local and national level. This has contributed to the two administrative levels speaking with a pretty unified voice on such matters, at least when it comes to planning for green recreational spaces in an urban environment.

\section{Implementation and practical examples Example 1 - Capital Area Regional Plan and The Green Scarf}

A Regional Plan is only a requirement for the municipalities in the Capital Region of Iceland, according to Iceland's Planning Act. For other municipalities, such plans are voluntarily entered into if two or more municipalities want to work collectively towards some common interests. The Plan for the Capital Region is one that, in its making, becomes legally binding. Individual municipal or local plans cannot be in competition with this regional plan. The seven municipalities in the Capital Area have developed such a plan, and one portion of it focuses on safeguarding nature, preserving the landscape and securing recreational areas across the city, all in order to create a better quality of life and improved public health for residents.

This approach has been taken to ensure the creation of permanent, diverse, attractive and accessible open green areas. It will also increase the green appearance of the city through the provision of trees and other vegetation. In addition, it can create and strengthen a continuous web of open green areas that connect districts, homes and places of work across the entire urban area. Such an approach relates to climate goals, too, by encouraging urban agriculture, emphasising home food production, and enhancing the sale of local products to residents. For example, it encourages the home production of eggs and honey by permitting fowl and beekeeping in the city.

The so-called Green Scarf is another vital part of this plan. It involves protecting and further reinforcing the cultivation of trees within the urban area, as well as strengthening city forestation in those peripheral regions that surround the city. 
This will increase the availability of shelter and help improve local weather conditions, it is argued.

Strengthening the "blue threads" that run throughout the city and along the coastline is also a binding commitment that forms part of the regional plan for the Capital Area. This states that "recreational areas should form a continuous web, or a green net, over the city land; one which connects districts, homes, services and commercial areas, ensuring the connection of residential areas to nature in all its diversity, and to recreational areas, linking the Green Scarf and the coastline of the city". Another part of this is, as this suggests, the commitment of municipalities to create a linked web of recreational areas, with a network of pedestrian and cycle pathways that connect homes to workplaces while ensuring a safe pathway for all residents, enabling them to have access to a range of recreational spaces located within a specific distance of home.

\section{Example 2 - Reykjavik's Master Plan and the restoration of the wetlands}

Reykjavík's municipal plan says that "a part of the land owned by Reykjavik should be taken under a special provision for promoting the 'restoration of wetlands', in accordance with the national policy on climate action" (Reykjavík municipal plan, 2013). An area of wetland the size of 100 football fields will be reclaimed in the Úlfarsdalur valley over the next few years. This will be achieved by filling in ditches that were originally dug to drain the land. By this means the area will be turned into a carbon sink, while also creating a public recreational space. This plan also fulfils environmental goals intended to tackle climate change and reduce $\mathrm{CO} 2$ in the atmosphere, creating a greener environment. The restoration of Wetlands is seen as a way of contributing to this goal by creating new green areas, while the development as such rests on international environmental commitments.

\section{Example 3 - The sustainable neighbourhood of Urriðaholt in Garðabær}

The Urriðaholt urban master plan in Garðabær covers an environmentally sensitive area with a pristine lake.

Community participation was a key element in the preparation of a detailed plan for the area, and special attention was given to the relationship between the area's urban character, as well as the natural environment. The aim has been to create a compact and diverse mixed-use, walkable neighbourhood, with local amenities and the opportunity to run good public transport. When integrated with sustainable urban design strategies, this will enhance the wellbeing of those living and working in Urriðaholt in the future.

The site is surrounded by an unspoiled landscape which serves as a bridge from the seaside community in Garðabær to the inland nature preserve, providing new connections to the so-called Green Scarf - a continuous natural landscape wrapping the Reykjavik capital area.

Another objective was to design a neighbourhood that would fit into, and work with, the unspoiled surrounding landscape, and to integrate the built environment with nature. The site encompasses a hill that rises some 50 metres above a lava field, wetlands, and a portion of a pristine lake, in total 100 hectares. The lake was also to be protected by the plan, both in terms of the cleanliness of the water and in relation to the water level. A Sustainable Urban Drainage System was used in the neighbourhood, as traditional drainage solutions would result in a loss of water catchment area and the shrinking of the lake itself. The drainage system maintains the natural hydrology of the site and ensures that rain falling within the catchment area will feed the lake naturally.

Using environmental directives, nature protection codes, climate goals and water protection acts, and including them in the local detailed plan for the area, a new neighbourhood was created along with large natural green areas that, as a result of being incorporated into the local plan, was established as a protected green zone.

\section{Norway}

The Norwegian planning system is mainly framed by the Planning and Building Act (LOV-2008-06-2771). When it comes to (urban) green areas, there are other Norwegian laws which have some relevance: the Nature Diversity Act (LOV-2009-06-19-100), the Outdoor Recreation Act (LOV-1957-06-28-16), the Cultural Heritage Act (LOV-1978-06-09-50) and the Public Health Act (LOV-2011-06-24-29). In Oslo, there is also an Act concerning nature areas in Oslo and nearby municipalities (LOV-2009-0605-35), which can be influential.

Two ministries are the most important ones when it comes to urban green areas: first, the Ministry of Local Government and Modernisation is responsible for the Planning and Building Act, and 
second, the Ministry of Climate and Environment who is responsible for overseeing the Nature Diversity Act, the Outdoor Recreation Act, the Cultural Heritage Act, and the Act concerning nature areas in Oslo and nearby municipalities. The Ministry of Health and Care Services is responsible for the Public Health Act. Also, the Norwegian Environment Agency is tasked with relevant responsibilities regarding environmental issues and green structures. For example, the Agency produced guidance (Veileder) in 2014 called 'Spatial planning of green structures in cities/towns and urban settlements' (Miljødirektoratet, 2014 - see more below).

\section{Legislation}

Planning and Building Act (LOV-2008-06-27-71)

Spatial planning in Norway can be enacted at all three levels of government (national, regional and local). All levels have legally binding planning instruments ${ }^{2}$ at their disposal, and this can have different implications for urban green areas. In general, there are four national, five regional and three municipal/local planning instruments. Some are legally binding, others are not. In brief, the municipal master plan and the detailed/zoning plans are the planning instruments through which urban green areas are mainly regulated, particularly since 2008. For this reason, the following sections will focus on the municipal level, but with examples of two relevant national planning instruments (see below).

'Green structure' as a legal concept

Most important for urban green areas is perhaps that the Planning and Building Act, which introduced a new legal concept in 2008 called 'green structure' (grønnstruktur). It is regulated by $\$ 11-7$ (municipal plan) and \$12-5 (detailed/zoning plan) as one of six land-use objectives (arealformål). Briefly, green structure consists of four sub-objectives: nature areas, green corridors, recreation areas, and parks (see \$11-7 and \$12-5). Green structures can also be secured as a zone requiring special consideration (hensynssone), depending upon the planning level and the relevant implementation measures.

2 But in practice it is the municipal master plan and detailed/land use plans that are the most readily employed as legally binding planning instruments.
Green structure as land-use objectives (arealformål)

- The municipal master plan: "The land-use element of the municipal master plan shall to the necessary extent show the land-use objectives indicated in nos. 1 to 6. The main objectives may be broken down into the indicated sub-objectives as required" (\$11-7).

- The detailed/zoning plan: "Land-use objectives shall be indicated for the entire area under planning. Land-use objectives may be divided into subobjectives and may be combined with one other and with zones requiring special consideration" (\$12-5).

This means that land-use objectives will be indicated, often on a map, for the entire area under planning, but for the municipal plan, this will be done only to the extent deemed necessary. However, as there are six land-use objectives, there is no guarantee that 'green structures' will be identified for the area under planning. Yet they are still defined as a land-use objective and are, therefore, acknowledged as one specific aspect to consider throughout the entire planning process.

\section{'Green structure' as zones requiring special consideration (hensyssone)}

The municipal master plan's land-use element shall also outline zones requiring special consideration (hensyssone): "To the extent necessary, the land-use element of the municipal master plan shall indicate the considerations and restrictions that affect the use of land. [...] [They] shall be characterised in the land-use element as zones requiring special consideration with associated guidelines and provisions. Several zones may be indicated for the same land." (\$11-8) Green structures can be secured by using the second paragraph $\mathrm{c}$ ).

For the detailed/zoning plan, the zones requiring special considerations stipulated in the municipal master plan shall be used as the basis for preparing a detailed zoning plan. These zones may be continued in the zoning plan, or they may "be incorporated in land-use objectives and provisions that safeguard the purpose of the zoning plan" (\$12-6).

\section{What does green structure mean as a legal} concept?

In general, the Norwegian Environment Agency notes that, according to the Planning and Building Act, green structure must be established as a sole object. In other words, green structure is a landuse objective in both the municipal master plan 


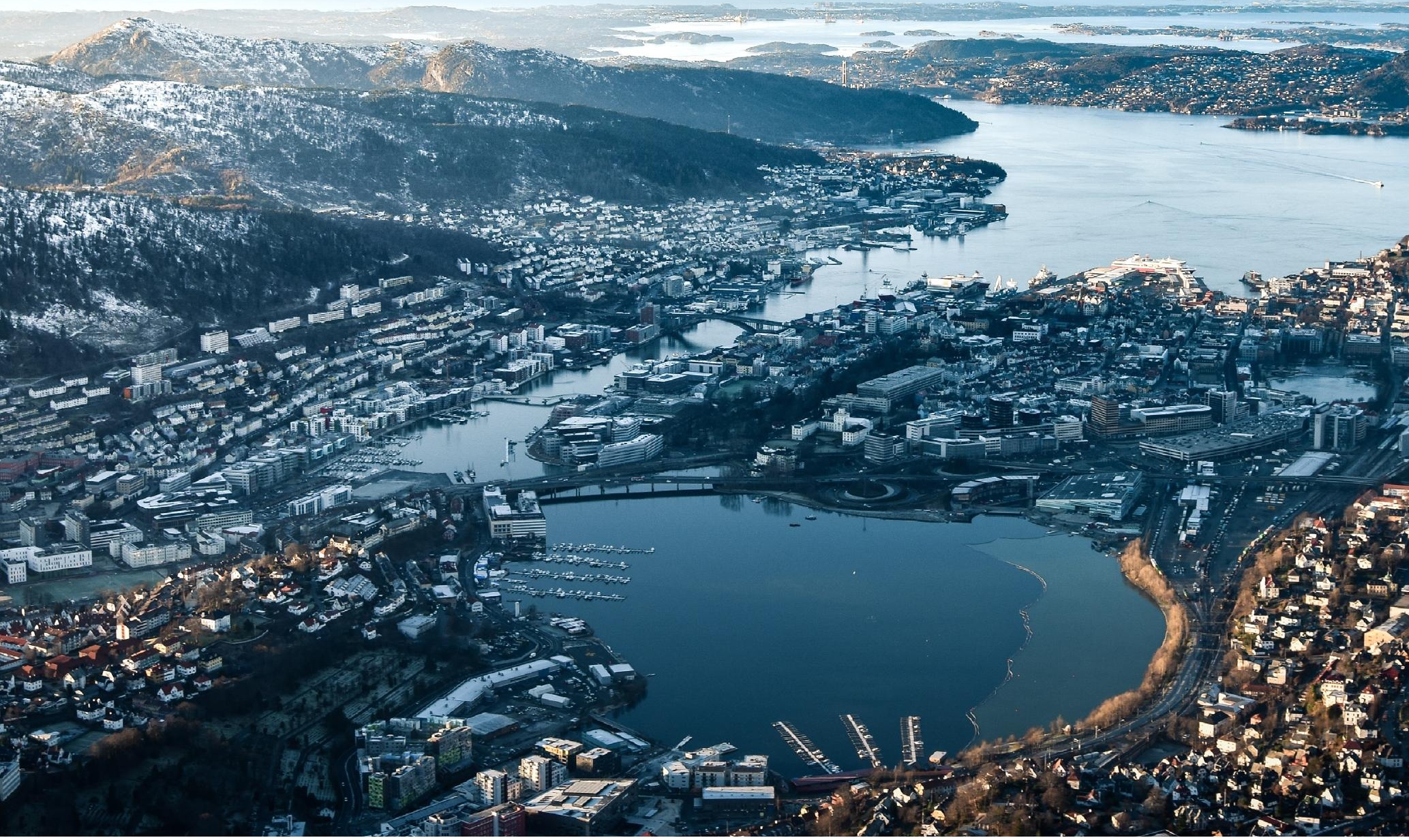

Bergen. Photo: Lachlan Gowen/Unsplash

and in the detailed/zoning plan, as well as a consideration that can be secured regardless of the land-use objective - that is, in terms of a zone requiring special consideration (Miljødirektoratet 2014). So, one way or another, green structure must be integrated into the planning work of the land-use element of the municipal master plan. This requires green structures to be an important theme from the very beginning, and in the early stages of the planning processes - that is, when the planning process is initiated, and the goals for the planning work are being formulated (Miljødirektoratet 2014).

What should green structure be used for?

According to the Norwegian Environment Agency, in practice green structure as a land-use objective must be used to safeguard and to develop 1) continuous greenery, 2) parks or other green areas, and 3) other large and small nature areas in the construction zone (Miljødirektoratet 2014).
General provisions relevant for green structure

For the municipal master plan, section 11-9, points 5 and 6 , as well as section 11-11, are also relevant for green structure. In \$11-9 it says that "the municipality may, independently of land-use objectives, adopt provisions for the land-use element of the municipal master plan regarding six points. This applies, for example, to play areas, public outdoor areas and small public squares" (\$11-9:5) plus "nature, landscapes and green structures" (\$11-9:6). This means that the municipality may adopt provisions for the land-use element of the municipal plan that are of importance for green structures regardless of the land-use objectives (arealformål) - in other words in zones with other land-use objectives.

In \$11-11, it stipulates that, in addition to regulations in \$11-7 nos. 5 and 6, provisions may be made (to the extent necessary) regarding seven specific points; for example, provisions to protect and maintain border vegetation within the shoreline areas (within 100 metres). 
For the detailed/zoning plan, the plan may, to the extent necessary, include provisions concerning land-use objectives and zones requiring special consideration (\$12-7). Especially relevant for urban green areas are provisions about installations and outdoor areas, the environment, and the particular needs of children for play and public outdoor areas (§12-7:4), as well as provisions to safeguard particular habitat types and other valuable natural assets (§12-7:6).

Other relevant regulations in the Planning and Building Act

There is a general shoreland protection which can limit the development of, for example, buildings within 100 metres of the shoreline (\$1-8). However, in a central government planning guideline (statlige planretningslinjer) from 2011, it has been clarified that this regulation may be applied differently in different municipalities throughout Norway (Kommunal og- moderniseringsdepartementet, 2011).

As in other Nordic countries, the municipal plan (which in Norway is legally binding) must secure municipal, regional and national goals together (\$11-11). In other words, it must successfully outline how these have been considered and safeguarded. A particular national planning instrument which includes national expectations is one called the National expectation regarding regional and municipal planning. But the central government planning guidelines are also, to some extent, influential here (see examples 1 and 2 ).

In addition to this, all planning, according to this Act, must consider climate change in terms of the reduction of climate emissions, but also through climate adaptation measures (\$3-1). In practice, this can have implications for urban green areas when it comes to stormwater and other related issues. In line with this, it is particularly important that spatial planning is following general requirements regarding assessments, as outlined in the fourth chapter. For example, it is necessary to produce a planning programme as the basis for planning work if the regional, municipal, and detailed plans could have a significant impact on the environment and society (§4-1).

The Nature Diversity Act (LOV-2009-06-19-100) The Nature Diversity Act is most relevant when it comes to protecting and preserving the natural environment from interventions. It says: "The pur- pose of this Act is to protect biological, geological and landscape diversity, and ecological processes, through conservation and sustainable use [...]" (§1). Most important for spatial planning are protected areas (områdevern), regulated by the fifth chapter of this Act. In practice, these protected areas may often be situated on the outskirts of urban areas, as well as in rural areas, but the Act is not limited to any specific territory.

As in all other Nordic countries, there are different types of protected areas - such as national parks (§35), protected landscapes (§36), nature reserves (§37), habitat management areas (§38) and marine protected areas (§39). In Norway, individual protected areas (in sections 35 to 39 ) "will be established by the King in Council, by means of regulations" (\$34). At the moment, there are about 3,000 protected areas in Norway. They cover around $17.4 \%$ of mainland Norway (Miljødirektoratet 2019).

The Outdoor Recreation Act (LOV-1957-06-28-16) The Outdoor Recreation Act is, in this context, perhaps most relevant when it comes to the Right to Public Access and to safeguarding recreational outdoor areas (e.g. \$1). This would include, for example, protecting the public from illegal fencing on uncultivated land. Also, in the Planning and Building Act, the relatively new legal concept of 'green structure' (from 2008) defined four sub-objectives (see above), of which recreation areas and nature areas are two. This has led to the notion that green structure as a legal concept can be used in the municipal master plan to strengthen connectivity between green areas, from urban centres to the surrounding rural areas. In this study, however, we will not be examining whether that has been the case in practical terms since the legal concept was first established in 2008.

Even though the Outdoor Recreation Act is not restricted to either urban or rural areas, it may have an implicit focus on outdoor recreation spaces outside inner urban centres. This is due to its provisions concerning rights and obligations when it comes to bathing, for example (§8), or to picnicking and tenting (§9). But as the Act is applied in both urban and rural areas, the right to access bathing is certainly also a right in (or in proximity to) urban settings, particularly on the shoreline and in blue-green areas.

When it comes to improving the accessibility of outdoor recreational areas, the Act stipulates that municipalities with uncultivated land may 
mark hiking trails and routes, as well as building bridges and taking other measures to facilitate access along these routes ( $\$ 35)$. In practice, this legislation is important to secure the Right to Public Access. In combination with, for example, the Planning and Building Act, it can also be used to create walking and hiking paths from urban centres to routes in surrounding rural areas. This can be done, for instance, by establishing hiking paths with clear signs, bridges and other important features which pass through areas of green structure defined according to the municipal master plan, and which end with hiking routes in surrounding rural areas.

\section{The Public Health Act (LOV-2011-06-24-29)}

The Public Health Act places an emphasis on municipal responsibility for public health, both generally and also in spatial planning. The Act's purpose is to "contribute to societal development that promotes public health and reduces social inequalities in health. Public health work shall promote the population's health, its wellbeing, and good social and environmental conditions, and which should contribute to the prevention of mental and somatic illnesses, disorders or injuries" (\$1). Moreover, the Act says that municipalities "shall have sufficient overview of the population's health, and the positive and negative factors that may influence this" (§5). In the same section, it outlines the way that the municipalities "shall identify public health challenges in the municipality, including an assessment of impact, and causal factors" (\$5). This means that the municipality must have an overview of how the supply (or lack of supply) of green areas, as well as the provision of walking and cycle paths, affects public health (Miljødirektoratet 2014).

In section 6, the connection is drawn explicitly with regard to spatial planning. It says that, in accordance with section 5 , public health challenges shall be included as a basis for working with the planning strategy (§6). More importantly, and also to be set out in the municipal master plan, "the municipality shall define the overall goals and strategies for public health that are appropriate for meeting the challenges facing the municipality" (§6). In other words, as has also been noted by the Norwegian Environment Agency, spatial planning for green structure in urban areas should correspondingly be integrated as part of this municipal work, in order to deal with local challenges to public health (Miljødirektoratet 2014).
Act on nature areas in Oslo and nearby municipalities (LOV-2009-06-05-35)

This Act only applies in Oslo and its neighbouring municipalities. It aims to promote and facilitate outdoor recreation, experiences of nature, and sporting activities (1§). The Act focuses on the fifth land-use objective in the Planning and Building Act, namely agricultural, nature and outdoor recreation, which in the planning legislation are areas that also allow for dispersed housing, holiday homes, etcetera. According to this Act, the fifth land-use objective offers limited options in allowing for such developments (see 5§, for example), and explicit permission from the ministry is mandatory in beginning the process of elaborating a municipal or detailed plan.

\section{Cultural Heritage Act (LOV-1978-06-09-50)}

It is also worth mentioning the Cultural Heritage Act, which has as its purpose the protection of archaeological and architectural monuments and sites, and of cultural environments in all their variety and detail (\$1). In the section where cultural environments, monuments and sites are defined, it is also noted that when assessing conservation value, emphasis can be put on those important natural values associated with cultural environments and monuments ( $\$ 2$ ). This means that important green values in urban cultural environments can be subject to protection as part of important cultural environments.

The Directorate for Cultural Heritage notes on its website that green areas which are humanly made, that is created by people (such as parks and gardens), constitute a special type of cultural monument - because they consist both of manufactured elements and also cultivated nature (Riksantikvaren, n.d.). These areas, which are part of built-up environments such as cities and towns, are, therefore, important to the preservation and management of such areas. That is, they are crucial in terms of preserving them as specifically humanly created 'natural areas' (Riksantikvaren, n.d.). It is, therefore, important both to preserve and maintain these areas as prominent cultural environments: ones which could be subject to protection under the Cultural Heritage Act if they are deemed to be associated with important cultural environments and monuments. 


\section{Policies and objectives}

In Norway, the laws outlined above constitute the principal legal framework by which green urban areas might be developed, protected and furthered. Examples 1 and 2 below outline two additional national planning instruments and policy documents, set out through the Planning and Building Act, which may be influential in this regard. However, there are also various White Papers, or so-called 'messages to the parliament', known as stortingsmeldinger. These documents provide guidance for spatial planning and urban green areas. Some of these White Papers are listed below as further reading. The following section focuses on yet another guiding document on green structure, dating from 2014 and the Norwegian Environmental Goals.

\section{Spatial planning of 'green structure' in cities/} towns and urban settlements

This is a guidance document which was produced in 2014 by the Norwegian Environment Agency. Its focus is on the relatively new legal concept (at that time) of 'green structure', which was introduced in the Planning and Building Act of 2008.

The guide illustrates how various relevant analyses may be carried out, and it reviews topics of concern to spatial planning. The guidance focuses on the overall 'green structure' of a construction zone (byggesonen). That is, it looks at areas which may be included on the map of a municipal master plan as a land-use objective (arealformål), or as a zone requiring special consideration (hensynssone), depending upon the planning level and relevant implementation measures involved. This guidance also illustrates how municipalities can work with targeted and knowledge-based planning in order to further protect and develop the green structures of particular cities and towns (Miljødirektoratet 2014).

In the guidance provided, the four sub-objectives of green structure are further explained and interpreted. This can be used as a basis for the planning work carried out by municipalities:

Nature areas: Green areas with preserved natural features, preferably with original native vegetation. They can be easily adapted for passage, have a great diversity of vegetation, and can be important areas for wildlife, for example.

- Green corridors: Coherent green structure in the construction zone, including hiking and possible trail connections that provide opportunities for continuous walks in natural surroundings. They can connect parks, recreation areas and nature areas, and can also provide connections to other land areas, links to the shore zone, and so on.

- Recreation areas: Green areas which are widely used, adapted and designed for contemporary play and physical activity, as well as for relaxing vacation and outdoor activities. They may include natural or cultivated tree vegetation, and the ground should often be reinforced to withstand heavy use.

- Parks: Green areas which are landscaped and consciously designed to include architectural qualities, often as an urban or historical feature. Cultivated vegetation, often with large spaceforming trees, is included. There is a high level of facilitation for passage and related activities. Elements of fountains and sculptures may be present. (Miljødirektoratet, 2014).

This guidance on green structure concerns the application of the legal concept of 'green structure' in planning practice, and is, therefore, of more relevance than many other policy documents, particularly when it comes to understanding the legislation in relation to urban green space. For example, the national document Byrom - en idehåndbok (Kommunal- og moderniseringsdepartementet, 2016) is more a collection of good examples to inspire municipalities, rather than a policy document which municipalities and counties need to relate to in regard to legislation. In Norway, there are several policy and political documents that also have some importance for urban green space. These are listed below, as further reading.

\section{Norwegian Environmental Goals}

There are 23 environmental goals existing in Norway. They are categorised under six areas: 1) Natural diversity; 2) Cultural heritage and cultural environment; 3) Recreational outdoor life; 4) Contamination and pollution; 5) Climate, and 6) Polar/Arctic areas (see Miljødirektoratet, n.d.). Even though the goals are not necessarily mutually exclusive, and indeed may be seen as interrelated, for urban green areas objectives 1 and 3 and their sub-objectives may be particularly relevant. For example, environmental goal 1.1. says that ecosystems shall be in good condition and provide 'ecosystem services' (Miljødirektoratet, n.d.). Even though this goal is focused on ecosystems in general, planning for green structures could help to achieve the goal, for example by strengthening connectivity between 
green areas in urban centres and the surrounding rural green and blue areas.

Another sub-objective worth emphasising is 3.1: "The position of outdoor recreational life will be safeguarded and further developed through safeguarding the Right to Public Access, preserving and facilitating important outdoor recreational areas, and stimulating increased outdoor activity for all" (Miljødirektoratet, n.d.). One of the indicators for this sub-objective is the share of the population with access to play facilities and outdoor recreation areas within 200 metres of where they live, which indicates the importance of establishing green structures in urban areas, too.

\section{Implementation and practical examples}

Example 1 - National expectations regarding regional and municipal planning, 2019-2023

This is a national planning instrument in accordance with the Norwegian Planning and Building Act. 'National expectations' are presented every four years. The main purpose of this is to present the Government's guidelines on the appropriate focus for counties and municipalities in their local planning, all with respect to national policies of importance. The character of this planning instrument is strategic and is not regulative in terms of being legally binding.

The latest national expectations document, published in 2019, consists of four main chapters. Each chapter ends with a list of emphasis points setting out the government's expectations (see Kommunal- og moderniseringsdepartementet, 2019a). In brief, the current national expectations focus most of all on integrating Agenda 2030 as a basis for regional and municipal planning. There is also a continued emphasis on 'compact city' ideals, and on densification measures close to public transit hubs. Urban green space is also outlined as an important national expectation, principally in the fourth chapter on 'Good urban living environments'. Examples of national expectations with relevance for compact city ideals and urban green space are the following:

- "The county and municipal authorities [should] facilitate high utilisation of space in urban areas through high-quality densification and transformation, with an emphasis on architecture, urban spaces, cultural environments, green structure and other environmental values in the local surroundings. The location of [buildings, services etc.] [...] is assessed in conjunction with existing or future public transport hubs." (Kommunal- og moderniseringsdepartementet, 2019: 23).

- "The municipalities [should] give priority to preserving urban spaces and blue-green infrastructure, with footpaths and trails that protect natural assets, aid surface water management and facilitate physical activity and contact with nature for all." (Kommunal- og moderniseringsdepartementet, 2019: 29).

- "The county and municipal authorities [should] safeguard the use and conservation value of watercourses in their planning. The potential of watercourses for safe diversion of surface water and nature-based flood prevention is [thereby] exploited." (Kommunal- og moderniseringsdepartementet 2019: 29).

Furthermore, urban green space is also emphasised as a potential solution to deal with stormwater and flooding. This can be achieved through measures such as safe flooding roads, more green areas where water can drain to the ground, and green roofs and walls (Kommunal- og moderniseringsdepartementet, 2019).

\section{Example 2 - Central Government planning} guidelines: three examples

Central government planning guidelines aim to provide guidance or regional and local plans, and to propose issues of particular national importance (see the Planning and Building Act: §3-5 and §6-2). They can also be used to give concrete expression to national expectations regarding regional and municipal planning, as well as important policy areas in spatial planning (Kommunalog moderniseringsdepartementet, 2019b). The three latest ones, set out below, are examples of guidelines which could all have implications for green-blue spaces in urban areas.

The latest one is from 2018 and relates to climate and energy planning, as well as climate adaptation (Kommunal- og moderniseringsdepartementet, 2018). In brief, it states that the government, regions and municipalities shall use spatial planning to stimulate and contribute to reducing greenhouse gas emissions. It should also contribute to the sense that society is prepared to face the challenges of climate change through climate adaption measures. It is in this context that the need for overarching green-blue structures are mentioned as something that all plans should consider. 
The second one is from 2014 and relates coordinated housing, land, and transportation planning (see Kommunal- og moderniseringsdepartementet, 2014). It has one objective: to promote the development of the compact city, for example through strategies to densify population around public transit hubs. This is an example of how a national planning instrument can, at the same time, frame the current planning discourse about densifying cities around transit hubs.

The third example is from 2011 and is concerned with differentiated management of the shoreline (Kommunal- og moderniseringsdepartementet, 2011). In this guideline, shoreline protection is clarified as being applied differently in a variety of municipalities. Or this purpose, Norway is recognised as being divided into three main areas: 1) coastal municipalities in the Oslo fjord region, 2) other areas where the pressure on land use is considerable, and 3) areas with less pressure on land use. The purpose of this guideline is to encourage a stronger geographical differentiation, whereby protection is rendered most stringent in central areas where the pressure on land use is greatest.

\section{Example 3 - Blue-green area factor}

Nowadays, some municipalities are working towards introducing a planning tool called the bluegreen area factor, in order to ensure the presence of green areas in the built environment, in cities and towns. This tool calculates how, for example, green areas are safeguarded according to a particular formula (Miljødirektoratet, 2014). The Norwegian Environment Agency notes that in the land-use element of a municipal master plan it is possible to set a few requirements for different types of areas, specifically in relation to this 'bluegreen area' factor. However, "the blue-green area factor cannot replace the functional requirements of the land-use element" in a municipal plan, with regard to coherent green structure, the coverage of different types of green areas, natural diversity, landscaping, etcetera. (Miljødirektoratet, 2014).

In practice, this is done both in the municipal master plan and in the detailed/zoning plan, by utilising the following sections of the Planning and Building Act (email correspondence with a regional planner in Hordaland, October 2019):

Municipal Master Plan:

- \$11-7, Land-use objectives in the land-use element of the municipal master plan.
\$11-8, Zones requiring special consideration.

§11-9, General provisions relating to the landuse element of the municipal master plan, especially points 5 and 6 .

- \$11-11, Provisions regarding land-use objectives pursuant to section 11-7, numbers 5 and 6 .

Detailed/zoning plan:

- \$12-5 Land-use objectives in a detailed/zoning plan.

- \$12-6 Zones requiring special consideration in a detailed/zoning plan.

- § 12-7 Provisions in a zoning plan, especially points 4 and 6 .

It is also common for municipalities to create more general (but detailed) guidelines or quality standards for the requirements of blue-green structures that the developer must pay attention to. But it should be noted this comes as a supplement to legally binding regulations, and its chief function is to clarify them. It has also become more common to require open water surfaces and buffers against extreme rainfall (email correspondence with a regional planner in Hordaland, October 2019).

\section{Example 4 - Voss municipality - green structures in the city centre}

Voss municipality is an example of a relatively small municipality that, in recent years, has worked progressively with its green structures in the city centre. In the land-use element of the municipal plan from 2015 (Voss kommune 2015) it says that, according to $\$ 11-7$ and $\$ 11-10$ no. 3 in the Planning and Building Act, green structures shall be secured in the city centre and along the shoreline. It further stipulates that a detailed plan must clarify the borders of the city centre, which should also be developed through an urban structure which (at the same time) makes use of the most valuable green areas - that is, by developing the city centre with a combination of urban and green qualities.

Prior to the detailed plan, the municipality decided that there was also a need to develop a planning programme. The planning programme was consequently adopted in 2018 (Voss Kommune, 2018). It further examines the question of how to develop the urban centre to become a truly living 'local city centre', with a focus on green transition and sustainable development. The plan also needs to secure important green structures, and facilitate access to nature as a resource and for recreational 
purposes. There are other objectives, too, such as high-quality densification and good public spaces (see more in Voss kommune 2018). The planning process for the detailed plan is ongoing, and the first proposal of the detailed plan was put to a public hearing during the autumn of 2019. The proposed map of the land under planning, including its land-use objectives, has clearly put an emphasis on green structures (Voss kommune 2019a). The description of the planning proposal also stresses the need to connect the city centre to both water areas and green areas (Voss kommune 2019b). Since the planning process still is ongoing at the time of writing, what will happen remains to be seen.

\section{Further reading and other important political and policy documents in Norway:}

Action Plan for Outdoor Recreation life.

[Handlingsplan for friluftsliv]: https://www. regjeringen.no/contentassets/ce805bbda07b4 Od184115b512d1cOdeO/t-1564.pdf

National policy guidelines for children and spatial planning [Rikspolitiske retningslinjer for barn og planlegging]: https://lovdata.no/dokument/ SF/forskrift/1995-09-20-4146?q=barn\%20 og\%20planlegging

White Paper to parliament concerning sustainable cities and strong districts. [Melding til Stortinget om bærekraftige byer og sterke distrikter]: https://www.regjeringen.no/ id2539348

White Paper to parliament on the outdoors recreational lives - nature as a source of health and quality of life. [Melding til Stortinget om friluftsliv - natur som kilde til helse og livskvalitet]: https://www.regjeringen.no/ id2479100

White Paper to parliament concerning public health - the good life in a safe society. [Melding til Stortinget om folkehelse - gode liv i eit trygt samfunn]: https://www.regjeringen.no/ id2639770

White Paper to Parliament concerning nature for life - the Norwegian action plan for natural diversity. [Melding til Stortinget, natur for livet - norsk handlingsplan for naturmangfold]: https://www.regjeringen.no/id2468099

Mapping and valuation of outdoor recreation areas. [Kartlegging og verdsetting av Friluftslivsområder]: https://www. miljodirektoratet.no/globalassets/ publikasjoner/M98/M98.pdf

\section{Sweden}

The Swedish planning system is framed by two main pieces of legislation: the Planning and Building Act (SFS, 2010:900) and the Environmental Code (SFS, 1998:808), which consists of regulations with regard to developing, preserving and protecting both land and water areas. These two laws, as well as some important national goals, are particularly important when it comes to developing, preserving and protecting green qualities in urban areas. The national agency responsible for the themes outlined in this report is mainly the Swedish National Board of Housing, Building and Planning (from now on, Boverket), which is the Swedish national planning agency. Another important agency in this respect is the Swedish Environmental Protection Agency. Also the County Administrative Board, which is the national authority operating at regional level, and which has the responsibility of ensuring that national interests are observed in municipal planning.

\section{Legis/ation}

The Planning and Building Act (SFS, 2010:900)

By considering the freedom of the individual person, the Planning and Building Act in Sweden aims to promote the development of the society along the lines of equality and a good standard of living. But it is also there to promote long-term sustainable living conditions: ones which are good both for those alive today, and for those who will be here tomorrow. In other words, the Act as a whole aims to promote sustainable development for current and forthcoming generations.

Individual, public and national interests Spatial planning, according to this Act, shall consider both individual and public interests (SFS, 2010:900, chapter 2 , §1). This is crucial when applying the legislation, and the entire second chapter of the Act outlines regulations with regard to individual and public interests. A major difference between individual and public interests is that the Act is relatively clear about what counts as public interests, but it does not list any specific individual interests. In addition, there are "regulatory national provisions specifying geographic areas of national interest [...]. National state agencies, such as the Swedish Transport Administration can thus designate areas of national interest. Both the mandate to designate such areas and the areas them- 


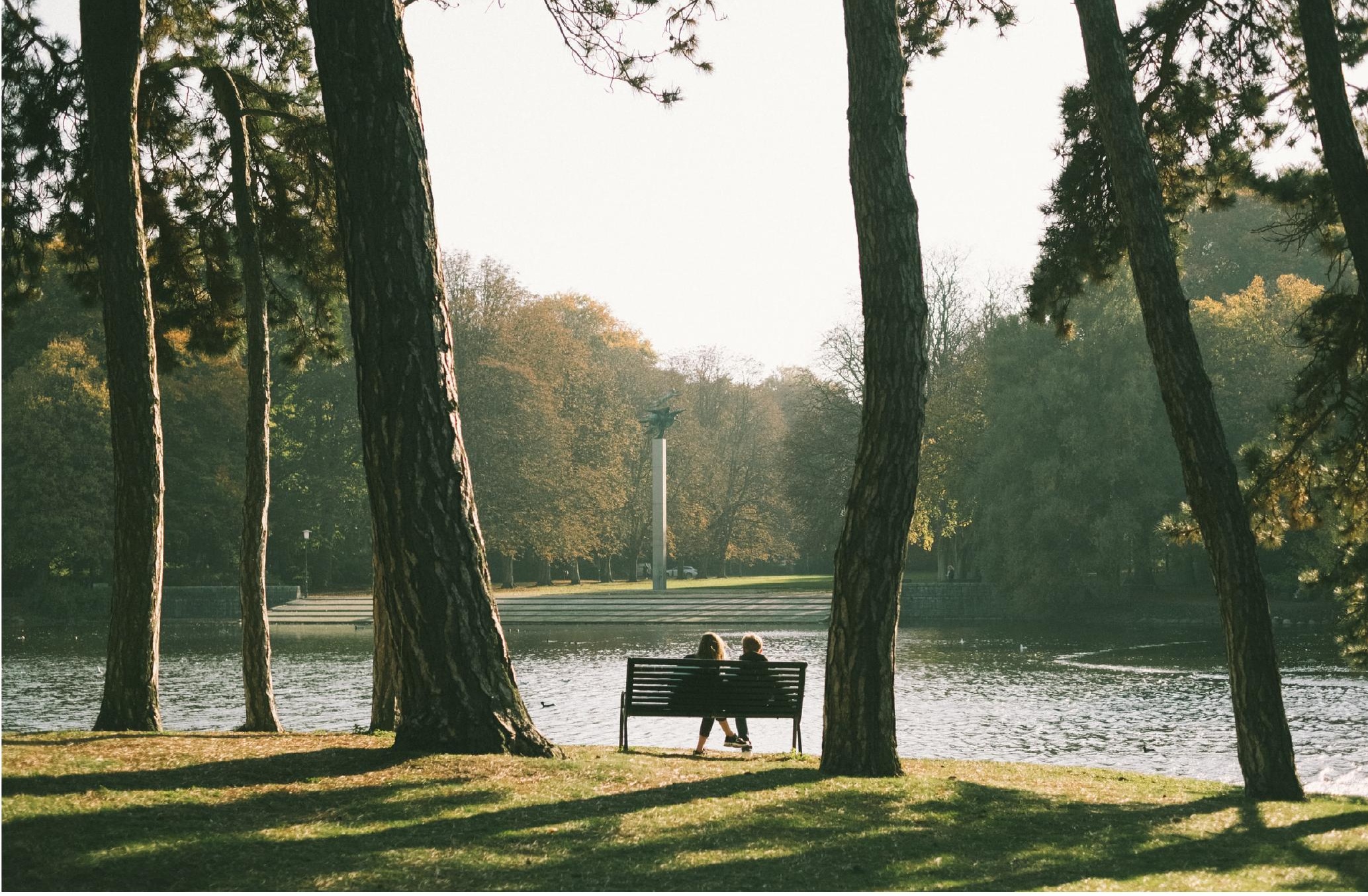

Malmö. Photo: Jonas Eriksson/Unsplash

selves have direct implications for local and regional planning." (Smas and Lidmo, 2018: 24).

In the decree about custody for land and water areas (SFS, 1998:896), regulations are outlined concerning the division of responsibilities between agencies. They are to produce planning material in terms of the national interest, which in turn could and should influence the protection, preservation, and development of green areas. One example is the national interest in furthering recreational purposes and in nature management (see, for example, SFS, 1998:896, §2). Moreover, the Planning and Building Act refers directly to regulations about custody for land and water areas. These are set out in the third and fourth chapters of the Environmental Code (see more below). These regulations are there to be applied for planning carried out in accordance with the Planning and Building Act (SFS, 2010:900, chapter 2, §2). For example, whole areas of concern are defined as existing in 'the national interest' in the fourth chapter of the Environmental Code (see SFS, 1998:808, chapter $4, \S \S 2-6)$, such as the coastal area in Halland. In these areas, development is highly restricted. Yet it is also stated that these broad areas of national interest do not constitute an obstacle for the development of "already existing urban areas/settlements" (SFS, 1998:808, chapter 4, §1).

Another crucial term in the Planning and Building Act is the Swedish term lämplig (suitable or appropriate): "When planning, and in cases of granting building permits [...] land may be used for new development only if the land, from a public point of view, is suitable for the purpose" (SFS, 2010:900, chapter 2, §4).

This means that spatial planning in Sweden must examine, and argue for, new land use in terms of whether the land is suitable for the new purpose from a 'public interest' point of view. Further, the second chapter of the Act outlines other issues that need to be considered in the context of spatial planning. One example concerns the following:

When planning according to this Act, there is a need to take into account whether there exist any of the following, within (or in close proximity to) areas with cohesive buildings: 
1. streets and roads,

2. squares,

3. parks and other green areas,

4. suitable sites for play, exercise or other outdoor activities, and

5. possibilities for providing a reasonable public service and a reasonable commercial service (SFS, 2010:900, chapter 2, § 7).

Even if several issues need to be considered as part of spatial planning, according to this Act, of particular relevance for green values in urban areas is the fact that that there is a requirement to take into account the need for parks and other green areas; and also the need for sites of play, exercise and other outdoor activities in proximity to cohesive built-up areas. In the Environmental Code a similar regulation exists, which puts extra emphasis on the need for green areas particularly "within, or proximate, to urban areas" (see more below, and in SFS, 1998:808, chapter 4, §6). However, there is no specific definition of what "proximity to green areas" means in the legislation, which illustrates the unavoidable fact that it is very much contextdependent. In this case, it is up to the specific planning project to examine proximity to green areas in each specific case.

Green areas in different planning instruments In Swedish spatial planning, there are many goals that need to be considered by the municipality and by the public authorities, all of which will impact the sustainable development of the municipality. According to Boverket (2011), there are 21 different policy fields that all are of importance for spatial planning, and around 28 different national agencies who are responsible for the some 100 national goals - all deemed relevant for spatial planning. To give concrete expression to national goals, spatial planning at regional and local levels is very important. It is necessary to implement these goals at those levels, but at the same time, it must be recognised that this puts considerable pressure on the planning authorities to coordinate efforts and to compromise between different goals by using the available planning instruments wisely.

In the regional plan (see SFS, 2010:900, Chapter $7, \S 3$ ) produced by a specific region (only in Stockholm and Skåne, in this case), it should be noticed how the regional plan has taken public interest into consideration, but also national interests. As outlined above, these could have significant implications for urban green areas. On its website, Boverket has also produced guidelines and information for ecosystem services, which are of definite importance for green (urban) areas. For example, it is stipulated that the regional plan could identify structures of overarching importance for the proper functioning of ecosystem services (Boverket, 2018a). Also, every County Administrative Board (not the region per se) is today developing regional action plans ${ }^{3}$ for green infrastructure (Boverket, 2018a; Naturvårdsverket, 2019a). At regional level these could obviously have implications for green urban areas.

In general, the regional plan may have implications in relation to specific urban development projects, due to the fact it is advisory for the municipality's comprehensive plan, which in turn is advisory for legally binding detailed plans. The municipality's comprehensive plan needs to indicate how public interests are met, as well as the national interests specified in the Environmental Code (see for example SFS, 2010:900, chapter 3, §§4-5). The municipality's comprehensive plan also needs to indicate how the plan coordinates overall, and how it considers relevant national and regional goals, plans, and programmes which are of importance for the sustainable development of the municipality. Moreover, the municipality's comprehensive plan shall indicate the general structure of land and water areas (SFS, 2010:900, chapter $3, \S 5)$. This means that green corridors, green infrastructure, and other ecosystem services could need to be pinpointed in the general structure of the municipality's comprehensive plan. Since 2018, the municipality's comprehensive plan shall also outline risks and related strategies concerning land erosion, flooding and other climate adaptation measures and challenges (SFS, 2010:900, chapter 3 , §5). Here, nature, parks and other green areas can play a major role (see also Boverket, 2018a).

A detailed plan can be preceded by a planning programme which, according to the Act, shall be produced if the municipality makes an assessment that it would facilitate the planning process for elaborating the detailed plan. In a planning programme, the departure points and the goals of the plan shall be outlined by the municipality (SFS, 2010:900, 5 Chapter, 10§). According to Boverket, the planning programme together with the munic-

3 Not a planning instrument in the Planning and Building Act. 
ipality's comprehensive plan are the most important planning instruments to integrate ecosystem services (Boverket 2018a). Perhaps, the planning programme is the most important instrument as it often covers a larger area than the detailed plan but a much smaller area than the municipality's comprehensive plan. Yet the planning programme could still identify and deal with strategic issues related to stormwater, green corridors and access to green areas.

A detailed plan shall, in general, be aligned with the municipality's comprehensive plan, as it is the only legally binding planning instrument in the Swedish planning system. So, based on the advice and guidelines in plans at the upper levels, as well as the planning programme and examinations during the planning process for the detailed plan, it shall regulate and specify the borders/ areas for public spaces, development districts (kvartersmark), and water areas. It shall also regulate the use and design of public spaces that the municipality is the principal agent for, and the use of development districts and water areas (SFS, 2010:900, chapter 4, §5). Public spaces are defined in the Act as a street, a road, a park, a square or another area that according to the detailed plan is intended to be used for common use (SFS, 2010:900, chapter 1, §4). For public spaces, the municipality has, in general, a good opportunity to regulate how the built environment and green spaces should be used, developed and preserved, thanks to the so-called 'attribute provisions', or egenskapsbestämmelser (see, for example, Boverket, 2018b). However, for development districts, the main provisions that can be regulated in a detailed plan relate to vegetation, the design of the ground surface, and its height (SFS, 2010:900, chapter 4, \$10). For instance, in practice, a permit for cutting trees within designated development districts can be regulated in the detailed plan, but the possibilities of requiring further development of ecosystem services in a detailed plan are limited in those same areas.

Moreover, other important regulations exist in the eighth chapter, which outlines various requirements on buildings, public spaces, and plots. For example, undeveloped plots that are intended for development must be arranged in a suitable way, in consideration of the urban and landscape image, and taking into account the natural and cultural values of that site (SFS, 2010:900, chapter 8, §9). This means that natural conditions should be considered sympathetically, as far as possible. Moreover, the detailed plan may also repeal shoreline protection (see more below; SFS, 2010:900, Chapter 4, \$17) and it may also regulate measures to protect areas from flooding (SFS, 2010:900, Chapter 4, §12). In turn, these provisions may have implications for green urban areas. Green areas and the natural environment can, however, be protected through other compensatory regulations specified in the Environmental Code. These will be outlined briefly below. However, as Boverket (2019) concludes (on which, see more below), the current legal framework mainly considers nature and green space from the perspective of preservation, and there is a gap in the present legislation when it comes to developing new urban green spaces.

\section{The Environmental Code (SFS, 1998:808)}

The regulations in the Environmental Code aim to promote a sustainable development: one that assures current and future generations that they will enjoy a healthy, positive environment (SFS, 1998:808, Chapter 1, §1). In general, the Code regulates various ecological issues in terms of protecting nature and the environment, though some are evidently of more relevance than others as far as spatial planning and green urban areas are concerned.

Perhaps the most essential provisions are to be found in the third, fourth and seventh chapters. The third and fourth chapters stipulate regulations for the custody of land and water areas. In the third chapter, it says that "land and water areas shall be used for the purpose(s) that they are most suitable for, considering their nature/character, location and present needs" (SFS, 1998:808, Chapter 3, §1). The third chapter also regulates "specific land-use interests" (see SFS, 1998:808, Chapter 3, $\S \S 2-6)$. Perhaps the most important provision for urban green areas is the following:

"As well as the physical environment in general, land and water areas which are of significance from a public point of view, because of their natural or cultural values, or in consideration of recreation purposes, shall as far as possible be protected against measures that can damage the natural or cultural environment significantly. The need for green areas in urban settlements, or proximate to urban settlements, shall particularly be considered" (SFS, 1998:808, Chapter 3, §6).

In the fourth chapter, whole areas of national 
interest are defined (see SFS, 1998:808, chapter4, $\S \S 2-6)$. In these areas, development or interfering with the environment is highly restricted, unless it can be achieved without significant damage to natural and cultural values. However, those whole areas of national interest defined in chapter four (§§2-6) do not constitute an obstacle to the development of existing urban areas or settlements, unless otherwise stated in the specific regulation (SFS, 1998:808, chapter4, §1). There is one specific urban green area which is defined in $\S 7$ as an entire area of national interest, and which is, therefore, specifically protected from environmental interference. This is the Ulriksdal-Haga-Brunnsviken-Djurgården national urban park (see SFS, 1998:808, chapter 4, §7). In a national urban park, new development can only be carried out if it can take place without infringing in the integrity of the parkland or the natural environment, and without harming the historical landscape in terms of both its natural and cultural values. In Sweden, there is only one national urban park, compared to Finland, for example, where individual municipalities are nowadays actively working towards establishing their own national urban parks (see the Finnish case, above).

In addition, there are specific protections afforded to nature which, if was seen to be located within or in proximity to urban settings, might have implications for urban green areas. These are regulated by the seventh chapter of the Environmental Code. These concern, for example, national parks, nature reserves, cultural reserves, and biotopes - areas exhibiting uniform environmental conditions - which are all protected areas (see SFS, 1998:808, Chapter 7). For instance, nature reserves can be established by the municipality or by the County Administrative Board with the aim of preserving, protecting or maintaining valuable natural environments, or in order to satisfy the human need for recreational areas suitable for outdoor activity. If a nature reserve is established, the decision to do this shall include an account of the measures needed to achieve its purpose as a reserve, which might mean the prohibition of new buildings, and so on (SFS, 1998:808, chapter 7, §§4-5). In other words, nature reserves established in urban areas could offer protection from further development to these areas, and therefore preserve green areas and green values within, or in proximity to, urban settings (see the example from Örebro municipality, below).
Chapter 7 also addresses special protection for shoreline areas, which regulates change and development within 100 metres (in some cases up to 300 metres) of the shoreline (see SFS, 1998:808, chapter 7, §§13-18). This particularly affects green-blue areas. For example, within protected shoreline areas, new buildings cannot be constructed, and the use of existing buildings may not be re-designated. There are also measures to prohibit anything that essentially alters the living conditions of flora and fauna (SFS, 1998:808, chapter 7, \$15). In a detailed plan, shoreline protection could be ended if particular conditions are applied, but only if there are good, defensible reasons for doing that (see SFS, 2010:900, chapter 4, \$17; chapter 7, \$18). The municipality's comprehensive plan, or a thematic issue arising from that plan, may also pinpoint exemptions to shoreline protection in areas which have particular importance for rural development. Additionally, it is worth mentioning that there are also regulations for protecting biodiversity in the eighth chapter of the Environmental Code (SFS, 1998:808, Chapter8).

\section{Is the current legal framework adequate?}

In a recent memorandum, Boverket (2019) has reported on the level and type of support for ecosystem services within the current legal framework. One conclusion is that there are gaps between various chapters in the Planning and Building Act. Ecosystem services seem not to be considered fully, and it has become more difficult to develop and preserve urban greenery in public spaces. This is due to increasing pressure towards densification, which impacts existing green spaces within cities. Designated development districts in the detailed plan have, therefore, become even more important for securing green areas in cities. Beyond those development districts, the current legal framework for securing green values is not strong enough.

According to the Boverket report (2019), both the Environmental Code and the Planning and Building Act tend to look at green values from the perspective of preservation and protection. This has meant, according to Boverket, that there is not enough support for nature and for urban greenery in terms of the kind of functional perspectives which would be most useful in setting the requirements needed to develop new green structures, for example on brownfield sites. 


\section{Policies and national goals}

There are many national goals which are relevant to urban green space. One is what could be called 'the generation goal', which aims to hand over a society to the next generation in such a way that the largest environmental issues have been solved without simply exporting environmental and health problems beyond Swedish borders (see Sveriges Miljömål, n.d.). Two indents of this 'generation goal', covering ecosystem services and biodiversity. They are about ensuring that:

1. Ecosystems have recovered, or are on the way to recovery, and their long-term capacity for generating ecosystem services is assured.

2. Biodiversity and the natural and cultural environment have been conserved, promoted and employed sustainably. (Sveriges Miljömål, n.d.).

Two of the current Swedish Environmental Quality goals are also important for ecosystem services, namely a good built environment and rich diversity in plant and animal life (see Sveriges Miljömål, n.d.). In addition to this, there are the Milestone Targets, four of which have proved particularly important for ecosystem services in built environments. Two of these remain to be fulfilled. First, the full integration of urban greenery and ecosystem services into urban environments (to be achieved by 2025); and 2) Methodologies appropriate to urban greenery and ecosystem services in such urban environments (to be achieved by 2020; see more in Naturvårdsverket, 2019c).

In 2017, a new Swedish goal for sustainable cities was established. It declared that "sustainable cities are inclusive and accessible urban environments; ones that offer all people an attractive and green habitat" (Boverket 2018c). Moreover, since 2012, Sweden has had ten goals for encouraging outdoor recreational purposes (see Naturvårdsverket, n.d.). Several of these entail accessibility to an attractive natural environment and to outdoor recreational areas - both in proximity to, or within, urban settings, as well as other areas further away (Boverket, 2018c). One of these goals involves enhancing the beauty of nature located near urban areas (swe. tätortsnära natur) (Naturvårdsverket, 2018).

Other relevant international targets in relation to ecosystem services include the seventh subsidiary goal within SDG goal 11, "sustainable cities and communities", and some further subsidiary goals within number 15 on that list, "life on land", which forms part of Agenda 2030. Another relevant goal mentioned by Boverket (2018c) is the UN's New Urban Agenda, particularly that which concerns "accessible, coherent and multi-functional green zones and green public spaces."

\section{Implementation and practical examples}

Example 1 - The green space factor in Malmö

Some municipalities in Sweden are now using a planning tool called 'green space factor'. Malmö has quite progressively worked with this tool, and as part of the ESPON GRETA project, it has been identified as an example of innovation and good practice (ESPON GRETA 2019; see also Malmö stad, 2017). The green space factor has been included as a part of the local authority's Environmental Building practice. What this means is that for every surface a developer wants to seal (buildings, asphalt or concrete), they will have to compensate for it by providing something else that is definitively green or blue. The green space factor is thereby intended to help secure a minimum number of green and blue spaces within new development areas.

The green space factor measures how ecosystem services are produced by green and blue environments. The tool has an emphasis on assessing noise and air pollution reduction and measures to achieve water purification. Both are especially important ecosystem services in cities. This is an example of a local policy and planning tool which can be readily utilised in planning practice. But according to the current legal framework, it is not possible to use the green space factor as a requirement in, for example, the designated development districts that feature in detailed plans.

\section{Example 2 - Densification project in Malmö}

The second example follows directly on from the green space factor in Malmö. It concerns a small densification project involving just one new apartment building, at the expense of a small amount of land in an existing small park that forms part of an area set aside for planning purposes. In the description provided in the plan (see Malmö stad, 2018), it mentions that close to the existing apartment buildings, south of the land under planning consideration (marked by red colours in Figure 1), there are further existing green areas; notably a large public park.

In the plan, it is proposed that the park in 


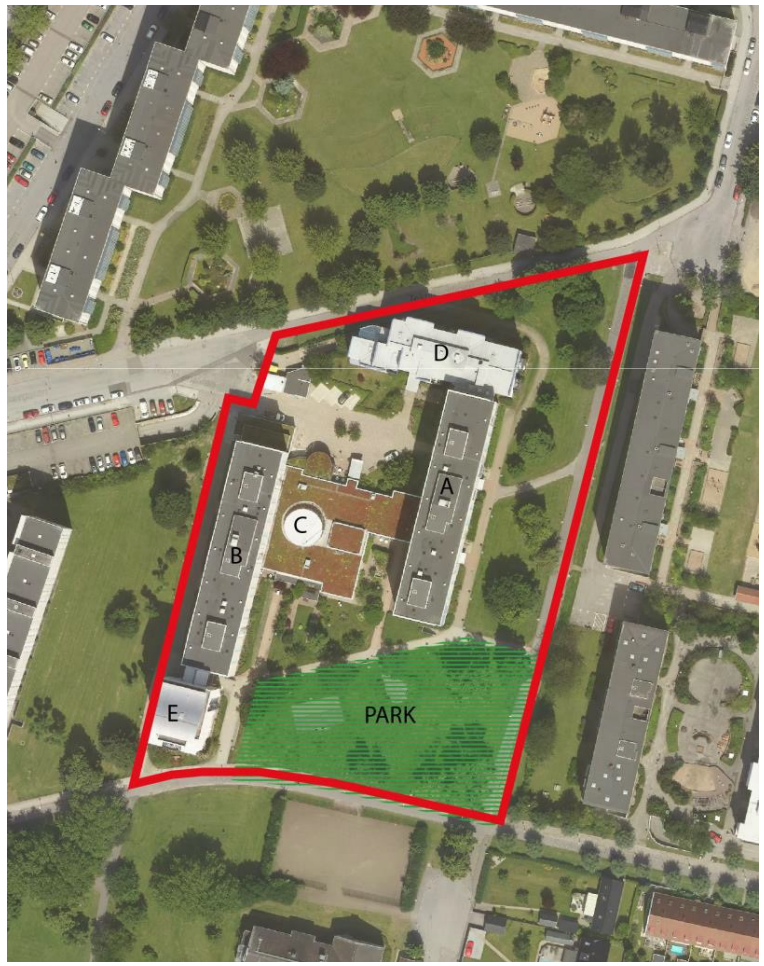

Figure 1: The land under planning consideration is marked in red. The land use prior to the development consists of a small park in the south, which will be slightly densified by the construction of one apartment building. Source: Malmö stad (2018: 3).

Figure 1 will be densified by one apartment building. The space of the park will thereby be reduced by around 550 square meters. Even though the amount of green space will have been reduced by this development, the assessment in this individual case is that the proximity of the building to green areas will be beneficial for both current and future residents. It is, of course, important that the park involved continues to be accessible and to be perceived as attractive and inviting. A proper investigation of compensation measures is clearly regarded as necessary in these circumstances, and it is important to consider the possibility of enhancing recreational values, biodiversity and stormwater treatment measures.

We should note that Malmö's 'green factor policy' has been attached to this particular plan, and is mentioned in its written presentation. Even though specific compensation proposals are not spelled out in the description contained in the plan, it is stressed that, based on a clear political decision, a compensation study must be completed in order to identify prominent measures to offset the reduction in size of the green area. These compensation measures can be both quantitative and qualitative.

This example illustrates how it is possible to densify cities at the cost of a certain amount of green public space, provided that the individual assessment concludes that there is proximity to suitable green areas nearby. For this to happen, an assessment needs to be done in order to consider the use of green space in a way that accords with both the Planning and Building Act and the Environmental Code. More importantly, this example also illustrates how the 'green space factor', and related policies contained in the outline of the local plan, are increasing the importance of commencing an investigation to agree on suitable measures to compensate for the corresponding reduction of the park.

\section{Example 3 - Örebro's digital municipal plan and nature reserves within urban areas}

The third Swedish example illustrates the use of legislation in a municipality's comprehensive plan and its focus on nature in proximity to urban areas. Örebro municipality is relatively well-known in Sweden for the establishment of nature reserves within, or close to, urban areas (see, for example, Naturvårdsverket, 2019d). Figure 2 shows the existing nature reserves (top map), and the intended land use for green structures, green areas and nature by 2040 (lower map), according to the municipality's comprehensive plan (see more in Örebro municipality, 2018). As mentioned above, nature reserves can be established by the municipality or by the County Administrative Board. Nature reserves close to or within urban areas in Örebro have all been established by the municipality, illustrating its proactive work in preserving nature and creating accessible recreational areas for the local population.

The digital municipal plan is also a useful tool with which to indicate, in a visible way, the general structures of land use pertaining to the municipality's comprehensive plan, which must be carried out in accordance with the country's Planning and Building Act. By adding layers to the map, the user can easily read and find out about specific areas, and what is being planned for their future. Users can also access chapters about those general layers (for example protected areas, nature, or green structures) in the written version of the municipal plan. In this way, the municipality has outlined its 

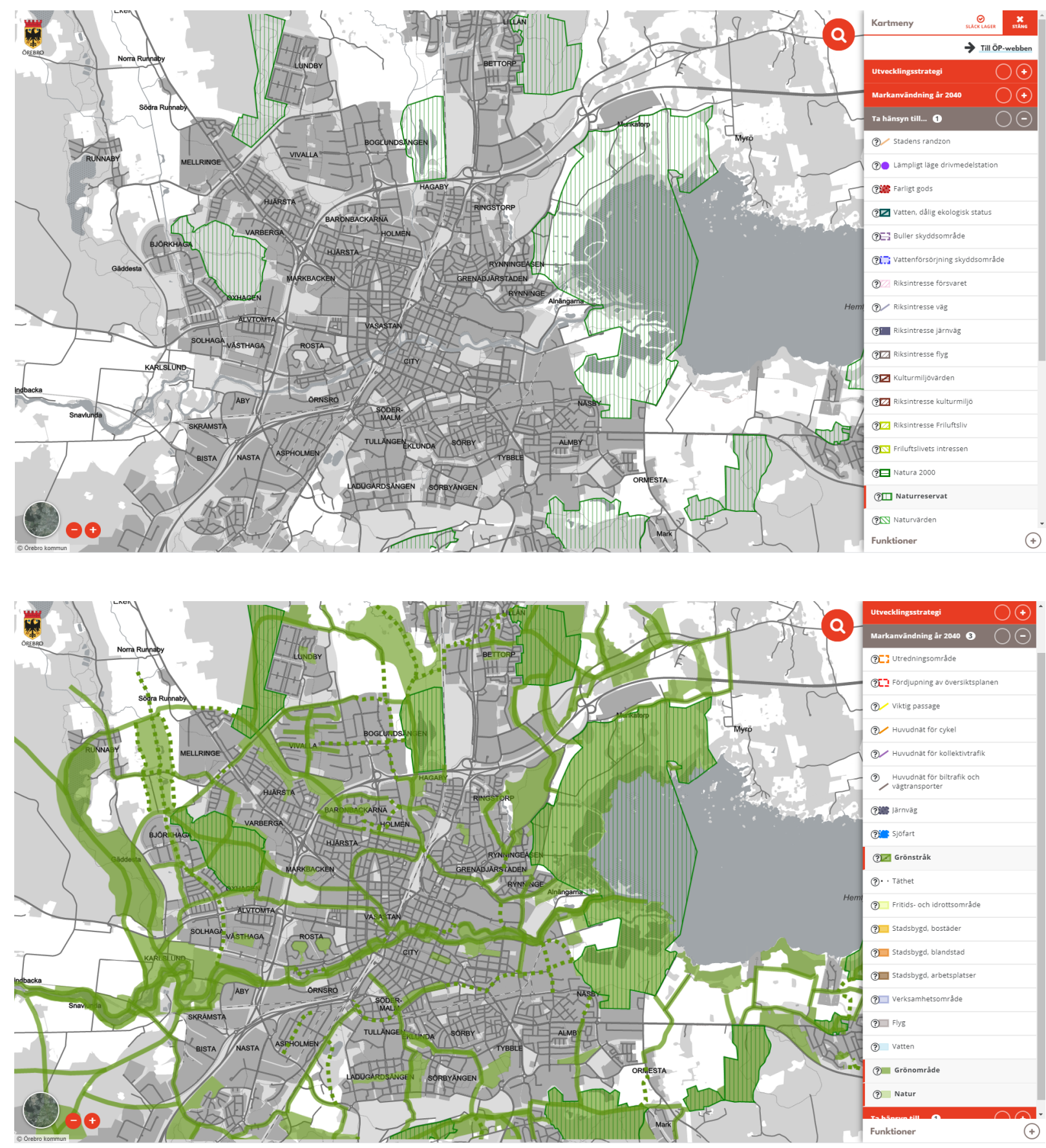

Figure 2: Both maps are from the digital-online map of Örebro municipality's comprehensive plan. The top map illustrates the existing nature reserves within or in proximity to Örebro's urban settlement - all are municipal nature reserves. The lower map illustrates the land use of 2040 when it comes to green structure, green areas and nature. Source: Örebro municipality 2018.

view and standpoint regarding land use, for example, in relation to protected areas and nature. This example illustrates two things. First that the general structure of land use and the municipal perspective on this have been effectively and transparently outlined in the municipality's comprehensive plan. Second, that there has also been much proactive work carried out by the municipality, which has taken the initiative in establishing nature reserves within urban areas. The new digital municipal plan makes it pretty easy for a user to navigate and access information about current and future land use, not least in relation to the example of green urban areas. 


\section{Analysis and conclusions}

The overview presented in the previous chapter and the sub-chapters for each of the five Nordic countries illustrates the importance of the planning systems involved in each, including planning legislation and related laws regarding the regulation of land use in terms of supporting urban green space. Table 1, below, summarises the legal framework, focussing on planning laws and related environmental legislation. This table is best understood by reading it in association with the text presented in each country's sub-chapter.

What has become clear from this study is that all Nordic countries use spatial planning, or at least have the possibility of using spatial planning, to study, enable and regulate what we might call 'green qualities' (and green structures) in urban areas. The available planning instruments differ from country to country and have varied implications. One general observation that can be made is that national planning instruments seem to have less actual impact on urban green areas across all the Nordic countries, in contrast to the more local planning instruments. Having said that, this does not mean that the national planning instruments are less important. In fact, they are steering planning discourse and practice as a whole in a particular direction.

For example, in Iceland, all plans are required to be in line with the National Planning Strategy. The municipal plan is, moreover, approved by the National Planning Agency - but even so, how municipalities develop, and how they conduct and implement their local plans is up to them. In Denmark, national planning directives are regulative, and therefore legally binding. One clear example is the Copenhagen Finger plan, which involves regulation to stop the conversion of green wedges into urban zones. The trend in Denmark is still to minimise the involvement of national actors in spatial planning. National expectations in Norway constitute another set of national planning instruments, which in their latest version have placed significant emphasis on the importance of green urban spaces
- both in terms of the all-important stormwater management and for creating good environments to live in. Since national expectations need to be considered in regional and municipal planning strategies, which in turn are influential for the specifics of regional and municipal plans, the national planning instrument may, in fact, influence local planning instruments in Norway much more than is evident at a surface level.

Related to this, all Nordic countries can be seen to possess similarities in their legislation regarding national and regional goals. All municipal planning must outline how it has considered such goals in various ways. However, it is often up to each individual planning authority and planning project to make the relevant assessment in each case. This means that, in practice, the consideration of relevant goals for 'urban greening' might be applied totally differently across different municipalities in the same country. The way this is applied in planning practice is not studied in this report, but what can be concluded from what we have seen is that national goals and policies will, in various ways, be considered in municipal plans - both comprehensive and detailed - and that they can prove influential.

Another similarity within the legal framework across the Nordic countries is that spatial planning, on a general level, pays particular attention to nature and to green areas. The wording of the legislation may differ between countries. For example, in Sweden, all planning must consider that within, or in proximity to, areas where cohesive building plans exist, there must be green provision - for example, parks or other green areas. In Finland, this is expressed similarly. Local detailed plans must ensure that there are sufficient parks or other green areas suitable for local recreation in the zone covered by the plan, or in its vicinity. In Denmark, the Planning Act is intended to ensure that the overall planning framework unites the interests of society with respect to land use, and also helps protect the country's natural environment. 
Table 1: Planning and Environmental legislation regarding urban green values and urban greenery in the Nordic Countries

Planning legislation

\begin{tabular}{|c|c|c|c|c|c|}
\hline & DK & FI & IS & NO* & SE \\
\hline $\begin{array}{l}\text { Planning instru- } \\
\text { ments that can be } \\
\text { used to regulate } \\
\text { green values in } \\
\text { urban areas }\end{array}$ & $\begin{array}{l}\text { Municipal, } \\
\text { detailed plan and } \\
\text { national planning } \\
\text { directives. } \\
\text { National planning } \\
\text { reports are } \\
\text { also important } \\
\text { instruments for } \\
\text { guiding planning } \\
\text { policy. }\end{array}$ & $\begin{array}{l}\text { Regional, } \\
\text { municipal and } \\
\text { local detailed } \\
\text { plans. }\end{array}$ & $\begin{array}{l}\text { Regional, } \\
\text { municipal and } \\
\text { detailed plans. }\end{array}$ & $\begin{array}{l}\text { (Regional), } \\
\text { municipal and } \\
\text { detailed plans }\end{array}$ & $\begin{array}{l}\text { Regional, } \\
\text { municipal and } \\
\text { detailed plans. }\end{array}$ \\
\hline $\begin{array}{l}\text { What are the } \\
\text { main regulative } \\
\text { differences } \\
\text { between planning } \\
\text { levels? }\end{array}$ & $\begin{array}{l}\text { Municipal, } \\
\text { detailed plan and } \\
\text { national planning } \\
\text { directives are all } \\
\text { legally binding. }\end{array}$ & $\begin{array}{l}\text { All are legally } \\
\text { binding. }\end{array}$ & $\begin{array}{l}\text { All planning levels } \\
\text { are legally bind- } \\
\text { ing. A regional } \\
\text { plan overrules a } \\
\text { municipal plan, } \\
\text { which in turn } \\
\text { overrules a de- } \\
\text { tailed plan. }\end{array}$ & $\begin{array}{l}\text { Legally bind- } \\
\text { ing on all three } \\
\text { levels, but for } \\
\text { urban green } \\
\text { space municipal } \\
\text { and detailed } \\
\text { plans are most } \\
\text { influential. }\end{array}$ & $\begin{array}{l}\text { Only the de- } \\
\text { tailed plan is } \\
\text { legally binding. } \\
\text { The others are } \\
\text { advisory. }\end{array}$ \\
\hline $\begin{array}{l}\text { At which planning } \\
\text { level are urban } \\
\text { greenspaces } \\
\text { mainly regulated? }\end{array}$ & $\begin{array}{l}\text { Municipal plans } \\
\text { and detailed } \\
\text { plans. The na- } \\
\text { tional planning } \\
\text { directive for the } \\
\text { Greater Copen- } \\
\text { hagen Area. }\end{array}$ & $\begin{array}{l}\text { Mainly in region- } \\
\text { al and detailed } \\
\text { plans. It may } \\
\text { occur in munici- } \\
\text { pal plans. }\end{array}$ & $\begin{array}{l}\text { Mainly in } \\
\text { municipal and } \\
\text { detailed plans. } \\
\text { For the Greater } \\
\text { Reykjavik area, a } \\
\text { regional plan for } \\
\text { the capital area } \\
\text { municipalities. }\end{array}$ & $\begin{array}{l}\text { Mainly in munic- } \\
\text { ipal and detailed } \\
\text { plans. }\end{array}$ & $\begin{array}{l}\text { Mainly in the } \\
\text { detailed plan. }\end{array}$ \\
\hline $\begin{array}{l}\text { How is greenspace } \\
\text { regulated? (e.g. } \\
\text { as public space, } \\
\text { through own } \\
\text { zoning objectives, } \\
\text { etc.) }\end{array}$ & $\begin{array}{l}\text { Mainly as public } \\
\text { space in detailed } \\
\text { plans. In the } \\
\text { national planning } \\
\text { directive for Co- } \\
\text { penhagen, some } \\
\text { green areas are } \\
\text { defined based on } \\
\text { transport needs. } \\
\text { These 'green } \\
\text { wedges' must be } \\
\text { maintained as } \\
\text { such for recre- } \\
\text { ational purposes }\end{array}$ & $\begin{array}{l}\text { Special zones } \\
\text { and markings for } \\
\text { the use of land } \\
\text { in regional, mu- } \\
\text { nicipal and local } \\
\text { detailed plans. }\end{array}$ & $\begin{array}{l}\text { Mainly as public } \\
\text { space. The term } \\
\text { 'green space' } \\
\text { is used quite } \\
\text { freely in Icelan- } \\
\text { dic regulation } \\
\text { and policy. It can } \\
\text { apply to city and } \\
\text { neighbourhood } \\
\text { parks, islands } \\
\text { within urban } \\
\text { limits, coastal } \\
\text { areas, organised } \\
\text { outdoor areas, } \\
\text { recreational and } \\
\text { sports-related } \\
\text { areas, cycling } \\
\text { and hiking trails, } \\
\text { riding paths, pro- } \\
\text { tected and water } \\
\text { conservation } \\
\text { areas, etc. }\end{array}$ & $\begin{array}{l}\text { Mainly as a land- } \\
\text { use objective } \\
\text { called 'green } \\
\text { structure', } \\
\text { and as a zone } \\
\text { requiring special } \\
\text { consideration. }\end{array}$ & $\begin{array}{l}\text { By indicating } \\
\text { green struc- } \\
\text { tures as part } \\
\text { of the general } \\
\text { structure of } \\
\text { land and water } \\
\text { areas in the } \\
\text { municipal plan. } \\
\text { Mainly as public } \\
\text { space (allmänn } \\
\text { platsmark) in } \\
\text { the detailed } \\
\text { plan. There are } \\
\text { few and limited } \\
\text { possibilities in } \\
\text { a detailed plan } \\
\text { to regulate } \\
\text { urban greenery } \\
\text { in develop- } \\
\text { ment districts } \\
\text { (kvartersmark). }\end{array}$ \\
\hline
\end{tabular}




\begin{tabular}{|c|c|c|c|c|c|}
\hline $\begin{array}{l}\text { Mandatory or } \\
\text { voluntary } \\
\text { regulations } \\
\text { (e.g. must, shall } \\
\text { or may) }\end{array}$ & $\begin{array}{l}\text { Mainly voluntary. } \\
\text { Through the } \\
\text { national planning } \\
\text { directive. (E.g. } \\
\text { the Copenha- } \\
\text { gen Finger Plan } \\
\text { puts limits and } \\
\text { obligations on } \\
\text { the relevant } \\
\text { municipal plans). } \\
\text { The planning } \\
\text { act includes an } \\
\text { obligation for } \\
\text { municipalities } \\
\text { to formulate } \\
\text { guidelines for the } \\
\text { administration } \\
\text { of nature areas } \\
\text { and ecological } \\
\text { corridors. }\end{array}$ & $\begin{array}{l}\text { Voluntary, but } \\
\text { all plans must } \\
\text { be based on suf- } \\
\text { ficient, demon- } \\
\text { strable back- } \\
\text { ground studies. }\end{array}$ & $\begin{array}{l}\text { Voluntary on all } \\
\text { three planning } \\
\text { levels, but } \\
\text { mandatory } \\
\text { regional plan for } \\
\text { the capital area. } \\
\text { But they must } \\
\text { be in line with } \\
\text { national policy. } \\
\text { Municipal plans } \\
\text { are, however, } \\
\text { approved by the } \\
\text { NPA. }\end{array}$ & $\begin{array}{l}\text { Voluntary but } \\
\text { 'green structure' } \\
\text { has been, since } \\
2008 \text {, land-use } \\
\text { objective. }\end{array}$ & $\begin{array}{l}\text { Mainly voluntary } \\
\text { on all three } \\
\text { planning levels, } \\
\text { but all planning } \\
\text { decisions must } \\
\text { consider prox- } \\
\text { imity to green } \\
\text { areas. }\end{array}$ \\
\hline $\begin{array}{l}\text { Other important } \\
\text { regulations in } \\
\text { the planning } \\
\text { legislation }\end{array}$ & $\begin{array}{l}\text { The Nature } \\
\text { Protection Act, } \\
\text { the Building Act, } \\
\text { the Forestry Act, } \\
\text { the National } \\
\text { Park Act, the } \\
\text { Land Distribu- } \\
\text { tion Act and EU } \\
\text { environmental } \\
\text { directives. }\end{array}$ & $\begin{array}{l}\text { National Urban } \\
\text { Parks and } \\
\text { stormwater } \\
\text { management. } \\
\text { In the detailed } \\
\text { plan, there } \\
\text { should be suffi- } \\
\text { cient parks and } \\
\text { other areas for } \\
\text { local recreation. }\end{array}$ & $\begin{array}{l}\text { Planning of } \\
\text { Marine and } \\
\text { Coastal Area } \\
\text { Act, Act on } \\
\text { Environmental } \\
\text { Impact } \\
\text { Assessment, } \\
\text { Act on the } \\
\text { Environmental } \\
\text { Assessment } \\
\text { of Plans, } \\
\text { Environment } \\
\text { and Natural } \\
\text { Resources } \\
\text { Appeals } \\
\text { Committee Act. }\end{array}$ & $\begin{array}{l}\text { Shoreline } \\
\text { protection; } \\
\text { that planning } \\
\text { programmes } \\
\text { should be } \\
\text { prepared if } \\
\text { plans on any or } \\
\text { all levels may } \\
\text { have significant } \\
\text { impacts on the } \\
\text { environment and } \\
\text { society. }\end{array}$ & $\begin{array}{l}\text { Each planning } \\
\text { project must } \\
\text { assess that it } \\
\text { within, or in } \\
\text { close proximity } \\
\text { to, areas } \\
\text { of cohesive } \\
\text { buildings exist } \\
\text { e.g. parks or } \\
\text { other green } \\
\text { areas. }\end{array}$ \\
\hline \multicolumn{6}{|c|}{ Environmental legislation } \\
\hline & DK & FI & IS & NO* & SE \\
\hline $\begin{array}{l}\text { Briefly, how are } \\
\text { green values } \\
\text { in urban areas } \\
\text { considered in the } \\
\text { environmental } \\
\text { legislation (e.g. } \\
\text { protected areas) }\end{array}$ & $\begin{array}{l}\text { The Act aims to } \\
\text { protect nature, } \\
\text { species, and } \\
\text { habitats, as } \\
\text { well as cultural } \\
\text { values, while } \\
\text { ensuring good } \\
\text { public access to } \\
\text { nature. }\end{array}$ & $\begin{array}{l}\text { Regulations and } \\
\text { provisions } \\
\text { concerning the } \\
\text { protection of } \\
\text { nature reserves, } \\
\text { natural monu- } \\
\text { ments, } \\
\text { special biotopes, } \\
\text { landscapes and } \\
\text { species - which } \\
\text { should be } \\
\text { followed similarly } \\
\text { in urban areas. }\end{array}$ & $\begin{array}{l}\text { Environmental } \\
\text { Act aims to } \\
\text { protect the } \\
\text { diversity of } \\
\text { Icelandic nature, } \\
\text { including biolog- } \\
\text { ical, geological } \\
\text { and landscape } \\
\text { diversity, as } \\
\text { well as ensuring } \\
\text { the constant } \\
\text { development } \\
\text { of nature on its } \\
\text { own terms, and } \\
\text { the protection of } \\
\text { what is special or } \\
\text { of historical value } \\
\text { there. }\end{array}$ & $\begin{array}{l}\text { Protected areas } \\
\text { such as nature } \\
\text { reserves and } \\
\text { national parks, } \\
\text { not limited to a } \\
\text { geographically } \\
\text { defined } \\
\text { territory. }\end{array}$ & $\begin{array}{l}\text { National } \\
\text { interests are set } \\
\text { out; these which } \\
\text { could have } \\
\text { implications for } \\
\text { green values. } \\
\text { Protected areas } \\
\text { such as nature } \\
\text { reserves and } \\
\text { national parks. } \\
\text { Shoreline } \\
\text { protection. }\end{array}$ \\
\hline
\end{tabular}




\begin{tabular}{|c|c|c|c|}
\hline $\begin{array}{l}\text { Other important } \\
\text { regulations in the } \\
\text { environmental } \\
\text { legislation }\end{array}$ & $\begin{array}{l}\text { The Act includes } \\
\text { regulations } \\
\text { regarding the } \\
\text { protection of } \\
\text { certain habitat } \\
\text { types and } \\
\text { permitting } \\
\text { processes for } \\
\text { structural } \\
\text { developments in } \\
\text { the landscape. }\end{array}$ & $\begin{array}{l}\text { Municipalities, } \\
\text { with approval } \\
\text { of the EPA, are } \\
\text { permitted to } \\
\text { preserve land for } \\
\text { outdoor } \\
\text { recreation and } \\
\text { public use as a } \\
\text { national park. } \\
\text { The protection } \\
\text { of the area shall } \\
\text { be aimed at } \\
\text { facilitating public } \\
\text { access to nature } \\
\text { in close proximity } \\
\text { to urban areas. }\end{array}$ & $\begin{array}{l}\text { The need for } \\
\text { green areas in } \\
\text { urban settle- } \\
\text { ments or in } \\
\text { proximate to } \\
\text { urban settle- } \\
\text { ments shall } \\
\text { particularly } \\
\text { be considered } \\
\text { regarding land- } \\
\text { use interests }\end{array}$ \\
\hline
\end{tabular}

*In Norway the Outdoor Recreation Act, the Public Health Act and the Cultural Heritage Act are also important, complementary pieces of legislation for regulating urban green space.

The language of the legislation, which specifies that all spatial planning must consider nature and/or green areas in various ways, could in some respects be understood as being rather vague. Spatial planning, in all Nordic countries, involves compromising with various land-use interests, as well as with the public, national and individual interests. For instance, in the second Swedish example, we can see how a detailed plan considered the need for green space within a densification project and concluded that the need could still be satisfied. This meant, in effect, that other interests were prioritised and green space was considered only on a general level in making that assessment.

In the Nordic countries, urban green space is mainly regulated in municipal and detailed plans, even though Finland's legally binding regional plans are used to pinpoint the general structures of land use, and what are known as 'green structures'. In Iceland, regional plans are made on a voluntary basis when municipalities cooperate together, exept for the capital region were a regional plan is mandatory and in the capital region, the legally binding regional plan has been quite successful in terms of regulating green structures at a regional level. Compared to the other Nordic countries, only in Sweden is the most local plan the only legally binding one. Despite that, a Swedish municipality's comprehensive plan must outline the general structure of all land and water areas involved, which in turn becomes advisory for the legally binding detailed plans that follow.

On the municipal level, general structures or zones of land use are outlined in varying degrees across all the Nordic countries. In most of these countries, urban green areas are regulated as public space, or as unspecified land in 'development districts', or similar. In Sweden, for example, there are limited options to regulate green space in designated development districts. These are becoming more important for the development of 'ecosystem services' when (green) public spaces in cities are being densified. Norway is the Nordic country which can be distinguished the most from the other countries in the region. In Norway, urban green space has been regulated since 2008 as an 'own land use' objective, or as a zone requiring special consideration - in other words, it is acknowledged as its own object and legal concept. This land-use objective is applied both in municipal and detailed plans. In Norwegian planning practice, it means that green structures are to be considered in the initial phases of the planning process, particularly since they are defined as adhering to their own legal concept. However, it has been beyond the scope of this study to examine in detail the implications of this legal concept for planning practice.

Yet in all Nordic countries, it remains voluntary to regulate green values in urban areas, with some important exceptions. In Denmark, the natural environment needs to be considered in all planning, and the Finger Plan puts a limit on the capacity of municipal plans in the Greater Copenhagen area to convert 'green wedges' into urban areas. Also, the Danish Planning Act includes an obligation for municipalities to formulate guidelines for the administration of nature areas (areas of particular natural value) and ecological corridors. In Finland, all plans for the use of land must be based on suffi- 
cient background studies. Equally, all local detailed plans must make sure that there are sufficient parks nearby. In Iceland, all three plans voluntarily regulate the urban green space, but the final shape of this must be in line with the National Planning Strategy, and municipal plans must also be approved by the National Planning Agency. In Norway, the legal concept of 'green structure', as well as complementary legislation such as the Outdoor Recreation Act and Public Health Act, acknowledge access to green spaces as important features of land use and development. In Sweden, regulating green space is voluntary, but since all planning must consider proximity to green areas in urban settings, it is invariably a consideration in practice.

Another rather distinctive and successful regulation regime for urban green space is the $\mathrm{Na}$ tional Urban Parks scheme in Finland. The framework here is quite similar to the one in Sweden - but there is one particular, crucial difference. In Finland, there are nine national urban parks, but there is only one in Sweden. Also, in Finland there is an eagerness among many cities to establish a national urban park, and therefore to preserve green areas and their connected networks. That is not possible in Sweden, because only one national urban park is defined in the legislation. Another motivation for establishing the national urban parks in Finland is to strengthen each city's attractiveness as a green, viable place. In a comparative Nordic perspective, the Finnish approach could potentially be scaled up and used to facilitate wider learning across the region. Finally, there are important environmental laws in the Nordic countries which regulate protected areas. In general, they are not limited to any specific geographic territory, unless otherwise specified. Also, a general shoreline protection is common in most Nordic countries, in order to protect green-blue areas from urban development (see more in each country chapter).

\section{Strengths and weaknesses}

Based on this, we can see that there are obviously both strengths and weaknesses in all the legal frameworks adopted across the Nordic countries. This has already been outlined, to some degree, above. Strengths and weaknesses are also dependent upon the purpose and objectives underlying each framework - whether there is the need for stronger national involvement, or whether it would be sufficient to strengthen the existing le- gal framework. Also, the Finnish case involving $\mathrm{Na}-$ tional Urban Parks, which have created incentives for some municipalities to strive to establish one of their own, is but one way of approaching this. In general terms, there are a few practical strengths and weaknesses to be outlined.

In Denmark, the main advantage and opportunity in the spatial planning system is the fact that much development is commonly done at national and municipal levels, while more authority is now being moved towards the local level, promoting public participation and access to information. In this way, greater local acceptance can be gained for complex, multi-layered planning decisions. Securing participation, however, is always a challenge, as is improving the practical understanding of spatial planning. This is because it crosses over between different policy sectors and projects, such as those involving nature, water, climate and recreational projects. But ultimately it must still rest upon national interests and policies.

While in the updated Planning Act, regulations and obligations are placed on municipalities to plan for the protection of nature, and especially to secure continuous green areas that cross municipal borders, less emphasis is put on those green areas which are closer to the core of dense urban areas. The existing legislation focuses more on the outskirts, on the green wedges and corridors, and this is quite often defined by transport needs.

The Copenhagen Finger plan can also be viewed as a strength since it creates green areas across municipal borders and concentrates the development of buildings in proximity to public transit hubs and transportation corridors, rather than pursuing development on preserved green areas.

In Iceland, the possibility exists for the National Planning Agency to steer development through an advisory National Planning Strategy, but then also to help municipalities by assisting, reviewing and approving all plans throughout Iceland. This coherent approach could be viewed as a strength. Another strength would be that the legislation involved allows for voluntary regional plans, which in the case of the capital area have been quite successful in terms of preserving, protecting and developing green urban areas.

A potential weakness, however, is that there are no formal requirements to designate green urban areas. It is up to each municipality to make that assessment itself. But it must still consider 
the National Planning Strategy and relevant national goals, which at the moment are focused on green issues among others.

Another strength can be identified in Finland, in the example of its legally binding regional plans. If used for the right purpose, these can enable and regulate general green connectivity on a larger geographical scale. Also, the National Urban Parks programme has created a willingness among some municipalities to work voluntarily towards establishing one for themselves. This is evidently a strength.

The establishment of 'green structure' as a legal concept in Norway could be considered a strength, too, because green structures are now acknowledged and included in early phases of the various planning processes. However, there is no guarantee as to how the six land-use objectives will be designated for the planning area - that is, how to draw borders in relation to these zones? The complementary legislation that exists in Norway could also be considered a strength, in terms of acknowledging many different perspectives on urban green space.

In Sweden, one strength would be the possibility of working with green structures in municipal plans and in programmes that are advisory for the more detailed plans. On the other hand, the fact that they are advisory means that there is a risk that they will not be fully implemented within the detailed plans. Equally, the fact that both the planning legislation and the environmental legislation acknowledges the importance of assessing the need for green areas, and that this shall particularly be considered in relation to urban areas, could certainly be viewed as a strength. But it also opens up the process so that each planning project is left to make that assessment for itself. There is also a risk that green spaces in urban areas only are considered in the detailed plans, which therefore lack an overall municipal perspective on green infrastructure corridors and connectivity. However, that is very much dependent on the local planning authority, the municipal council and/or local policy documents.

\section{Further efforts and policy recommendations}

Based on the findings from our study, we may conclude there is a need for further effort in the following areas:

It would be good to gain a better understanding of the actual practice of the legislation, from a comparative Nordic perspective.

- This would require a study involving more practical examples examined in-depth, including interviews and/or workshops with spatial planners, environmental planners, policy-makers at different levels of government. These could furnish useful methods to explore further the use of the legislation in this field.

- Studying more local policies in relation to developing, preserving and protecting green values in urban areas would also be useful in helping to identify new, innovative policy tools and recommendations.

- Investigating the potential use of the 'green space factor', or similar, to be integrated within planning legislation - either as a voluntary or a mandatory tool. What would the effects of such a tool be?

- National authorities could continue to take the initiative in finding the most appropriate solution, in their national context, as to how tools such as these should be integrated within the current legal framework.

- Create incentives at national level which might encourage municipalities to proceed in a certain direction when it comes to developing, preserving and protecting green urban areas (for example, being inspired by the National Urban Parks model in Finland). 


\section{European Outlooks}

\section{The Netherlands}

The Dutch planning system is mainly framed by a new law on spatial planning called Wet ruimtelijke ordening (Wro). A new Environment Act (Wet algemene bepaling Omgevingswet, or Wabo) is under development and is expected to become active in 2021. This will be of importance to the urban green space debate in the near future.

There are a few responsible ministries of relevance to all this. Policies for urban areas fall under the responsibility of the Ministry of Internal Affairs (BZK, Minister Kajsa Ollongren). Policies for nature are under the Ministry of Agriculture, Nature and Food (LNV, Minister Carola Schouten) and for the environment, under the Ministry of Infrastructure and Water (I\&W, Minister Cora van Nieuwenhuizen). Also, climate policies relating to green space in urban areas are under the responsibility of the Ministry of Economic Affairs (EZ, Minister Eric Wiebes).

\section{Legis/ation}

The new law on spatial planning: Wet ruimtelijke ordening (Wro)

The new law on spatial planning (Wet ruimtelijke ordening, or Wro, generated in 2008) is important for spatial decision-making in the Netherlands, drawing attention to the quality and importance of urban green spaces in enabling these decisions. This legislation helpfully distinguishes between policy and standard-setting. In relation to policy, the law requires that each municipality should develop a Structural Vision, in which the spatial development horizon is described, and strengthened with an implementation strategy. In terms of standard-setting, municipalities are obliged to develop local land-use plans, integration plans, or (for areas with a limited number of developments) management plans. Local land-use plans dictate the kind of use permissible, and the rules or prescriptions for use, which decision-makers need to respect.

In addition, the provinces and the state - the two other government levels in the Netherlands, of which the state is the highest - are obliged to develop structural visions for their respective geographical areas. These are not binding. Structural visions are points of reference for the response of citizens, businesses, NGOs and other authorities, and need to be accounted for in that context. Only provincial regulations or spatial Royal Decrees (algemene maatregelen van bestuur) are binding, and these must be followed in local land-use plans (omgevingsweb.nl). Tellingly, there are no such decrees focussing on the quality, quantity or use of green space in urban areas.

"The municipal council can, for aspects of municipal spatial policy, define a structural vision", the Wro notes. Nature may be one such an aspect, but it is not mandatory to consider the natural environment as such. However, it is not uncommon for municipalities to develop a structural vision pertaining to nature or to green space development specifically. Structural vision is important for land exploitation. It enables the parties involved to spread local planning costs over several other projects. This is because financial agreements regarding the exploitation of land can be based on the structural vision. So the absence of such a vision particularly effects land exploitation (www.infomil.nl).

What this means is that land-use and planning legislation does not guarantee the development, preservation and protection of green qualities in urban areas in quantitative terms. This legislation leaves the development, preservation and protection of the green qualities of urban areas to the sole discretion of the respective authorities. "The state avoids taking the place of provinces and municipalities". So the National Structure, Vision, Infrastructure and Space report notes in 2012. This means that, in effect, it leaves the management of green qualities and features in urban areas to the discretion of provinces and local municipalities. In qualitative terms, land-use planning is decisive for the utilisation of green areas, because land-use plans can specify details about the quality of green space that needs to be guaranteed - for example, the monument status of an alley, or the conservation status of a wildlife area. So green spaces (areas covered by green land) can be part of local land-use plans. In that case, they will generally appear as public spaces, as undefined parts of a private green in residential areas, or as verges along 
waterways or roads. Designations of use such as 'nature' or 'wildlife areas' are generally confined to peri-urban or rural areas. Also, the spatial planning legislation known as the Wabo (Wet algemene bepalingen Omgevingswet, see below) and the Tracéwet (on major transport infrastructure) applies to these judgements too (www.omgevingsweb.nl). It should be noted that the Netherlands is presently in a situation of transition between this legislation (Wro) and the new approach set out by environmental law (see the following section).

\section{Relevant environmental legislation in the Netherlands}

A change of legislation is currently underway; one which focuses more on the environment. In general terms, this implies a wider scope for municipal planning, including not only spatial planning but also, and most importantly, environmental planning. The Environment Act (Wet algemene bepaling Omgevingswet, or Wabo) is presently under development and is expected to become active in 2021. It aims to combine various laws (for example those concerned with spatial planning, infrastructure, water, residence, environment, nature, agriculture, archaeology and monuments). These had become altogether too voluminous, unwieldy and complex to deal with, many have felt. As a result, municipalities had to bundle and reformulate local land-use plans, management regulations (see above) and other rules pertaining to the physical living environment from these various laws, pulling them into one coherent Environment Plan. For developments such as construction or road development, builders have to request an Environmental Permit from the municipality. The Environment Plan is considered a more comprehensive local landuse plan, including all aspects of the physical environment, including green areas. It specifies those activities which require an Environment Permit.

Underlying the Environment Plan is the Environment Vision, which municipalities are obliged to develop. This sets out the main objectives in terms of developing the outdoor environment. It needs to be a comprehensive plan, not simply the sum of several separate structural visions (www.vng.nl). Two-thirds of Dutch municipalities have already written an Environment Vision, and $10 \%$ of these visions have already taken effect.

\section{Influential Dutch national policies}

Relevant and important guidelines or policies in this area include the Urban Agenda (Agenda Stad) and the compact city policy. Recently, nature conservation organisations have launched the Deltaplan Biodiversity, which has now been presented to parliament.

In the Agenda Stad cities, NGOs and the state cooperate to promote 'growth, liveability, and innovation'. Green space is only one of the issues embraced within this agenda. The Agenda Stad works with City Deals, involving both public and private partners. It is an action-oriented agenda which comprises measures to strengthen growth, enhance quality of life, and promote innovation in Dutch cities. It was agreed by the Council of Ministers on 14 November 2014.

The compact city policy aims to preserve green spaces outside urban areas and leads directly to intensification or densification policies inside those urban areas. These generally proceed at the expense of existing urban green space. Then there is the Climate Law, which sets the target for the reduction of $\mathrm{CO} 2$ emissions and for climate adaptation policies, including the 2016 National Adaptation Strategy (Ministerie van Infrastructuur en Milieu, 2016). This strategy has recently taken into the built environment. The Deltaplan Spatial Adaptation (Ruimtelijke adaptatie) should also be mentioned. This plan has been established by municipalities, water boards, provinces and the state. It aims to make the Netherlands more resilient in relation to climate change.

\section{Implementation and practical examples Example 1 - TEEB stad.}

As part of the Agenda Stad, the City Deal 'TEEB 4 stad' was developed. It wanted to look more clearsightedly at the potential of green space ideas. This particular City Deal was signed by some seven Dutch cities, together with companies and government ministries responsible for health, infrastructure, environment and economic affairs. The deal expired in June 2019. The city of The Hague used the TEEB stad-tool to calculate that the total number of houses in the city were together worth 1.9 billion euro more than they would have been in a situation where there were no trees, parks or lawns. The city of Apeldoorn used the TEEB-

\footnotetext{
4 TEEB $=$ The Economics of Ecology and Biodiversity.
} 
Stad-tool to improve an urban park that was old, derelict and controlled by youngsters who were simply hanging around. This tool was used to pinpoint the added value of potential changes under consideration. It indicated the possibility of substantial returns on investment. This buttressed a process by which different parties could now see how their particular interests might be served by participating in the project. Private companies, the Land Registry and the municipality forged cooperative links in the context of the City Deal. The park has now been upgraded and functions as a virtual business card for the city (agendastad.nl/ groen-geld-waard). The Deal also spurred work on a Natural Capital Atlas. (www.agendastad.nl) There are a few other City Deals that look at green space-related issues now, including the issue of the city-wide climate resilience.

\section{Example 2 - Environment Vision City of Utrecht,} and urban green space in Lunetten district

The new legislation on the environment (see previous section) has led to the development of Environment Visions in many Dutch cities. An Environment Vision points itself towards the horizon, focussing on thematic objectives - for example, an urban green, or parking - and then examines possible practical variations for specific geographical areas. "The living environment is the public space in which we live, work, meet and recreate. It comprises districts and neighbourhoods, but also the shopping centre and the park", the municipality of Utrecht writes in its Environment Vision. "In this Environment Vision, you will read what we want to improve, but also what we want to conserve or protect". The vision has been adopted by the City Council and has been in operation since June 2017.

Lunetten is a specific area for which the City of Utrecht has developed an area-oriented add-on to its Environment Vision. Lunetten is an experimental district which developed in the 1970s, with the participation of residents in guiding designers. Residents (mostly highly educated ones) took part in the design process at all levels. The scale ran from urban planning through to landscaping and the design of individual buildings and courtyards. Popular participation is still powerful, and the district's qualities are considered stronger than those of comparable urban districts which had also grown up in the 1970s (www.aorta.nu). A participatory

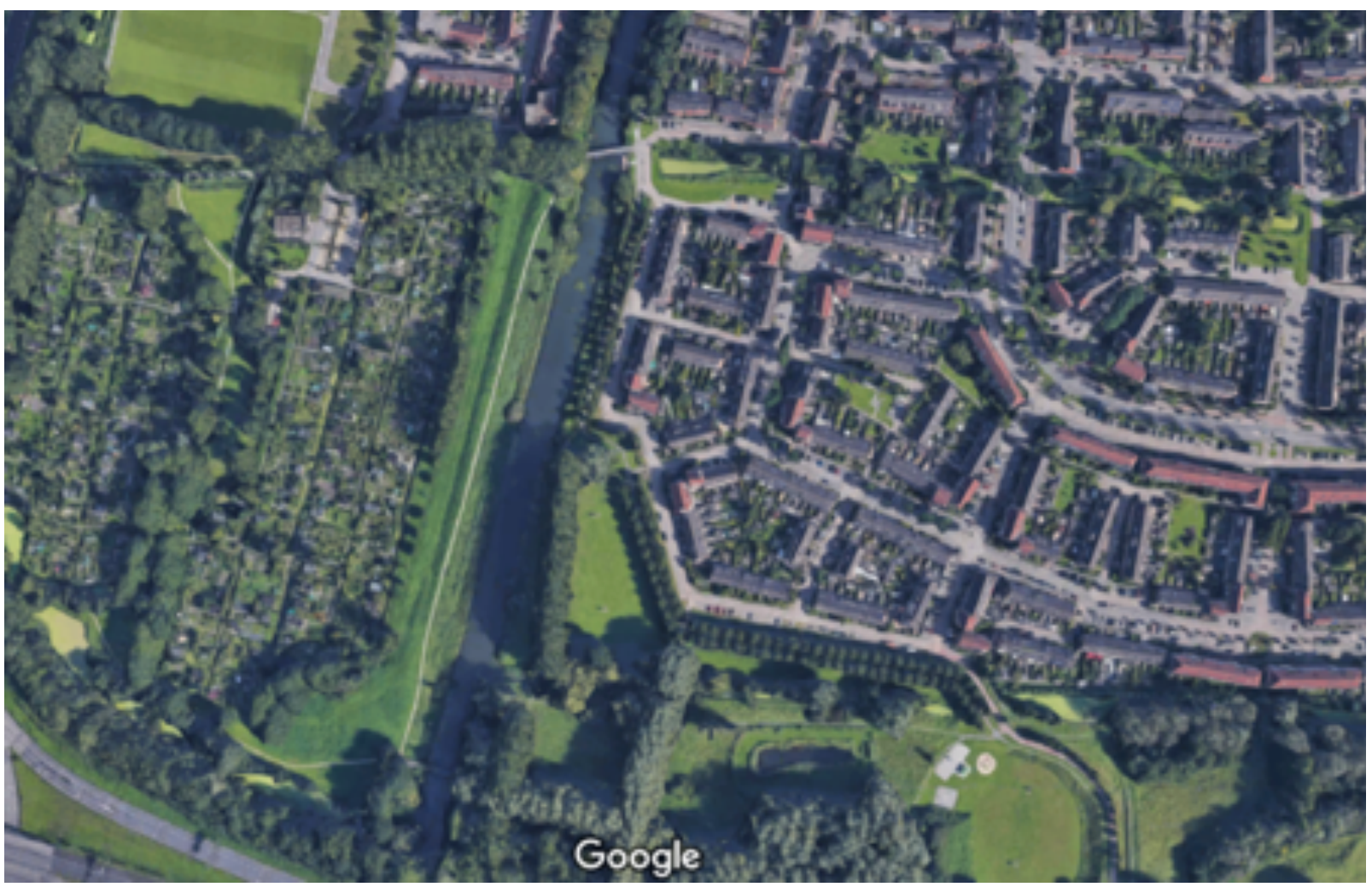

Figure 3. A section from Lunetten district, showing boundaries on the left and at the foot, various green functions, and residential areas with numerous green courtyards. Source: Google Maps. 
approach involving the city (in effect the municipality), other partners and residents, and interested parties from the district was implemented by agreeing locally on what was of most value in the development of the area, and how to procure or strengthen such things. This resulted in the following formulated ambitions in relation to urban green space: "The people of Lunetten want to live in Lunetten park. Lunetten wants to set an example as a sustainable area. A lively atmosphere, connections and encounters are central issues for Lunetten." Each ambition has been developed into a specific proposal for practical realisation. These proposals can be implemented by residents, or by other initiators and partners. Some depend on coordination and facilitation by the city authority.

The draft Environment Vision for Lunetten was opened up to formal public consultation this spring (2019). As the City of Utrecht is reconsidering its spatial strategy for the whole city, it is also looking at creating extra buildings around the railway station at Lunetten. This would upgrade the area as a central node within the wider public transport system. It would also link the surrounding areas, creating a gateway to green spaces all around the district. Elsewhere in Lunetten, there is little scope for generating the profits needed to pay for the development costs involved, so the city hopes to make up for this in other areas within Utrecht; that is, to spread these specific costs over other projects.

\section{Germany}

The German planning system is characterised by the so-called 'mutual feedback principle' (Gegenstromprinzip). This principle is based upon mutual 'adaption' downwards, and mutual 'consideration' upwards. As such, it facilitates the vertical interplay of different policy levels with regard to spatial planning and particularly land-use planning. Figure 4 below illustrates the different policy levels, the main formal planning instruments, and how coordination with other sectoral policy fields (such as environmental planning and water management) takes place.

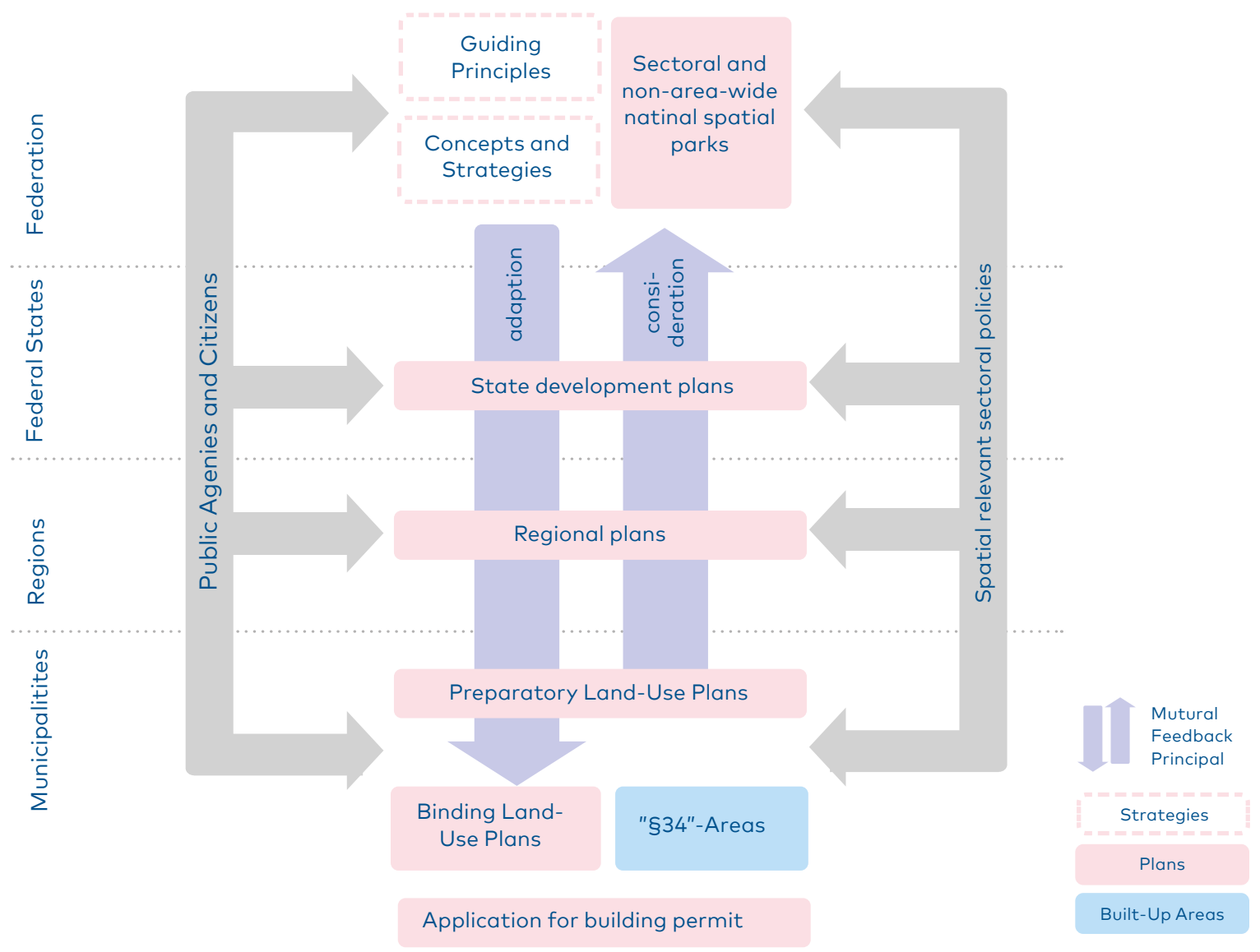

Figure 4: The German spatial planning system. Source: Münter and Reimer (2017, page 12), based on BBSR (2012). 


\section{Legis/ation}

Main characteristics and legal instruments of German land-use and planning legislation in relation to urban green areas

Federal spatial planning takes effect not so much through concrete plans, but rather by providing organisational and material guidelines for such planning. On the basis of the widely-recognised mutual-feedback principle, national guidelines can have a positive effect in helping to develop, preserve and protect green qualities and facilities in urban areas. In particular, the Spatial Planning Act (Raumordnungsgesetz) sets out practical guidance (Leitvorstellungen) for sustainable spatial development and stipulates the principles (Grundsätze) involved in planning that is concerned with the organisation of space, the development of a settlement structure, and the creation of appropriate infrastructure for the tasks involved (Blotevogel et al, 2014). This act comes under auspices of the Federal Spatial Planning Authority, which at the moment is integrated into the Federal Ministry of Transport and Digital Infrastructure (Bundesministerium für Verkehr und digitale Infrastruktur).

The federal states (Länder) need to substantiate these principles, both sectorally and spatially, as part of their state spatial development plans (Landesentwicklungspläne), but also legally in terms of state planning laws (Landesplanungsgesetze). The federal reforms of 2006 re-arranged the way competences for spatial planning (in legal terms) were divided between the federation and the federal states. This has given the federal states more freedom to enact laws which diverge from the Federal Spatial Planning Act. Nonetheless, even before this reform, considerable variations existed (and still do) with regard both to the legal frameworks involved and to the application of land-use planning in the 16 federal states. Regional planning involves respecting the specifications of Federal State development plans for smaller trans-municipal areas on the one hand, and providing a framework for land-use planning, spatial development and sectoral planning in the municipalities on the other (Scholl et al, 2007). The exceptions are the so-called 'city states' (Stadtstaaten), such as Hamburg and Berlin.

Land-use planning at municipal level is regulated nationwide by the Federal Building Code (Baugesetzbuch), which presently sits under auspices of the Federal Ministry of the Interior, Building and Community (Bundesministerium des Innern, für Bau und Heimat), and which has a two-tier structure. The preparatory land-use plan (Flächennutzungsplan) covers the entire territory of the municipality and is only binding for public authorities. Detailed land-use plans (Bebauungspläne) are generally binding for smaller parts of the municipal territory. In relation to urban green areas, the Federal Building Code stipulates that a preparatory land-use plan "[....] shall [author's emphasis] represent in basic form the type of land uses arising for the entire municipal territory, in accordance with the intended urban development - something proposed to correspond with the anticipated needs of the municipality. [...] Land-use plans shall [author's emphasis] safeguard sustainable urban development and a socially equitable utilisation of land for the general good of the community, and shall contribute to securing a more human environment and to protecting and developing the basic conditions for natural life. [...] The preparatory landuse plan may show [author's emphasis] in particular [...] green spaces, such as parks, allotment gardens, sports grounds, playgrounds, campsites and bathing areas, cemeteries; [...]".

Further, the Federal Building Code specifies that the detailed land-use plan "may [author's emphasis] [...] make designations regarding [...] the type and degree of building and land-use; [...] spaces for common facilities and for sports and play areas; [...] spaces to be kept free from built development, with their use; [...] public and private green spaces, such as parks, allotment gardens, sports grounds and playgrounds, camping sites and bathing areas, cemeteries; [...] spaces for community amenities to serve specific spatial areas, such as children's playgrounds, leisure facilities [...] planting of trees, shrubs and greenery of any other kind,[...] obligations relating to planting and to the preservation of trees, shrubs and greenery of any other kind and of water bodies $[\ldots]^{\prime \prime}$.

Main characteristics and legal instruments of the German environmental legislation in relation to urban green areas

The Federal Nature Conservation Act (Bundesnaturschutzgesetz), which is presently under the auspices of the Federal Ministry of Environment, Nature Conservation, Building and Nuclear Safety (Bundesministerium für Umwelt, Naturschutz und Reaktorsicherheit) plays an important role in relation to urban green areas. The so-called impact regulation rule (Eingriffsregelung), which under- 
pins this act, stipulates that negative impacts from measures (such as infrastructures, larger buildings) for the environment are to be avoided or to be reduced. In case this is not possible, this rule prescribes the realisation of measures for providing compensation for such negative consequences. Regarding the latter, the related instrument is an accompanying landscape conservation plan (landschaftspflegerischer Begleitplan), which is supposed to support the planning of compensation measures. In addition, the Federal Nature Conservation Act is related to the Federal Building Code, and as such ensures that environmental concerns are integrated into formal planning processes. One section of the Federal Nature Conservation Act is specifically concerned with 'Landscape Planning'. In relation to (urban) green spaces it is stipulated that "[...] regional requirements and measures which serve the interests of the conservation of nature and of landscapes shall [author's emphasis] be laid down for all areas and Federal States, in the form of landscape programmes where the entire territory of a Federal State is involved, and in the form of landscape master plans where specific areas of land are concerned. In the process, the objectives of spatial planning shall [author's emphasis] be respected; the principles and other requirements of spatial planning shall [author's emphasis] be taken into account. [...] Local requirements and measures promoting the cause of nature and landscape conservation shall [author's emphasis] be specified by means of text, maps and additional justification, where this is required for reasons of nature and landscape conservation. [...]". These plans shall for instance, specify areas for the maintenance and development of open spaces in both populated and non-populated areas.

These legal requirements are further specified at the Federal State level. For instance, the Federal State Nature Conservation Act (Landesnaturschutzgesetz) in North-Rhine Westphalia (Nordrhein-Westfalen), the biggest Federal State in Germany by population with almost 18 million inhabitants, is supposed to specify more precisely that the above-mentioned regional requirements shall be laid down in a landscape programme (Landschaftsprogramm) for the territory of the entire Federal State, as well as in regional plans, which as such function as landscape master plans (Landschaftsrahmenpläne). However, contrary to most of the other Federal States, the former, a landscape programme, has not been developed so far. The Federal State Nature Conservation Act of North-Rhine Westphalia further specifies that local requirements shall be laid down in the municipal landscape plan (Landschaftsplan). Besides stipulating a particular number of local requirements and objectives, these plans shall also lay down measures for developing, preserving and protecting natural or green areas, as well as promoting biodiversity. However, such plans normally apply for those areas within the municipal jurisdictions which are not covered by detailed land-use plans. As such, municipal landscape plans have a complementary function but a rather limited effect on developing, preserving and protecting urban greens, since urban areas are generally covered by detailed land-use plans.

\section{The importance of maintenance for quality urban greenspace}

Municipal green space in Germany is characterised by a variety of land types. Examples are greenery and parks (including town squares), urban housing estates and small parks, but also bathing lakes, playgrounds, street greens including protective greenery, and so on.

The quality of these surface types, and the quality of public greens, depends upon the interplay of project planning with (1) the overall planning, (2) the construction, and (3) the maintenance of green areas. There are various laws which oblige owners to design, plan, build and maintain the greens in their possession (for example, municipal regulations, the federal building law, state building regulations, the federal nature conservation law, and copyright law). All owners of green areas (the public sector, private organisations and private persons) are obliged by private law to keep green areas and trees safe. This includes the obligation to check and, if necessary to maintain, urban green areas. In other words, it requires at least a minimum level of care.

The quality of the public greens in Germany depends upon the project organisation, planning, construction and maintenance of particular green areas. The project planning, spatial planning and construction of green spaces are paid for by investment funds and EU subsidies. There are also a number of laws at federal level which promote public green spaces. Maintenance of urban green space is a mandatory task of the owner, and also a responsibility of the municipality. But many municipalities lack sufficient budgets for the main- 
tenance of green spaces, resulting in a relatively bad quality of urban greenery all over the country - despite outstanding examples from, for example, Freiburg, Munich, and so on. The importance of management in maintaining an urban green space properly should not be underestimated, and it is seen as an important challenge in Germany.

\section{Examples of local and regional strategies, instruments and practices}

Returning back to the Federal State of NorthRhine Westphalia, one can easily point to a number of innovative approaches in the development, preservation or protection of green qualities in cities. Specifically, in the formerly heavily industrialised Ruhr region (Ruhrgebiet), cities like Dortmund, Essen or Duisburg were characterized by larger, and for the most part contaminated, industrial areas (steelworks, coking plants and so on) that were often centrally located and which have since been enveloped by a rather disorganised settlement structure. Many of these former industrial areas have been gradually turned into publicly accessible open green spaces. For this purpose, a number of formal and informal planning instruments have been developed. One example is the International Building Exhibition Emscherpark (Internationale Bauaustellung Emscherpark), which ran in the 1990s and focused on the northern part of the Ruhr region (Schmitt and Rickegård, 2015). The name of the exhibition is rather misleading, since most of the funding, which basically came from the Federal State of North-Rhine Westphalia, and partly from the EU, has been used to advance the ecological modernisation of this region. One of its flagship projects has been rehabilitating the highly polluted river Emscher, which once served as what was essentially an industrial sewage channel. It has now been developed into a floating, clean river once more. The huge investment programme involved in carrying out this project, which was set in motion some years ago, and which is still not complete, has been accompanied by developing and connecting urban green zones at a larger scale in order to create the so-called Emscher Landscape Park. This park is supposed

Figure 5: Part of the rehabilitated Emscher and the PHOENIX lake in 2014. Picture by Peter Schmitt.

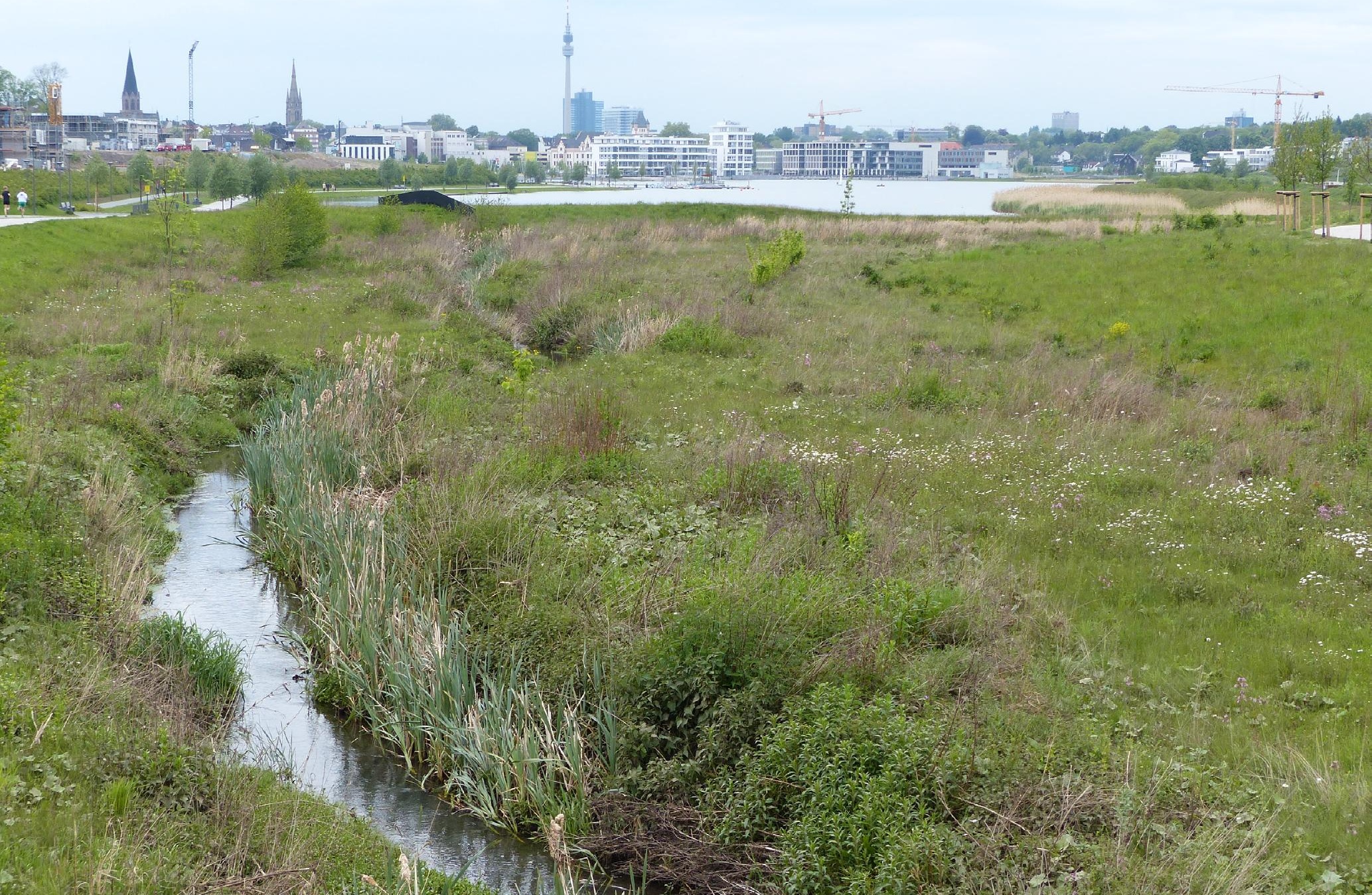




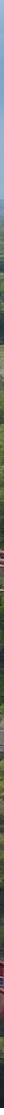

Figure 6: The Zeche Zollverein coal mining plant, and the adjacent cooking plant, surrounded by the industrial wood (Industriewald) in 2014. Picture by Peter Schmitt.

to stretch over an area of more than 60 kilometres from the East to the West of the northern part of the Ruhr region. It shall cover an area of 350 square kilometres. The Emscher Landscape Park follows up on, and is linked to, earlier regional planning measures that have been applied since the 1920s. In this case, the most relevant one is the project to develop seven north-south green wedges through the Ruhr region. In order to further spur the planning work on this, in 2010 the Master Plan Emscher Landscape Park was 'adopted', which is an informal planning instrument to coordinate the measures of 20 municipalities in the Ruhr region. Besides these examples of planning for urban green areas at the regional level, a number of approaches and instruments may be found at the local level.

With regard to the planning practices of the city of Dortmund, for instance, the so-called integrated urban development concepts (integrierte Stadtentwicklungskonzepte) play a central role in the generation of urban green spaces. These have been developed at a district level since the early 2000s. This informal planning instrument is closely aligned both to binding, preparatory land-use plans, and to concerned, detailed land-use plans, in order to give them a certain authority to devel- op, among other things, urban green spaces at the neighbourhood scale. Another important informal planning instrument in Dortmund is the urban green plan (Stadtgrünplan) for the entire municipal territory. Its aim is to assess the provision of, and further need for, urban green spaces. As such, it is applied to advocate decisions on investments in terms of preservation and development, for instance. One lighthouse project in Dortmund can be found at the PHOENIX location in the district Hörde, which was the site of a huge steelworks and a coking plant until 1998 . Since then the 200 -hectare area has been developed into two distinct zones: a technology park in the west, which is partially equipped with a number of cultural and leisure facilities; and a lake in the eastern part, which is surrounded by high-class housing and open spaces for a variety of recreational activities. Both parts of the area are home to 22 monuments from the industrial age. However, urban green plays a superior role in both areas, namely for developing new houses (with 35 hectares available) and with another 26 hectares devoted to green areas, plus the lake which covers a further 25 hectares. The lake is embedded in what is called "the new Emscher valley" (neves Emschertal, see figure 5), As such, it is part of the above-mentioned large-scale 


\section{References}

\section{General references}

CEC, (1997). The EU Compendium of Spatial Planning Systems and Policies. Regional Development Studies. Luxemburg: Commission of the European Communities.

ESPON COMPASS, (2018). Comparative Analysis of Territorial Governance and Spatial Planning Systems in Europe, https://www.espon.eu/ planning-systems

Nadin V., and Stead D. (2008). European Spatial Planning Systems, Social Models and Learning. dis $P$-The Planning Review, 44, 35-47. doi.org/10. 1080/02513625.2008.10557001

Slätmo, E., Ormstrup Vestergård, L., Lidmo, J., and Turunen, E. (2019). Urban-rural flows from seasonal tourism and second homes: Planning challenges and strategies in the Nordics. Nordregio Report 2019:13. Stockholm: Nordregio.

Smas, L. and Lidmo, J. (2018). Organising regions: spatial planning and territorial governance practices in two Swedish regions. Europa XXI 35, 21-36. doi.org/10.7163/Eu21.2018.35.2

Stjernberg, M., and Penje, O. (2019). Population change dynamics in Nordic municipalities - grid data as a tool for studying residential change at local level. Edition 2. Nordregio Report 2019:1. Stockholm: Nordregio.

Strandell, A., and Hall, C. M. (2015). Impact of the residential environment on second home use in Finland - Testing the compensation hypothesis. Landscape and Urban Planning, 133, 12-23. // doi.org/10.1016/j.landurbplan.2014.09.011

Tunström, M. Lidmo, J. and Bogason, Á. (2018). The compact city of the north - functions, challenges and planning strategies. Nordregio Report 2018:4. Stockholm: Nordregio.

Qviström, M., Bengtsson, J., and Vicenzotti, V. (2016). Part-time amenity migrants: Revealing the importance of second homes for senior residents in a transit-oriented development. Land Use Policy, 56, 169-178. doi.org/10.1016/j. landusepol.2016.05.001

\section{Case References \\ Denmark}

Bydesign i Køpenhavns. Erfaringar fra Sluseholmen. The Port and City Development Corporation, (2007). Urban development - in Ørestad and in the harbour areas of Copenhagen.

Convention on the Rights of Persons with Disabilities, retrieved 2019-10-17. https:// www.un.org/development/desa/disabilities/ convention-on-the-rights-of-persons-withdisabilities/convention-on-the-rights-ofpersons-with-disabilities-2.html

Danish Business Authority (2018), retrieved 201910-15, http://kort.plandata.dk/spatialmap

The Danish Government (2016). DENMARK'S NATIONAL REFORM PROGRAMME 2016, Ministry of Finance, Denmark, The Danish Government (2015).

The Danish Nature Agency (2012). SPATIAL PLANNING IN DENMARK, Ministry of the Environment, Denmark.

Galland, D. (2012). Understanding the Reorientations and Roles of Spatial Planning: The Case of National Planning Policy in Denmark. European Planning Studies, 20(8), 1359-1392. https://doi.org/10.1080/09654313.2 012.680584

Galland, Daniel and Stig Enemark (2013). Impact of Structural Reforms on Planning Systems and Policies: Loss of Spatial Consciousness?, Refereed article No. 52, September 2013, European Journal of Spatial Development.

Hansen, J. R. (2015). APRILab: Regulation Dilemma in South Harbor and Aalborg East, Denmark. University of Amsterdam, Amsterdam Institute of Social Science Research.

Hansen, J. R., and Engberg, L. A. (2017). Sydhavn, Copenhagen: Why different types of selforganization have varying adaptive qualities. In F. Savini, and W. Salet (Eds.), Planning Projects in Transition: Interventions, Regulations and Investments (Chapter 6, pp. 114-139). Berlin: Jovis Verlag.

Lov om miljøvurdering af planer og programmer og af konkrete projekter (VVM), retrieved 
2019-10-14 - https://www.retsinformation.dk/ Forms/R0710.aspx?id=203447

Lov om nationalparker, retrieved 2019-10-14 - https://www.retsinformation.dk/Forms/ R0710. aspx?id=186417

Lov om skover, retrieved 2019-10-14- https:// www.retsinformation.dk/Forms/R0710. aspx?id=186419

Lov om vandplanlægning , retrieved 2019-1014.- https://www.retsinformation.dk/Forms/ R0710.aspx?id=186425

Lov om vandløb, retrieved 2019-10-13. - https:// www.retsinformation.dk/Forms/R0710. aspx?id=186438

Lov om miljøvurdering af planer og programmer og af konkrete projekter, retrieved 2019-1013. - https://www.retsinformation.dk/Forms/ R0710.aspx?id=203447

Miljostyrelsen 2017, Vejledning om Grønt Danmarkskort - , retrieved 2019-10-13. http:// mst.dk/media/133265/groentdanmarkort_ vejledning.pdf

Ministry of Environment and food of Denmark (2018), retrieved 2019-10-13. http://miljoegis. mim.dk/cbkort?profile=miljoegis - plangroendk

Olesen, K., and Richardson, T. (2012). Strategic Planning in Transition: Contested Rationalities and Spatial Logics in Twenty-First Century Danish Planning Experiments. European Planning Studies, 20(10), 1689-1706. https:// doi.org/10.1080/09654313.2012.713333

Planloven, retrieved 2019-10-11. https:// www.retsinformation.dk/forms/R0710. aspx?id $=200614$

Roskilde Kommun, Roskilde Kommunplan, 2016, , retrieved 2019-10-13.- https:// kommuneplan2016.roskilde.dk/

Tepecik Diș, A., Smas, L., Dymén, C., Fredricsson, C., Larsson, V., Perjo, L., ... Weber, R. (2014). Green growth and spatial planning in the Nordic city regions: An overview of concepts and policies (Nordregio Working Paper No. 2014:5) (p. 71). Stockholm: Nordregio. Retrieved from http://www.nordregio.se/en/ Publications/Publications-2014/Green-growthand-spatial-planning-in-theNordic-cityregions/

Vejle Kommune, Kommuneplan, 2017-2029 for Vejle Kommune og Trekantområdet, 2017 http://kommuneplan2017.vejle.dk/download/ samlet_kommuneplan_2017-2029_med_ rettelsesblad.pdf
Vækst og udvikling i hele Danmark, Erhvervs- og Vækstminsterie, Danmark.

\section{Finland}

Biodiversity Action Plan Finland (2019), retrieved 2019-09-13, https://www.luonnontila.fi/ toimintaohjelma/toimenpiteet/elinymparistotluonnonvarat/rakennetut-ymparistot/ kaupunkiluonnon-monimuotoisuus

Finlex 1996:1096, Nature Protection Act (in Finnish), retrieved 2019-09-13, https://www. finlex.fi/fi/laki/ajantasa/1996/19961096

Finlex 1996:1096, Nature Protection Act (in English), retrieved 2019-09-13, https://www. finlex.fi/en/laki/kaannokset/1996/en19961096. pdf

Finlex 1999:132, Land Use and Planning Act (in Finnish), retrieved 2019-09-09, https://www. finlex.fi/fi/laki/ajantasa/1999/19990132

Finlex 1999:132, Land Use and Planning Act (in English), retrieved 2019-09-09, https://www. finlex.fi/fi/laki/kaannokset/1999/en19990132. pdf

Finlex 1999:895, Land use and building decree (in Finnish), retrieved 2019-09-11, https://www. finlex.fi/fi/laki/ajantasa/1999/19990895

Finlex 2001/119, Water Service Act (in Finnish), retrieved 2019-09-11, https://www.finlex.fi/fi/ laki/ajantasa/2001/20010119

Finlex 2014:527, Environmental Protection Act (in Finnish) retrieved 2019-09-09, https://www. finlex.fi/fi/laki/smur/2014/20140713

Finnish Council of the Finnish State (2017), Valtakunnalliset alueidenkäytöntavoitteet (National land use goals by the Council of State), retrieved 2019-09-09, http://www.ymparisto.fi/download/ noname/\%7B67CD97B8-C4EE-4509-BECOAF93F8D87AF7\%7D/133346

Helsinki, (2018), Helsingin kaupungin hulevesiohjelma, Strom water management plan, retrieved 2019-09-19, https://www.hel.fi/ static/liitteet/kaupunkiymparisto/julkaisut/ julkaisut/julkaisu-03-18.pdf

Interreg EU, (2018), retrieved 2019-09-19 http:// www.integratedstormwater.eu/

Jyväskylä (2012), Jyväskylän ekologinen viherverkko, Selvitys yleiskaavaa varten, retrieved 2019-10-08, http://www2.jkl.fi/ kaavakartat/jkl_yleiskaava/jkl_ekologinen_ viherverkko.pdf 
Ministry of Environment (2014) Arviointi maankäyttö- ja rakennuslain toimivuudesta 2013, (Impact assesment of Land Use and Building Act 2013) https://www.ym.fi/ download/noname/\%7BD444BEBO-F0154808-9C27-C61391811E02\%7D/98032

Ministry of Environment (2019), retrieved 201909-09, https://mrluudistus.fi/sv/

Ministry of the Environment (2015), Ilmastotavoitteita edistävä kaavoitus - Näkökulmia kuntakaavoitukseen, retrieved 2019-10-08, https://tem.fi/ documents/1410877/2735615/Ilmastotavo itteita+edist\%C3\%A4v\%C3\%A4+kaavoitu $\mathrm{s}+\mathrm{N} \% \mathrm{C} 3 \% \mathrm{~A} 4 \mathrm{k} \% \mathrm{C} 3 \% \mathrm{~B} 6 \mathrm{kulmia}+\mathrm{kuntakaav}$ oitukseen.pdf/27465bOe-8af8-4bb8-95ab158f7557ad39/IImastotavoitteita+edist\%C3\% A4v\%C3\%A4+kaavoitus+N\%C3\%A4k\%C3\%B6 kulmia+kuntakaavoitukseen.pdf.pdf

Regional Council of Häme (2016), Kanta-Hämeen Ekoliginen verkosto (Regional assessment of the ecological network), retrieved 2019-09-13, https://www.hameenliitto.fi/sites/default/ files/hameen_ekologisten_verkostojen_ selvitys_luonnos_10.10.2016.pdf

Oulu, (2014) Oulun viheralueverkosto ja luonnon monimuotoisuus suunnitelma, Green network and biodiversity plan in Oulu, retrieved 201909-13 https://www.ouka.fi/c/document_ library/get_file?uvid=6df84cfb-d91c-46ab$90 b 8-675$ e24baf1cb\&groupld $=64220$ I

\section{Iceland}

Act on protection in urban areas - Lög um verndarsvæði í byggð, retrieved 2019-10-19 https://www.althingi.is/lagas/149c/2015087. html

Act on environmental impact of assessments Lög um umhverfismat áætlana nr. 105/2006, retrieved 2019-10-19 - https://www.althingi.is/ lagas/nuna/2006105.html

Act on marine planning and costal areas - Lög um skipulag haf- og strandsvæða105/2006, retrieved 2019-10-20 - https://www.althingi.is/ lagas/149c/2015087.html

Act Nature Preservation - Lög um náttúruvernd 2013 nr. 60105/2006, retrieved 2019-10-20 https://www.althingi.is/lagas/nuna/2013060. html

Action Plan For the Disabled, 2017105/2006, retrieved 2019-10-19 - https://www.althingi.is/ altext/146/s/1000.html
Framkvæmdaáætlun í málefnum fatlaðs fólks, 2017105/2006, retrieved 2019-10-19 - https:// www.althingi.is/altext/146/s/1000.html

National Planning Ágency (2016). National Planning Strategy 2015-2026 - https:// www.landsskipulag.is/media/pdf-skjol/ Landsskipulagsstefna2015-2026_asamt_ greinargerd.pdf

Nature Preservation Act105/2006, retrieved 2019-10-19 - https://www.althingi.is/lagas/ nuna/2013060.html

Mennta og menningarmálaráðuneyti (2014). Menningarstenfa í mannvirkjagerð - Stefna íslenskra stjórnvalda í byggingarlist - https:// www.fsr.is/utgefid-efni/stefnur-stjornvalda/

Riki Thérivel, Pietro Caratti, Maria do Rosário Partidärio, Ásdís HlökkTheodórsdóttir and David Tyldesley (2004). Writing strategic environmental assessment guidance,Impact Assessment and Project Appraisal, 22:4, 259270, DOI: 10.3152/147154604781765824

Reykjavík municipal plan 2010-2030 (2013) (Reykjavík aðalskipulag 2010-2030) 105/2006, retrieved 2019-11-09 - https://reykjavik.is/ thjonusta/adalskipulag-reykjavikur

Reykjavík municipal plan 2010-2030, English version (2014). retrieved 2019-11-09 https://reykjavik.is/sites/default/files/skjol_ thjonustulysingar/20140922_ar_a5_en_bleed. pdf

Skipulagslög - Laws on Planning, retrieved 2019-10-12 - https://www.althingi.is/lagas/ nuna/2010123.html

Skipulagsstofnun, 2019, retrieved 2019-10-09 http://www.skipulag.is/skipulagsstofnun/umskipulagsstofnun/

Theodórsdóttir, Á. H., Leiðbeiningar um gerð aðalskipulags - ferli og aðferðir (Guidance on municipal plan-making - process and methods), National Planning Agency, 2003.

The Capital Area Development Plan 2040 (Höfuðborgarsvæðið 2040) - https://www.ssh. is/images/stories/Hofudborgarsvaedid_2040/ HB2040-2015-07-01-WEB_Undirritad.pdf

Umhverfis- og auðlindaráðuneytið Verkefnisstjórn aðgerðaáætlunar í loftslagsmálum, Aðgerðaáætlun í loftslagsmálum2018 - 2030, September 2018, retrieved 2019-10-19 - https:// www.stjornarradid.is/lisalib/getfile. aspx?itemid=b1bda08c-b4f6-11e8-942c$005056 \mathrm{bc} 4 \mathrm{~d} 74$ 
Umhverfisstofnun (2019). Retrieved 2019-10-13 https://www.ust.is/umhverfisstofnun/log-ogreglur/log/

\section{Norway}

Act on nature areas in Oslo and nearby municipalities (LOV-2009-06-05-35), retrieved 2019-11-04, https://lovdata.no/dokument/NL/ lov/2009-06-05-35

Kommunal- og moderniseringsdepartementet (2011). Statlige planretningslinjer for differensiert forvaltning av strandsonen langs sjøen, retrieved 2019-11-18, https://www. regjeringen.no/no/dokumenter/differensiertforvaltning-strandsonen/id636763/

Kommunal- og moderniseringsdepartementet (2014). Statlige planretningslinjer for samordnet bolig-, areal-og transportplanlegging, retrieved 2019-11-18, https://www.regjeringen.no/no/dokumenter/ Statlige-planretningslinjer-for-samordnetbolig--areal--og-transportplanlegging/ id2001539/

Kommunal- og moderniseringsdepartementet (2016). Byrom - En idehåndbok: Hvordan utvikle byromsnettverk i byer og tettsteder, retrieved 2019-11-18, https:// www.regjeringen.no/contentassets/ c6fc38d76d374e77ae5b1d8dcdbbd92a/byrom_ idehandbok.pdf

Kommunal- og moderniseringsdepartementet (2018). Statlige planretningslinjer for klima- og energiplanlegging og klimatilpasning, retrieved 2019-11-18, https://lovdata.no/dokument/SF/ forskrift/2018-09-28-1469

Kommunal- og moderniseringsdepartementet (2019a). National expectations regarding regional and municipal planning 2019-2023, retrieved 2019-09-27, https://www.regjeringen. no/no/tema/plan-bygg-og-eiendom/plan--ogbygningsloven/plan/statlige-planoppgaver/ statlige-planretningslinjer-spr/id664274/

Kommunal- og moderniseringsdepartementet (2019b). Statlige planretningslinjer (SPR), retrieved 2019-11-18, https://www.regjeringen. no/no/tema/plan-bygg-og-eiendom/plan--ogbygningsloven/plan/statlige-planoppgaver/ statlige-planretningslinjer-spr/id664274/

Miljødirektoratet (2014). Planlegging av grønnstruktur i byer og tettsteder. Veileder, Retrieved 2019-10-03, https://www. miljodirektoratet.no/publikasjoner/2014/ oktober-2014/planlegging-av-gronnstruktur-ibyer-og-tettsteder/

Miljødirektoratet (2019). Tilstand. Mye landareal vernet, lite sjø, retrieved 2019-11-11, https:// miljostatus.miljodirektoratet.no/tema/ naturomrader-pa-land/vernet-natur/

Miljødirektoratet (n.d.). Norges miljømål, retrieved 2019-11-11, https://miljostatus. miljodirektoratet.no/miljomal/

Riksantikvaren (n.d). Grøntanlegg, retrieved 2019-11-17, https://www.riksantikvaren.no/ Ansvarsomraader/Groentanlegg

The Cultural Heritage Act (LOV-1978-06-0950), retrieved 2019-11-17, https://lovdata.no/ dokument/NL/lov/1978-06-09-50

The Nature Diversity Act (LOV-2009-06-19100), retrieved 2019-11-18, https://lovdata.no/ dokument/NL/lov/2009-06-19-100

The Outdoor Recreation Act (LOV-1957-06-2816), retrieved 2019-11-18, https://lovdata.no/ dokument/NL/lov/1957-06-28-16

The Planning and Building Act (LOV-2008-06-2771), retrieved 2019-11-18, https://lovdata.no/ dokument/NL/lov/2008-06-27-71

The Public Health Act (LOV-2011-06-24-29), retrieved 2019-11-18, https://lovdata.no/ dokument/NL/lov/2011-06-24-29

Voss kommune (2015). Kommuneplanen 2015 2026. Arealdelen, retrieved 2019-11-18, https:// www.voss.kommune.no/_f/p1/i6a178a70-d7884f12-b819-500e9ff18073/arealdel.pdf

Voss kommune (2018). PLANPROGRAM. Ny Sentrumsplan Vossevangen, retrieved 2019-11-18, http://webhotel3.gisline. no/GisLinePlanarkiv/1235/2018001/ Dokumenter/6a\%20Vedtatt\%20 planprogram\%2002.08.18\%20VK.pdf

Voss kommune (2019a). Plankart, retrieved 2019-11-18, http://webhotel3.gisline. no/GisLinePlanarkiv/1235/2018001/ Dokumenter/1a\%2OPlankart-15.08.19\%2OVK. pdf

Voss kommune (2019b). Planomtale. Områdeplan for Vossevangen 2020-2040, retrieved 2019-11-18, http://webhotel3. gisline.no/GisLinePlanarkiv/1235/2018001/ Dokumenter/1c\%2OPlanomtale\%20 $-15.08 .19 \% 20 V K . p d f$ 


\section{Sweden}

Boverket (2011). Sammanställning av nationella mål, planer och program av betydelse för fysisk samhällsplanering. Rapport 2011, 7. Karlskrona: Boverket, retrieved 2019-11-19, https://www. boverket.se/globalassets/publikationer/ dokument/2011/sammanstallning-mal-planer. pdf

Boverket (2018a). Ekosystemtjänster och PBL:s verktyg, retrieved 2019-09-26, https://www. boverket.se/sv/PBL-kunskapsbanken/Allmantom-PBL/teman/ekosystemtjanster/pbl/ verktyg_PBL/

Boverket (2018b). Egenskapsbestämmelser för allmän plats, retrieved 2019-11-19, https:// www.boverket.se/sv/PBL-kunskapsbanken/ planering/detaljplan/planbestammelser/ egenskapsbestammelser/

Boverket (2018c). Mål för ekosystemtjänster retrieved 2019-09-26, https://www.boverket. se/sv/PBL-kunskapsbanken/Allmant-om-PBL/ teman/ekosystemtjanster/det_har/mal/

Boverket (2019). Promemoria om genomförande av regeringsuppdrag och behov av fortsatta insatser för att nå etappmål för stadsgrönska och ekosystemtjänster i urbana miljöer.

Diarienummer3175/2018

ESPON GRETA (2019). GRETA - Green infrastructure: Enhancing biodiversity and ecosystem services for territorial development, https://www.espon.eu/green-infrastructure

Malmö stad (2017). Grönytefaktor, retrieved 2019-11-19, https://malmo.se/Sa-arbetar-vimed.../Malmo-stads-miljoarbete/Hallbarstadsutveckling/Miljobyggstrategi-forMalmo/Information-och-goda-exempel/ Ekosystemtjanster-och-gronytefaktorn/ Gronytefaktor.html

Malmö stad (2018). Dp 5559, fastigheten Teknikern 2, retrieved 2019-09-11, Dp 5559, fastigheten Teknikern 2

Naturvårdsverket (2018). Friluftsmålet attraktiv tätortsnära natur, retrieved 2019-09-26, http://www.naturvardsverket.se/Miljoarbetei-samhallet/Miljoarbete-i-Sverige/Uppdelatefter-omrade/Friluftsliv/Friluftsmalen/ Attraktiv-tatortsnara-natur/
Naturvårdsverket (2019a). Att ta fram handlingsplaner för grön infrastruktur, retrieved 2019-09-26, https://www. naturvardsverket.se/Stod-i-miljoarbetet/ Vagledningar/Samhallsplanering/Groninfrastruktur/

Naturvårdsverket (2019b). The generational goal, retrieved 2019-09-26, http://www.swedishepa. se/Environmental-objectives-and-cooperation/ Swedens-environmental-objectives/Thegenerational-goal/

Naturvårdsverket (2019c). Milestone targets, retrieved 2019-09-26, http://www.swedishepa. se/Environmental-objectives-and-cooperation/ Swedens-environmental-objectives/Milestonetargets/

Naturvårdsverket (2019d). Inrätta kommunala naturreservat: Vägledning och information om bidrag för att inrätta kommunala naturreservat, retrieved 2019-11-20, http://www.naturvardsverket.se/Stod-imiljoarbetet/Vagledningar/Skyddad-natur/ Naturreservat/Inratta-kommunalanaturreservat/

Naturvårdsverket (n.d). Sveriges friluftsmål, retrieved 2019-09-26, http://www. naturvardsverket.se/Miljoarbete-i-samhallet/ Miljoarbete-i-Sverige/Uppdelat-efter-omrade/ Friluftsliv/Friluftsmalen/

SFS, 1998:808. Miljöbalken. [The Environmental Code].

SFS, 1998:896. Förordning (1998:896) om hushållning med mark- och vattenområden. [Decree (1998:896) about custody with land and water areas]

SFS, 2010:900. Plan och bygglagen [The Planning and Building Act].

Smas, L. and Lidmo, J. (2018). Organising regions: spatial planning and territorial governance practices in two Swedish regions. Europa XXI 35, 21-36. doi.org/10.7163/Eu21.2018.35.2

Sveriges Miljömål (n.d). Sveriges Miljömål, retrieved 2019-11-19, http://www. sverigesmiljomal.se/

Örebro municipality (2018). Vårt framtida Örebro. Översiktsplanen, retrieved 2019-11-20, https://extra.orebro.se/oversiktsplan.4.38aac5 381587bce5d2bf58.html 


\section{European Outlooks references The Netherlands}

Websites

https://aandeslagmetdeomgevingswet.nl/ wetsinstrumenten/gemeente/omgevingsplan/, retrieved 2019-10-05

www.agendastad.nl, retrieved 2019-10-18

www.aorta.nu/wp-content/uploads/2011/02/ Verslag-debatavond-Lunetten.pdf, retrieved 2019-10-18

www.infomil.nl/onderwerpen/ruimte/ruimtelijke/ wet-ruimtelijke/wro-kort, retrieved 2019-10-15

www.omgevingsweb.nl, retrieved 2019-10-15

https://vng.nl/producten-diensten/publicaties/ factsheets/factsheet-ruimtelijke-ordening, retrieved 2019-10-15

https://vng.nl/onderwerpenindex/ruimte-enwonen/omgevingswet/juridische-routekaart/ gemeentelijke-omgevingsvisie, retrieved 201910-21

https://wetten.overheid.nl/BWBRO020449/201807-01, retrieved 2019-10-16

https://zoek.officielebekendmakingen.nl/ stcrt-2016-69729.html, retrieved 2019-10-18

\section{Literature:}

Gemeente Utrecht (2019). Ontwikkelperspectief Maarschalkerweerd (concept for consultation).

Ministerie van Infrastructuur en Milieu (2012). Structuurvisie Infrastructuur en Ruimte. 2012

Ministerie van Infrastructuur en Milieu (2016). Aanpassen met ambitie. Nationale klimaatadaptatiestrategie 2016.

Ministerie van Landbouw, Natuur en Voedselkwaliteit (2014). Rijks Natuurvisie

\section{Germany}

Blotevogel, H.H., Danielzyk, R., and Münter, A. (2014). Spatial Planning in Germany: Institutional Inertia and New Challenges. In M. Reimer, P. Getimis, and H.H. Blotevogel (Eds.), Spatial planning systems and practices in Europe: A comparative perspective on continuity and changes (pp. 83-108). New York, NY: Routledge.

Bläser, K., Danielzyk, R., Fox-Kämper, R., Funke, L., Rawak, M., Sondermann, M. (2012). Urbanes Grün in der integrierten Stadtentwicklung. Strategien, Projekte, Instrumente.

Düsseldorf: Ministerium für Bauen, Wohnen, Stadtentwicklung und Verkehr des Landes Nordrhein-Westfalen.

Bundesinstitut für Bau, Stadt-und Raumforschung (BBSR) (2012). Raumordnungsbericht 2011. Bonn.

Münter and Reimer (2017). ESPON COMPASS Questionnaire One - Germany, unpublished report.

Schmitt, P. and Rickegård, A. (2015). En gigantisk utmaning - strukturell förändring och stadsomvandling i Ruhrområdet [A gigantic challenge - structural and urban change in the Ruhr]. PLAN 1/2015, pp. 30-35.

Scholl, B., Elgendy, H., and Nollert, M. (2007). Raumplanung in Deutschland - formeller Aufbau und zukünftige Aufgaben =: Spatial planning in Germany - formal structure and future tasks. Schriftenreihe des Instituts für Städtebau und Landesplanung, Universität Karlsruhe (TH): Vol. 35. Karlsruhe: Univ.-Verl. Karlsruhe. 



\section{(1I) Nordregio}

P.O. Box 1658

SE-111 86 Stockholm, Sweden

nordregio@nordregio.org

www.nordregio.org

www.norden.org

ISBN: 978-91-87295-84-3

ISSN: 1403-2503

DOI: doi.org/10.6027/R2O20:3.1403-2503 